\title{
Do Employers Support Immigration?
}

\author{
Yuji Tamura \\ TEP Working Paper No. 1107
}

October 2007

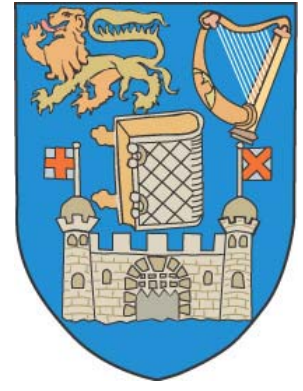

Trinity Economics Papers

Department of Economics

Trinity College Dublin 


\title{
Do Employers Support Immigration?*
}

\author{
Yuji Tamura ${ }^{\dagger}$
}

October 1, 2007

\begin{abstract}
This paper examines whether or not being an employer was an important determinant of individual preferences for immigration restriction in the EU member states in the eve of the 2004 enlargement. Our results do not confirm that employers were more pro-immigration than the rest by expecting a reduction in the cost of labor except in the following sector: sanitation-related activities such as refuse disposal and recreational, cultural and sports activities. On the contrary, we find that employers were more likely to be anti-immigration than the rest in sectors where foreign workers were highly present, such as household activities, construction, wholesale, hotels and restaurants.
\end{abstract}

Key words: individual attitudes toward immigration, employer, EU JEL classifications: F22, J23

${ }^{*}$ I received useful suggestions from Nikolaus Wolf, Mike Harrison and Mike Devereux. All remaining errors are mine.

†yuji.tamura@anu.edu.au; fax.+61 26125 0182; Economics Program, Research School of Social Sciences, Australian National University; Institute for International Integration Studies, Trinity College Dublin 


\section{Introduction}

Employers in developed countries are often thought to benefit from labor immigration. If this were in fact the case, we would expect them to be more supportive of immigration than the rest. The literature on individual attitudes toward immigration has not paid attention to employers so far. This paper attempts to fill this gap. We examine the data on individuals in the European Union member states from Round 1 of the European Social Survey (ESS hereafter) that was conducted during the pre-2004 enlargement period.

The view that immigration is economically beneficial for employers is very common. For instance, Richard Layard at London School of Economics wrote a couple of years before the enlargement, "For European employers ..., unskilled immigration brings real advantages. It provides labour for their restaurants, building sites and car parks and helps to keep these services cheap by keeping down the wages of those who work there." ${ }^{1}$ See also Solé and Parella (2003) who describe why employers would prefer immigrant workers to native workers in Spain.

While this economic logic makes us believe that employers are in favor of more liberal labor immigration, it has not been empirically examined whether or not the status of being an employer makes a difference in terms of preferences for immigration restriction. The literature on individual attitudes toward immigration has so far examined two channels through which immigration is thought to affect people economically in the host countries. One is

\footnotetext{
${ }^{1}$ A letter to Financial Times "Conflict between Europe and immigrant workers" published on 15 May 2002
} 
the factor market, and the other is the welfare state. ${ }^{2}$ The influence of labor market effects of immigration on individual attitudes has been examined by Espenshade and Hempstead (1996), Citrin et al. (1997), Bauer et al. (2000), Scheve and Slaughter (2001), Dustmann and Preston (2004), Mayda (2006) and O'Rourke and Sinnott (2006). However, the main focus has been on attitudes of native labor suppliers. Individual attitudes on the demand side of the labor market have probably been thought too obvious to be studied so far.

Our results do not confirm that employers were more pro-immigration than the rest by reasoning that immigration would reduce the cost of labor. Exceptions are sanitation-related activities such as sewage and refuse disposal and recreational, cultural and sports activities. In these sectors, we find that employers were less likely to prefer immigration restriction than the rest among those who anticipated a wage fall due to immigration. In Austria, employers were more pro-immigration than the rest, but we do not confirm that this is due to the wage effect of immigration.

We also find that, contrary to our expectation, employers were more, rather than less, likely to be anti-immigration than the rest in sectors where foreign workers were highly present, such as household activities, construction, wholesale, hotels and restaurants.

The next section derives hypotheses by using a simple model. Section 3 describes the data. Section 4 presents results. Section 5 concludes.

\footnotetext{
${ }^{2}$ The influence of public finance effects of immigration on individual preferences were examined by Espenshade and Hempstead (1996), Citrin et al. (1997), Dustmann and Preston (2004), Hanson, Scheve and Slaughter (2005) and Facchini and Mayda (2006).
} 


\section{Theory}

Consider a sector with $N>0$ identical producers. The output by each producer is characterized by the following constant-returns-to-scale production function:

$$
q(l, k) \equiv l^{\alpha} k^{1-\alpha}
$$

where $l$ and $k$ denote labor and capital, respectively, and $\alpha \in(0,1)$. In the short run, $k>0$ is fixed. With $r$ denoting the unit price of capital, $r k$ is the fixed cost.

A perfectly competitive firm takes prices as given in maximizing its profit, i.e.,

$$
\max _{l} \pi(q(l), l) \equiv p q(l)-w l-r k
$$

where $p$ and $w$ are the unit prices of output and labor, respectively. ${ }^{3}$ The first-order condition is

$$
q^{\prime}\left(l^{\star}\right)=w / p
$$

where $l^{\star}$ denotes the optimal amount of labor. By rearranging this equation, we get the following short-run factor demand:

$$
l^{\star}(p, w)=k(\alpha p / w)^{\frac{1}{1-\alpha}}
$$

\footnotetext{
${ }^{3}$ To ensure that the producers are operating in the market, we assume that $\pi\left(l_{0}\right) \geq-r k$, or equivalently $p \geq w l_{0} / q\left(l_{0}\right)$, holds with $l_{0}>0$ denoting the labor input per producer without immigration.
} 
By substituting this into the production function (1), we get the following supply function:

$$
q^{\star}(p, w) \equiv k(\alpha p / w)^{\frac{\alpha}{1-\alpha}}
$$

Suppose the sector is open, and the production in the country does not affect the output price in the world. However, the wage is determined in the national labor market.

With $N$ identical producers, the sectoral demand for labor in the country is $N l^{\star}$. Each worker supplies one unit of labor inelastically, and there are $L>0$ sector-specific workers in the country. In equilibrium, $N l^{\star}=L$ or equivalently

$$
w^{\star}(N, L) \equiv \alpha p(N k / L)^{1-\alpha}
$$

which suggests that the wage is decreasing in labor supply and increasing in the number of producers.

By substituting the supply function (5), the labor demand (4) and the equilibrium wage (6), we get

$$
\pi^{\star}(N, L) \equiv(1-\alpha) p l^{\star \alpha} k^{1-\alpha}-r k
$$

where $l^{\star}=L / N$. The first term is the sum of the first and the second terms in (2), which simply indicates that a fraction $\alpha$ of the total revenue is distributed to workers.

The profit function (7) suggests the following: 
- Employers are more pro-immigration than the rest ceteris paribus because profit is increasing in the supply of labor: $\partial \pi^{\star} / \partial L>0$.

This is the main logic behind the argument that immigration would benefit employers. Note, for some producers/sectors, immigration may not increase $L$ perhaps because migrant labor is not useful input in production. Then, $\partial \pi^{\star} / \partial L>0$ is irrelevant. ${ }^{4}$

Equation (7) also suggests the following:

- Employers are less pro-immigration than the rest ceteris paribus because profit is decreasing in the number of employers: $\partial \pi^{\star} / \partial N<0$.

Thus, if immigrants increase the number of producers, employers would oppose such an inflow into the country. In Section 4, we find some evidence to suggest employers' concern with this negative effect.

\section{Data}

ESS Round 1 was conducted during the period 2002-2003. ESS is a biennial survey that covers more than 20 countries in Europe. The target population of each country consists of all persons at the age of 15 or over who reside in the country. The survey consists of core and rotating modules, and one of Round 1's two rotating modules is dedicated to revealing individual opinions about immigration-related issues by using almost 60 questions. This immigration module was framed by giving each respondent the following introduction:

\footnotetext{
${ }^{4}$ However, migrants might increase the third factor by being input for the production of that factor. In such a case, they would indirectly benefit employers.
} 
"People come to live in [the country where the respondent was questioned] from other countries for different reasons. Some have ancestral ties. Others come to work here, or to join their families. Others come because they're under threat. Here are some questions about this issue." ${ }^{5}$

We concentrate on the then member countries of the European Union. By restricting the set of observations to these countries, and by focusing on individual preferences with respect to the immigration from poorer countries of Europe, ${ }^{6}$ we implicitly examine the determinants of individual attitudes in the pre-enlargement European Union toward immigration from countries that were about to join the Union on May 1, 2004.

\subsection{Dependent variable}

Our dependent variable indicates whether each respondent had a preference for immigration restriction. We are interested in individual attitudes in the pre-2004 enlargement European Union toward immigration from the countries that were about to join the Union. The variable is hence based on the responses to the following question: ${ }^{7}$

- To what extent do you think [the country where the respondent was questioned] should allow people from poorer countries in Europe to come and live here?

\footnotetext{
${ }^{5}$ By the use of "live", the permanency of immigrants' stay is deliberately made ambiguous. See Chapter 3 (Part 1) of the ESS Round 1 2002/2003 Technical Report (Edition 2, June 2004) for the aim and outline of the immigration-related questions. We used Edition 6.0 of the data set that was released at http://ess.nsd.uib.no on 19 December 2006.

${ }^{6}$ See the following subsection about the dependent variable, anti.

${ }^{7}$ The ten countries that joined the Union in 2004 had both GDP and GNP per capita lower than any EU15 country according to World Bank's World Development Indicators. The exception is Malta.
} 
Each respondent was asked to choose one of the following 4 ordered categories: "none", "a few", "some" and "many". We collapse these to create a binary variable, anti, that indicates a preference for immigration restriction, i.e., for individual $i$,

$$
\text { anti }_{i}= \begin{cases}1 & \text { if she/he chose either "none" or "a few" } \\ 0 & \text { otherwise. }\end{cases}
$$

\subsection{Explanatory variables}

The main explanatory variable of interest is a dummy variable that is equal to 1 if a respondent employed at least one person including her-/himself and 0 otherwise. $^{8}$ We call this variable employ. According to Section 2, employers would be less likely to prefer immigration restriction if immigrants were perceived to increase the supply of labor. They would be more likely to prefer immigration restriction if immigrants were perceived to increase the number of producers.

Figure 1 shows the distributions of respondents with employ $=1$ and those with employ $=0$, respectively, over the 4 ordered categories on which our dependent variable is based. It implies that employers were more, rather than less, restrictive than the others, regarding immigration from poorer

\footnotetext{
${ }^{8}$ Question F13 of ESS asked "How many employees do or did you have?" to those who chose "selfemployed" in Question F12. Although the respondents were supposed to be filtered by Question F12 in this way, we found some respondents who recorded a positive number of employees in F13 but did not chose "selfemployed" in F12. Question F12 asked each respondent to choose either "an employee", "selfemployed" or "working for your own family's business" that best described her/his status in her/his main job. If the respondent was not working at the time of the interview, the question was asked about her/his previous job. We did not exclude those non-selfemployed employers. That is, employ $=1$ if a respondent either chose "selfemployed" in F12 or recorded a positive integer in F13, or both.
} 
countries in Europe.

[Figure 1 about here]

ESS allows us to distinguish between employers by the number of employees. Figure 2 shows the distributions of respondents who employed only themselves and those who did not employ themselves, respectively, over the 4 ordered categories on which our dependent variable is based. It suggests that those who employed only themselves were even more likely to prefer immigration restriction than the rest, compared to Figure 1. However, Figure 3 indicates that there was not much difference between those who employed at least one person other than themselves and the rest.

[Figures 2 and 3 about here]

These pictures motivate regression analysis to control factors affecting individual attitudes other than the status of being an employer. For example, Table 1 shows that more of those with employ $=1$ are distributed to low levels of education, compared to the distribution for the whole sample. The same table also indicates that those who employed only themselves are responsible for this observation. On the other hand, less of those who employed at least one person other than themselves seem to be distributed to low levels of education, compared to the distribution for the whole sample. Hence we create 4 dummy variables (ed0 to ed3) to control for each 
respondent's level of education. ${ }^{9}$

[Table 1 about here]

We also find that those who employed at least one person other than themselves were richer than the others. ESS collected each respondent's estimate of net household income in 12 ordered categories. The categories do not share an equal interval. We assign the mid-value of each category's income range to the respondents in that category. ${ }^{10}$ We then divide each figure by the corresponding number of household members because we examine the importance of economic self-interest to individual attitudes. This yields net income per capita assuming, although unrealistic, that household income is shared equally by the members. We finally divide each figure by the corresponding national mean net income per capita. We call this variable relinc, approximating the relative income position of each respondent in the country where she or he was interviewed.

The sample mean of relinc is 1.075. However, the mean for those with employ $=1$ is higher than the rest (1.243 and 1.050, respectively). The

\footnotetext{
${ }^{9}$ ESS sorted respondents into 7 groups according to a modified version of ISCED97, as in Table 1. We collapse these into 4 groups by merging "primary or basic (first stage)" and "lower secondary or basic (second stage)"; "upper secondary" and "postsecondary (non-tertiary)"; and "tertiary (first stage)" and "tertiary (second stage)". The data for Austria are missing in the cross-country data file due to a slight inconsistency in the data collection between the country and the rest. We used the corresponding data in the Austria-specific file by merging "abschluss weiterbildende schule" and "matura".

${ }^{10}$ The highest category has no upper bound and hence no mid-value. We used the following formula for the mid-value of the highest category: the largest figure for the second highest category + (the largest figure for the second highest category - the largest figure for the third highest category)/2. The data for France and Ireland are missing in the cross-country file due to a slight inconsistency in the data collection between these countries and the rest. However, this should not matter, for our measure is of relative income at the national level. Hence we used the corresponding household income data from country-specific files for France and Ireland.
} 
difference stems from the gap between those who employed at least one person other than themselves and the rest. While we find little difference between the means for those who employed only themselves and the others (1.050 and 1.077, respectively), ${ }^{11}$ the figure for those who employed at least one person other than themselves is much higher than the figure for the rest (1.534 and 1.050 , respectively). ${ }^{12}$

We speculate that immigrant labor is more employable in some sectors than others due to the nature of production. If immigrant labor were more employable, employers would benefit from an increase in labor supply due to immigration. In order to differentiate observations by the sectoral employability of immigrants, we create a measure that approximates the relative extent of the sectoral employment of foreign workers in each country. By using Eurostat Census 2001, we compute the share of foreigners in each sector's total employment in a country, divided by the share of foreigners in that country's total employment. Table 2 presents the obtained figures. ${ }^{13}$ A figure greater than 1 indicates that the share of foreigners in the corresponding sector's employment is relatively high in the country. We assume that this indicates a relatively high employability of immigrant labor in the sector. ${ }^{14}$ Unfortunately, the corresponding Belgian data are missing in the source.

\footnotetext{
${ }^{11}$ The 95 percent confidence intervals for these figures overlap each other.

${ }^{12}$ The figures are computed using the sample after listwise deletion, i.e., the observations actually used for regression.

${ }^{13}$ OECD has produced a similar table in its annual publication, International Migration Outlook (formerly Trends in International Migration), but it does not give the figures as we do in our table.

${ }^{14}$ However, this assumption may not be valid in some countries. Even in a sector where foreign workers are highly employable, we may observe a low value of $i s b$ because of, for instance, strict national policy regarding the issuance of work permits. We discuss this possibility further in the conclusion.
} 
[Table 2 about here]

Not surprisingly, in all 14 countries, the hotel and restaurant sector employed many foreign workers (category h). Another sector with a relatively high proportion of foreigners is of household activities (category p), e.g., housemaids. In the other sectors, however, we see variations across the countries. We also notice that the required skills in sectors with a high proportion of foreign workers vary considerably. For instance, while the construction sector (category f) hired many foreign workers in more than half the countries, they also seem to have been highly present in the education sector (category $\mathrm{m}$ ) in Finland and the health and social service sector (category n) in the United Kingdom.

ESS collected a two-digit NACE Rev.1 code for each respondent, and hence we know to which NACE Rev.1 major group he or she belonged. ${ }^{15}$ We assign the relevant figure in Table 2 to each ESS respondent. ${ }^{16}$ We call this variable $i s b$. We removed observations that belonged to extraterritorial organizations (category q). The sector should naturally employ many foreigners, and Table 2 confirms that in 5 countries. The exclusion of the observations should remove outliers, for the proportion of those who belonged to such an organization in each country is very low: the highest is .013 in France.

\footnotetext{
${ }^{15}$ Note that the coding was based on each respondent's answer to ESS Question F24: What does or did the firm or organization you work or worked for mainly do or make? Since a respondent could give an answer based on the past work, the respondents without a NACE Rev.1 code are not identical with the unemployed.

${ }^{16}$ This variable is similar to what Mayda (2006: Table 3A, Specifications 11 and 12) constructed at the occupation level. We use sector rather than occupation because our focus is on employers, not employees.
} 
The sample mean of $i s b$ is .988 . We find that the figure is slightly higher for employers than the others (1.057 for employ $=1$ and .978 for the rest). However, there is little difference between the means for those who employed only themselves and the rest (1.024 and .985, respectively). ${ }^{17}$ We find that those who employed at least one person other than themselves were on average in sectors with a high proportion of foreign workers (1.107 for those who employed at least one person other than themselves and .982 for the rest).

Other explanatory variables include purely exogenous variables such as a respondent's gender (female) and approximate age in years at the time of interview. We also have an indicator of whether or not at least one parent of a respondent was born abroad (fparent); the respondent belonged to an ethnic minority in the country where the interview took place (ethnic); and he or she was a citizen of that country (citizen).

A respondent's closeness to immigrants is approximated by the number of immigrant friends she or he had (friend dummies). In addition, we use a measure of a respondent's exposure to the media on current affairs and politics (media) in hours per weekday. ${ }^{18}$ The media is often thought to influence one's view, and we want to control for such potential influence. Since the status of being unemployed has been found an important determinant

\footnotetext{
${ }^{17}$ The 95 percent confidence intervals for these figures overlap each other.

${ }^{18}$ We created this variable by using the responses to the 3 separate questions: On an average weekday, how much of your time is spent watching television (ESS Question A2) / listening to the radio (A4) / reading newspapers (A6) about politics and current affairs? The responses to these questions were given on the same scale that has an equal interval in hours between categories. This enables us to easily aggregate the responses at the individual level.
} 
of individual attitudes toward immigration, ${ }^{19}$ we also control for it by using a dummy variable that is equal to 1 if a respondent was unemployed and wanting a job in the last seven days and 0 otherwise. ${ }^{20}$ We call this variable unemploy.

Finally, we control for race/ethnicity-based discrimination attitudes. To do this, we use the responses to the following two questions:

- To what extent do you think [the country where the respondent was questioned] should allow people of the same race or ethnic group as most of the people in the country to come and live here?

- To what extent do you think [the country where the respondent was questioned] should allow people of a race or ethnic group different from most of the people in the country to come and live here?

These questions ask the same except the race or ethnic group of migrants. Therefore, any difference between the responses within a respondent should pick up his/her discrimination based on race or ethnicity. For each question, a response is one of "none (coded as 0)", "a few (1)", "some (2)" or "many (3)". We subtract the response to the second question from that to the first question for each respondent. Hence the higher the number we obtain, the more discriminating against different races and ethnic groups. ${ }^{21}$ We call this variable racist.

\footnotetext{
${ }^{19}$ See for example O'Rourke and Sinnott (2006).

${ }^{20}$ We included both those who indicated that they were actively looking for a job (uempla $=1$ in ESS Question F8a) and those who indicated that they were not actively jobhunting but wanting a job (uempli $=1$ in the same question). We are not primarily interested in attitudes of the unemployed, but we include this variable to increase the goodness of fit.

${ }^{21}$ This way of taking the difference is inappropriate, for the response categories are only ordered. In other words, the magnitude of an estimated coefficient is not meaningful. Our
} 
Table 3 provides summary statistics for our variables. Due to a lack of information on $i s b$, we exclude Belgium from the EU15 countries in our main data analysis.

[Table 3 about here]

\section{Results}

We estimate probit specifications by maximum likelihood. The benchmark model is

$$
\operatorname{Pr}(\text { anti }=1 \mid \text { employ }, \mathbf{x})=\Phi\left(\alpha+\beta e m p l o y+\mathbf{x}^{\prime} \boldsymbol{\gamma}\right)
$$

where $\Phi(\cdot)$ is the standard normal CDF. We are interested in $\hat{\beta}$ 's contribution to the probability.

We present marginal effects in terms of probability evaluated at the mean of each explanatory variable. For a binary explanatory variable, the figure is the probability difference between observations with the variable equal to 1 and those with the variable equal to 0 . Estimated standard errors are based on the assumption that observations are not necessarily independent within each region of a country, but are independent across regions of the country. ${ }^{22}$

aim is to control for race/ethnicity-based attitudes of respondents and see the direction of influence, e.g., Agresti (2002).

${ }^{22}$ Since the probit-estimated conditional mean function is inconsistent when there is heteroskedasticity, reporting robust standard errors does not solve the problem of variation in the variance. One way to tackle this is to model the variance as a function of covariates, e.g., Wooldridge (2002: 463-465). However, we do not report our results from such probit models because the results changed dramatically by using different sets of covariates in modelling the variation in the variance. It was unclear a priori which set of 
Table 4 presents the benchmark result for the Union as well as each member state except Belgium. ${ }^{23}$ The variable of our main interest is employ. We find that the status of being an employer is not statistically significant at the Union level. However, it is so for four countries. Employers were less likely to prefer immigration restriction than the others only in Austria: the probability of being restrictive is lower for employers than the rest by about .2. For the Netherlands, Sweden and the United Kingdom, the estimated probability difference is positive, although the size is small ranging from .065 in Sweden to .080 in the UK.

[Table 4 about here]

Turning to the other variables, the estimated marginal effect of $i s b$ also has different signs across the countries. It is significantly positive for Germany, Greece and Luxembourg and is negative for Finland and the UK. However, it is significant not only statistically but also in size only for Luxembourg where an increase in the sectoral employability of foreign workers by .1 is related to an increase in the probability of being restrictive approximately by .02 . The marginal effect of $i s b$ is not statistically significant at the Union level.

The estimated effect of unemploy suggests that the unemployed were in general more likely to support immigration restriction than the rest: the probability of being anti-immigration is higher for the unemployed than the variables should be used in modelling the variation, for different sets of variables passed the significance test.

${ }^{23}$ In the EU probit, we include 13 country dummies, although the corresponding estimates are not reported in the following tables due to a lack of space. 
others by about .1 at the Union level, although this is true at the country level only for Germany, Finland and Italy. This might suggest that the unemployed were more worried about the labor market effect of immigration than the rest. This finding is consistent with O'Rourke and Sinnott (2006), but Bauer et al. (2000) found that the status of being unemployed was not an important determinant.

The exposure to the media on current affairs and politics seems to reduce the probability of preferring immigration restriction: the sign of the estimated marginal effect of media is significantly negative at the Union level. At the country level, it is significantly negative for Germany, Denmark, France and the UK. For instance, an additional hour spent on the media is related to a decrease in the probability of being restrictive by about .03 in France and the UK. The reason for the negative effect might be because longer exposure to the media on current affairs and politics increases the chance of knowing various perspectives on the subject, resulting in less biased opinions.

The relative income position does not seem to be an important determinant of individual attitudes toward immigration: the estimated marginal effect of relinc is significantly negative only for Portugal but at 10 percent.

We find that more educated persons are less likely to prefer immigration restriction except for Spain and Portugal where the effect of education is not statistically significant. A higher level of education seems to make people more liberal. This confirms the findings by Hainmueller and Hiscox (2007). ${ }^{24}$

\footnotetext{
${ }^{24}$ Scheve and Slaughter (2001) and Mayda (2006) show that this implies native workers' concern with the labor market impact of immigration, consistent with the H-O model.
} 
As we expected, the more immigrant friends the respondent had, the less likely to be anti-immigration she or he was except in Luxembourg where the effects of friend dummies are not statistically significant. Note that the proportion of non-nationals is very high in Luxembourg compared to the other countries: hence the number of immigrant friends may not pick up the closeness to immigrants as good as it does in the other countries.

Discrimination against minority races increases the probability of preferring immigration restriction in most of the countries. The effect of racist is significantly positive also at the Union level. This seems to extend Dustmann and Preston's (2004) finding about the UK to other EU countries.

Being a citizen of the country is associated with a higher probability of preferring immigration restriction than otherwise in Germany, Spain, Finland, Greece and Ireland. The effect of citizen is significantly positive also at the Union level.

The estimated effect of ethnic is mixed across the countries. Belonging to an ethnic minority group in the country is associated with a lower probability of being anti-immigration than otherwise in Spain, Finland, Greece and Luxembourg, but with a higher probability in Austria and Italy. The magnitude of the effect is large for Italy. The effect of ethnic is not statistically significant at the Union level, however.

Having at least one parent who was born outside the country is associated with a lower probability of being restrictive than otherwise in France, Greece and the Netherlands. This is also the case at the Union level. Scheve and Slaughter (2001) for instance found that immigrants and their children were less restrictive than the rest in the US. 
Females were less likely to be anti-immigration than males in Germany, Denmark, Finland, Greece and Ireland. However, the effect of female is not statistically significant at the Union level.

The older the respondent was, the more likely to be restrictive he or she was in Austria, Germany, Denmark, Finland, France and Greece. This is also the case at the Union level. This confirms the findings by other studies, e.g., O'Rourke and Sinnott (2006).

[Table 5 about here]

Immigrant labor may be useful input for some, but not all, sectors in a host economy. In Table 5, we interact employ with our measure of the sectoral employability of immigrant labor. We expect the marginal effect of this interaction term to be negative. That is, we expect employers to be less restrictive in sectors where the employability of foreign workers is relatively high in the country. We also interact unemploy with isb to examine whether its marginal effect is positive. That is, native workers are more likely to compete with immigrants in sectors where the employability of foreign workers is relatively high in the country. The addition of these two interaction terms worsens the fitness only for Ireland. For most of the other countries, the three goodness-of-fit measures increase. However, the results are not necessarily consistent with our expectation.

We find the marginal effect of employ $\times i s b$ significantly negative only in Luxembourg. Its size relative to the significantly positive effect of employ implies that, as far as the sectoral employability of immigrant labor was as 
high as the national average, i.e., $i s b \geq 1$, employers were less likely to be restrictive than the rest. In sectors where $i s b$ was low, employers were more likely to be restrictive than the rest. One possible explanation for the latter is that immigration can make them less competitive in the output market than those employers who could benefit from cheap labor. Therefore, this Luxembourg case is consistent with our expectation.

In Spain and the UK, however, we find the marginal effect of employ $\times i s b$ significantly positive. For Spain, its size relative to the significantly negative effect of employ implies that, as far as the employability of immigrant labor does not exceed the national average, employers remain supportive of immigration than the rest. This might suggest that $i s b$ is not a measure of the sectoral employability of immigrants. A low value of $i s b$ might be for instance just a consequence of restrictive immigration policy in place at the time. If so, a low value of $i s b$ in a sector might be a sign of labor shortage in that sector, and the employers may desire increased immigration.

The effect of employ is significantly negative in Austria and positive in Finland and Sweden. It does not seem to depend on $i s b$ in these countries. Also note that neither employ nor employ $\times i s b$ is an important determinant at the Union level.

Turning to the status of being unemployed, the estimated marginal effect of unemploy $\times i s b$ is significantly positive in Italy and Luxembourg. In both countries, the effect of unemploy is significantly negative. Therefore, the status of being unemployed increases the probability of preferring immigration restriction if the sectoral employability of immigrant labor is sufficiently high: $i s b \geq .6$ for Italy and $i s b \geq .4$ for Luxembourg. 
The marginal effect of unemploy $\times i s b$ is significantly negative in Germany, Spain and the UK. For the former two countries, the effect of unemploy is significantly positive, suggesting that the unemployed were more restrictive than the rest in sectors where the share of foreign workers in employment is relatively low. This might be due to the fear of being invaded rather than already realized penetration by immigrant workers.

At the Union level, the effect of unemploy is significantly positive as in Table 4 , but the magnitude is larger. The marginal effect of unemploy $\times i s b$ is not statistically significant.

The results for the other explanatory variables remain almost the same as in Table 4 .

[Tables 6(a) and 6(b) about here]

The results in Tables 4 and 5 confirmed our expectation about the effect of employ only in a few countries, while we found counter evidence in a few other countries. At the Union level, the status of being an employer does not seem to matter to individual preferences for immigration restriction. This could be due to the fact that employers had different opinions about the economic impact of immigration, while the assumption for deriving the hypotheses is that employers anticipate immigration to reduce the cost of labor by increasing labor supply.

In order to control for the perception of the economic impact of immigration, we split the sample into two such that, within each subsample, 
respondents shared a similar opinion about immigration's impact on the cost of labor. ESS Round 1 contains responses to the following statement: ${ }^{25}$

- Average wages and salaries are generally brought down by people coming to live and work here.

One group consists of respondents who chose either "agree" or "strongly agree" with the statement, and the other group consists of the remaining non-missing respondents. By controlling for this subjective perception, we find that the results change. In Table 6(a), we presents the results by re-estimating the specification of Table 4 only for those who thought that immigration would have a negative effect on wages. Table 6(b) presents the results for those who did not think so.

In Table 6(a), we find the effect of employ statistically insignificant except for Austria where it is negative. The magnitude is similar to the one we found in Table 4. The other estimates suggest that the status of being an employer did not make a difference to individual preferences for immigration restriction in most of the countries even in a group of people who expected immigration to reduce the cost of labor. (In addition, we find later in Table 6(b) that, in Austria, the effect of employ is significantly negative also among those who did not expect immigration to reduce wages, suggesting that the negative effect of employ in the country does not support our theoretical reasoning.)

Turning to the other variables, there is now only one country for which the effect of unemploy remains significantly positive, i.e., Italy. However,

\footnotetext{
${ }^{25}$ Question D18
} 
the effect of unemploy remains significantly positive at the Union level. The marginal effect of $i s b$ is still significantly positive for Greece and Luxembourg, but no longer significant for Germany. Instead it is significantly positive for Austria. It is now significantly negative for Ireland, but no longer significant for Finland and the UK. The result is thus mixed. The marginal effect of relinc is significantly positive for Portugal and Sweden. Note that it was negative only for Portugal in Table 4.

As for the effect of education, we still find that a higher attainment is related to a lower probability of being anti-immigration. However, we also note that educational attainment is not important for more countries than in Table 4, namely, Austria, Spain, Ireland, Italy, Luxembourg and Sweden. We find that the exposure to the media is not an important determinant at all in this subsample, while its marginal effect was significantly negative at the Union level as well as for some countries in Table 4. The effect of having immigrant friends continues to be generally negative, and the magnitude is increasing in the number of such friends. But we also note that it is not significant for more countries than in Table 4, i.e., Greece, Luxembourg, Sweden and the UK. Surprisingly, the effect of racist is significantly negative for Spain (i.e., the more racist a respondent was, the less restrictive he or she was in Spain), although it remains generally positive for others.

The effect of citizen is no longer significant at the Union level. Neither for Ireland. It becomes significantly positive for Luxembourg, while it is not only significant but also negative for Denmark. The effect of belonging to an ethnic minority group in the country now seems negative, while it was mixed signwise in Table 4 . The effect of having at least one parent born 
overseas continues to be significantly negative at the Union level. However, we now find that it is positive for Austria and Spain. The effect of female is now significantly positive for France and Italy, while it was negative for countries where it was statistically significant in Table 4 . This may be intuitive: females are generally disadvantaged in the labor market, so the effect of female is positive among those who anticipate a negative labor market impact of immigration. The marginal effect of age remains generally positive, although it is now negative for Ireland and the Netherlands.

Table 6(b) reports the results for the subsample of those who did not think that immigration would depress wages. The results are somewhat different from Table 6(a). The effect of employ continues to be significantly negative for Austria. We observe that the magnitude is larger than that for those who thought that wages would fall due to immigration. This seems to suggest that the source of benefit from immigration is not its wage effect in the country, and it does not support our theoretical reasoning. The effect of employ is significantly positive for Spain, Sweden and the UK. It is also significantly positive at the Union level. Since we did not find a significantly positive effect of employ in Table 6(a), the positive effect of employ comes from those employers who did not think that immigration would reduce wages. This seems to suggest that there is not benefit but some disadvantage of immigration for employers, e.g., they increase the number of producers.

The effect of unemploy is no longer significant except for the Netherlands where it is significantly negative but only at 10 percent. This, together with the estimate in Table 6(a), appears consistent with what we would expect: 
the unemployed would be against immigration if they anticipate immigration to affect their labor market negatively, further reducing the employment prospect. The marginal effect of $i s b$ is significantly positive for Germany, Luxembourg and the Netherlands. But it is negative for Finland. Note that the marginal effect of $i s b$ was significantly positive for Luxembourg also among those who expected immigration to reduce wages: see Table 6(a). The marginal effect of media is generally negative except for Italy where it is significantly positive. The media seems to have a pro-immigration effect among those who did not anticipate a wage fall due to immigration, while it was found insignificant among those who expected immigration to induce a wage reduction.

The marginal effect of relinc is not statistically significant except for Greece where it is negative at 10 percent. A higher educational attainment continues to be associated with a lower probability of being anti-immigration, although the educational attainment dummies are not statistically significant for Austria, Spain and Luxembourg. Since the education dummies were insignificant for these countries also in Table 6(a), we might conclude that education is not an important determinant of individual attitudes toward immigration in these countries once we control for the subjective perception of the impact of immigration on wages.

The effect of having immigrant friends remains generally negative, and the magnitude is increasing in the number of such friends, except for Italy and Luxembourg where it is statistically insignificant. Note that, for Luxembourg, the effect of having immigrant friends was insignificant also in Table 6(a). The effect of racist is positive. So is the effect of citizen: in particular 
for Greece and Ireland. The effect of belonging to an ethinc minority group does not seem to matter to individual preferences for immigration restriction except for Austria and Italy where it is significantly positive. Since the effect of ethnic was generally negative in Table 6(a), the mixed results we found in Table 4 are thus split signwise by the perception. However, it is counter intuitive. We would expect the effect of ethnic to be positive, rather than negative, among those who anticipate a wage fall due to immigration because immigrants would easily substitute for ethnic minority workers.

The effect of having at least one parent born abroad is mixed: it is significantly negative for Luxembourg and the Netherlands, but positive for Finland and Sweden. The effect of female is negative where it is statistically significant, i.e., Germany, Finland, Greece, Ireland and Sweden. The marginal effect of age is positive where it is statistically significant, namely, Austria, Denmark, Finland and France. It is also significantly positive at the Union level.

[Tables 7(a) and 7(b) about here]

We also re-estimate the specification used for Table 5. Table 7(a) reports the results for those who thought that immigration would depress wages, and Table 7(b) for those who did not think so.

Table 7(a) shows that the marginal effect of employ $\times i s b$ is significantly negative for Luxembourg and Portugal. This is consistent with our expectation that employers are more pro-immigration in sectors where migrant labor is useful input. However, for Austria where the effect of employ is significantly negative, it is positive. It suggests that employers are more likely to 
be pro-immigration in the country unless the sectoral employability of immigrant labor is sufficiently high. Note that the marginal effect of employ $\times i s b$ was found statistically insignificant for the country in Table 5. We find that neither the effect of employ nor that of employ $\times i s b$ is statistically significant at the Union level.

The marginal effect of unemploy $\times i s b$ is significantly positive only for Italy where the effect of unemploy is significantly negative. It suggests that the unemployed were more likely to be restrictive than the rest in sectors with a relatively high proportion of foreign workers. For Spain and France, however, the marginal effect of unemploy $\times i s b$ is significantly negative, and the effect of unemploy is positive, suggesting that, as far as $i s b$ was sufficiently low, the unemployed were more likely to be anti-immigration than the others. This again implies that $i s b$ may not be a good measure of the sectoral employability of immigrant workers in some countries. At the Union level, we find that the unemployed are more likely to be restrictive than the rest regardless of $i s b$, as we found in Table 5 . Note also that the Italian and Spanish results were the same in sign as in Table 5.

The effects of the other explanatory variables remain almost the same as in Table 6(a).

Table 7(b) shows that the marginal effect of employ $\times i s b$ is significantly negative for Finland where the effect of employ is significantly positive. Here the respondents did not think that immigration would depress wages. Hence the source of the negative sign is not due to the wage impact of immigration. Note that the marginal effect of employ $\times i s b$ is significantly positive for Spain. We also find the effect of employ significantly positive for the Netherlands 
and Sweden regardless of $i s b$.

The marginal effect of unemploy $\times i s b$ is significantly positive for Greece where the effect of unemploy is negative. It suggests that the unemployed were more likely to be anti-immigration in sectors where the presence of foreign workers is relatively high in the country. However, for Germany, Spain and the UK, the opposite is the case: as far as $i s b$ is sufficiently low, the unemployed are more likely to be restrictive than the others.

The estimated effects of the other explanatory variables remain almost the same as in Table 6(b).

[Table 8 about here]

We have assumed that a high value of $i s b$ is associated with a high sectoral employability of immigrant labor. However, even in sectors where foreign workers are useful input for production, the presence of foreign workers might be limited because of for instance restrictive policy regarding the issuance of work permits. ${ }^{26}$ In such a case, a lower value of $i s b$ might be associated with less restrictive attitudes, while a high value of $i s b$ might suggest an already sufficient supply of immigrant labor. This might be one reason why the sign of the employer-related terms interacted with $i s b$ is not consistent across the countries.

In order to check whether the status of being an employer makes a difference in each sector assuming that the employability of foreign workers is

\footnotetext{
${ }^{26}$ Although the EU imposes restrictions on its members regarding the admission of workers from non-member countries, the control of immigration from outside the Union largely remains under the domain of national policies. See Boeri et al. (2002: 46).
} 
homogeneous within a sector across the countries, we re-estimate the specification of Table 4 without $i s b$ sector by sector. Due to the limited number of observations, we did not re-estimate for each country but only at the Union level. Note that, by dropping $i s b$ from the list of explanatory variables, Belgian observations become useful. Hence we include Belgium in this estimation. Due to a lack of observations after listwise deletion, we ignore fishing activities (category b) and mining/quarrying activities (category c). Table 8 compares the estimated effects of employ and also unemploy across the NACE Rev.1 major sectors. ${ }^{27}$ The figures in column i are from the full sample, while those in columns ii and iii are from those who thought that immigration would reduce wages and those who did not think so, respectively.

First, we notice that, using the full sample, employers are not particularly more supportive of immigration than the rest in none of the sectors. However, in the household-activity sector (category p), the estimated effect of employ is $10 \%$-significantly positive, implying that employers were more anti-immigration than the rest in that sector. By controlling for the subjective perception of the wage effect of immigration, we find that the statistical significance of the positive effect increases for the sector among both those who expected immigration to decrease wages and those who did not. In addition, the magnitude is larger among those who did not think that immigration would depress wages than those who thought so. What makes employers in the household-activity sector more anti-immigration than nonemployers? In the sample, we find that all employers in this sector employed

\footnotetext{
${ }^{27}$ Due to a lack of space, the full results are not presented. The other estimates are available from the author upon request.
} 
only themselves. Also note that foreign workers were highly present in the sector across countries: see Table 2. If immigrants into this sector also selfemployed themselves, the number of service providers would increase in the sector, intensifying competition in the output, rather than input, market. We will check on this line of reasoning later.

Second, we find that, in the hospitality sector (category h), the probability of preferring immigration restriction is higher for employers than the others among those who anticipated immigration to reduce the cost of labor. This is counter intuitive, given the standard argument exemplified by Lord Layard's letter to the FT in the introduction. Note that the estimated effect of employ is also significantly positive in the construction, wholesale/retail and repairing service sectors (categories $\mathrm{f}$ and $\mathrm{g}$ ) among those who did not think that immigration would depress wages. Categories $\mathrm{f}, \mathrm{g}, \mathrm{h}$ and $\mathrm{p}$ generally employed more foreign workers than in the other categories, as Table 2 shows. It might be that employers had experienced dissatisfaction with the quality of migrant labor they employed. Another possibility is that employers anticipated intensified competition in their output, rather than input, markets due to immigration.

Third, there is only one sectoral category that gives evidence consistent with our expectation, i.e., category o that includes sewage and refuse disposal, sanitation-related activities and recreational, cultural and sports activities. The estimated effect of employ is significantly negative among those who thought that immigration would reduce wages.

When discussing the positive effect of employ in the household-activity sector above, we speculated that the size of an employer in terms of the 
number of employees might affect the impact of immigration which the employer anticipates. Small employers, in particular those who employed only themselves, might not gain from intensified competition in the labor market. Since large employers may gain from it, small employers may even lose because of intensified competition in the output market. In addition, migrants might directly increase the number of producers in some sectors: OECD (2006: 56-58) shows that self-employment among immigrants in those countries has increased since 1999. ${ }^{28}$ Those migrants' small businesses are typically restaurants, cleaning services, groceries and the like (Jandl et al. 2003: $37-40) \cdot{ }^{29}$

Since ESS allows us to distinguish between employers by the number of employees, we re-estimated all the specifications presented above by replacing employ with two variables. In one case, we used a dummy variable, employself which is equal to 1 if a respondent employed only him-/herself and 0 otherwise, together with a variable that records the number of employees excluding him-/herself. In the other case, we used employself and employother which is equal to 1 if the number of employees excluding him/herself is at least one and 0 otherwise. These variables are also summarized in Table 3.

Using these variables instead of employ, we found mixed results across countries as well as across sectors at the Union level. We did not find

\footnotetext{
${ }^{28}$ See Clark and Drinkwater $(1998 ; 2000)$ and Blanchflower and Shadforth (2007) for the trend in the UK.

${ }^{29}$ Menz (2002) describes how companies in high-wage countries took advantage of cheap posted labor of subcontractors in low-wage countries within the Union. This also implies that small self-employed subcontractors would have been competing with foreign labor, while large employers benefited from access to foreign labor.
} 
strong evidence that smaller employers, in particular those who employed only themselves, were more likely to prefer immigration restriction. In Austria, employers were more pro-immigration than the rest regardless of the number of employees. In Portugal, a bigger employer was more, rather than less, likely to prefer immigration restriction. However, we did not find any pattern across sectors at the Union level. ${ }^{30}$

\section{Conclusion}

We examined the importance of being an employer in determining individual preferences for immigration restriction in the EU countries during the period 2002-2003. A simple economic model implies that the immigration of workers would benefit employers in the host country. However, the same model also indicates that employers may oppose immigration when it increases the number of producers. This latter possibility is often ignored in the literature on individual attitudes toward immigration.

Our results from empirical analysis do not confirm that employers were more pro-immigration than the rest because immigration would reduce the cost of labor. Exceptions are sanitation-related activities such as sewage and refuse disposal and recreational, cultural and sports activities. In these sectors, we find that employers were less likely to prefer immigration restriction than the rest among those who anticipated a wage fall due to immigration. Employers were more pro-immigration than the rest in Austria, but we do not confirm that this is due to the wage effect of immigration.

\footnotetext{
${ }^{30}$ The results are not included in the paper but available upon request.
} 
We also find that, contrary to the common expectation, employers were more, rather than less, likely to be anti-immigration than the rest in sectors where foreign workers were highly present, such as household activities, construction, wholesale, hotels and restaurants. We speculate that small employers were responsible for the higher probability of being restrictive among employers than the others in these sectors. Employers are less likely to benefit from access to cheap labor if they are not hiring many workers. But since large employers can benefit from it, small employers would become less competitive in the output market. Thus, immigration might hurt small employers indirectly by making large employers more competitive. However, by using ESS Round 1, we did not find any pattern that depends on the size of employer in terms of the number of employees.

One major weakness of the analysis is that we did not have a reliable measure of the employability of immigrant labor at the sector level in each country. We suspect the main reason why we did not obtain any clear pattern regarding employer $\times i s b$ across the countries is that $i s b$ measures the employability of immigrant labor in some sectors/countries but not in others because immigration policy of each country would distort the flow of foreign labor. Further investigation is necessary with a better measure of the sectoral employability of migrant workers.

In conclusion, it is inappropriate to assume without careful analysis that employers are pro-immigration because of potential benefits which economic theory predicts them to receive. An investigation of the reasons why some employers are more anti-immigration than the others is left for future research. 


\section{References}

Agresti, A., 2002, Categorical Data Analysis, 2nd ed., Wiley

Bauer, T., Lofstrom, M., Zimmermann, K.F., 2000, Immigration policy, assimilation of immigrants, and natives' sentiments towards immigrants: evidence from 12 OECD countries, Swedish Economic Policy Review 7: $11-53$

Blanchflower, D.G., Shadforth, C., 2007, Entrepreneurship in the UK, IZA Discussion Paper 2818, Bonn: Institute for the Study of Labor

Boeri, T., Hanson, G., McCormick, B., eds., 2002, Immigration Policy and the Welfare System, Oxford University Press

Citrin, J., Green, D.P., Muste, C., Wong, C., 1997, Public opinion toward immigration reform: the role of economic motivations, Journal of Politics 59(3): 858-881

Clark, K., Drinkwater, S., 1998, Ethnicity and self-employment in Britain, Oxford Bulletin of Economics and Statistics 60(3): 383-407

Clark, K., Drinkwater, S., 2000, Pushed out or pulled in? self-employment among ethnic minorities in England and Wales, Labour Economics 7(5): 603-628

Dustmann, C., Preston, I., 2004, Racial and economic factors in attitudes to immigration, CReAM Discussion Paper 01/04, Centre for Research and Analysis of Migration, University College London 
Espenshade, T.J., Hempstead, K., 1996, Contemporary American attitudes toward U.S. immigration, International Migration Review 30(2): 535570

Facchini, G., Mayda, A.M., 2006, Individual attitudes towards immigrants: welfare-state determinants across countries, mimeo

Hainmueller, J., Hiscox, M.J., 2007, Educated preferences: explaining attitudes toward immigration in Europe, International Organization 61(2): $399-442$

Hanson, G.H., Scheve, K.F., Slaughter, M.J., 2005, Public finance and individual preferences over globalization strategies, NBER Working Paper 11028, Cambridge, MA: National Bureau of Economic Research

Jandl, M., Kraler, A., Stepien, A., 2003, Migrants, minorities and employment: exclusion, discrimination and anti-discrimination in 15 member states of the European Union, Vienna: European Monitoring Centre on Racism and Xenophobia (http://fra.europa.eu)

Mayda, A.M., 2006, Who is against immigration? a cross-country investigation of individual attitudes toward immigrants, Review of Economics and Statistics 88(3): 510-530

Menz, G., 2002, Patterns in EU labour immigration policy: national initiatives and European responses, Journal of Ethnic and Migration Studies 28(4): $723-742$

OECD, 2006, International Migration Outlook 2006, Paris: OECD 
O'Rourke, K.H., Sinnott, R., 2006, The determinants of individual attitudes towards immigration, European Journal of Political Economy 22(4): $838-861$

Scheve, K.F., Slaughter, M.J., 2001, Labor market competition and individual preferences over immigration policy, Review of Economics and Statistics 83(1): 133-145

Solé, C., Parella, S., 2003, The labour market and racial discrimination in Spain, Journal of Ethnic and Migration Studies 29(1): 121-140

Verbeek, M., 2004, A Guide to Modern Econometrics, 2nd ed., Wiley

Wooldridge, J.M., 2002, Econometric Analysis of Cross Section and Panel Data, MIT Press 
Fig.1 To what extent do you think the country should allow people from poorer countries in Europe to come and live? is

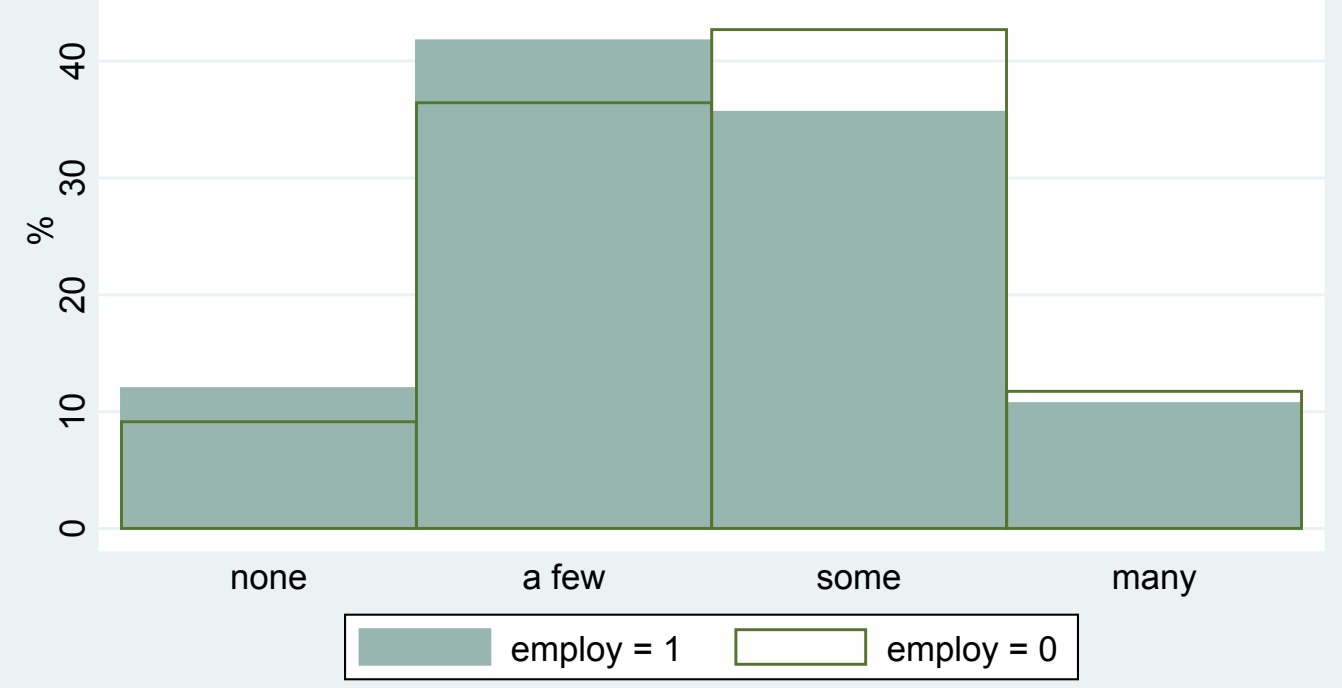

Source: ESS 2002-2003, Round 1, Questions D7, F12 and F13 
Fig.2 To what extent do you think the country should allow people from poorer countries in Europe to come and live? in

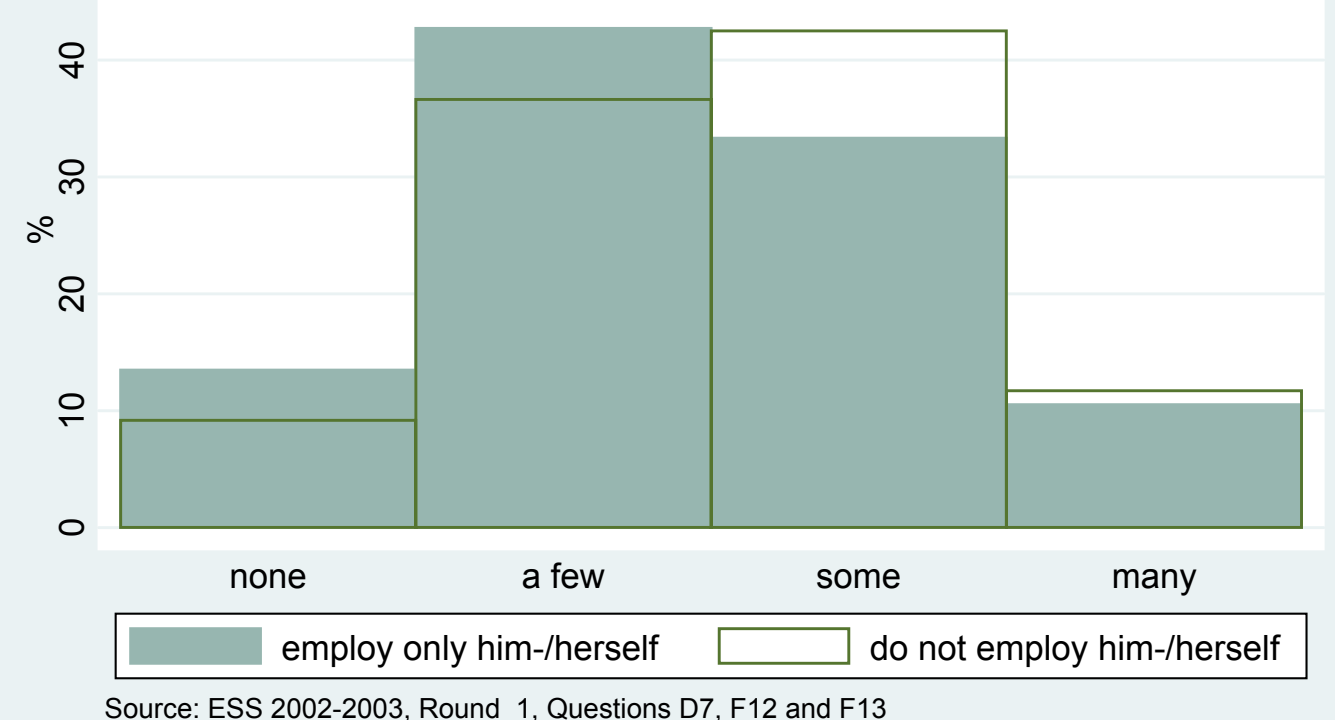




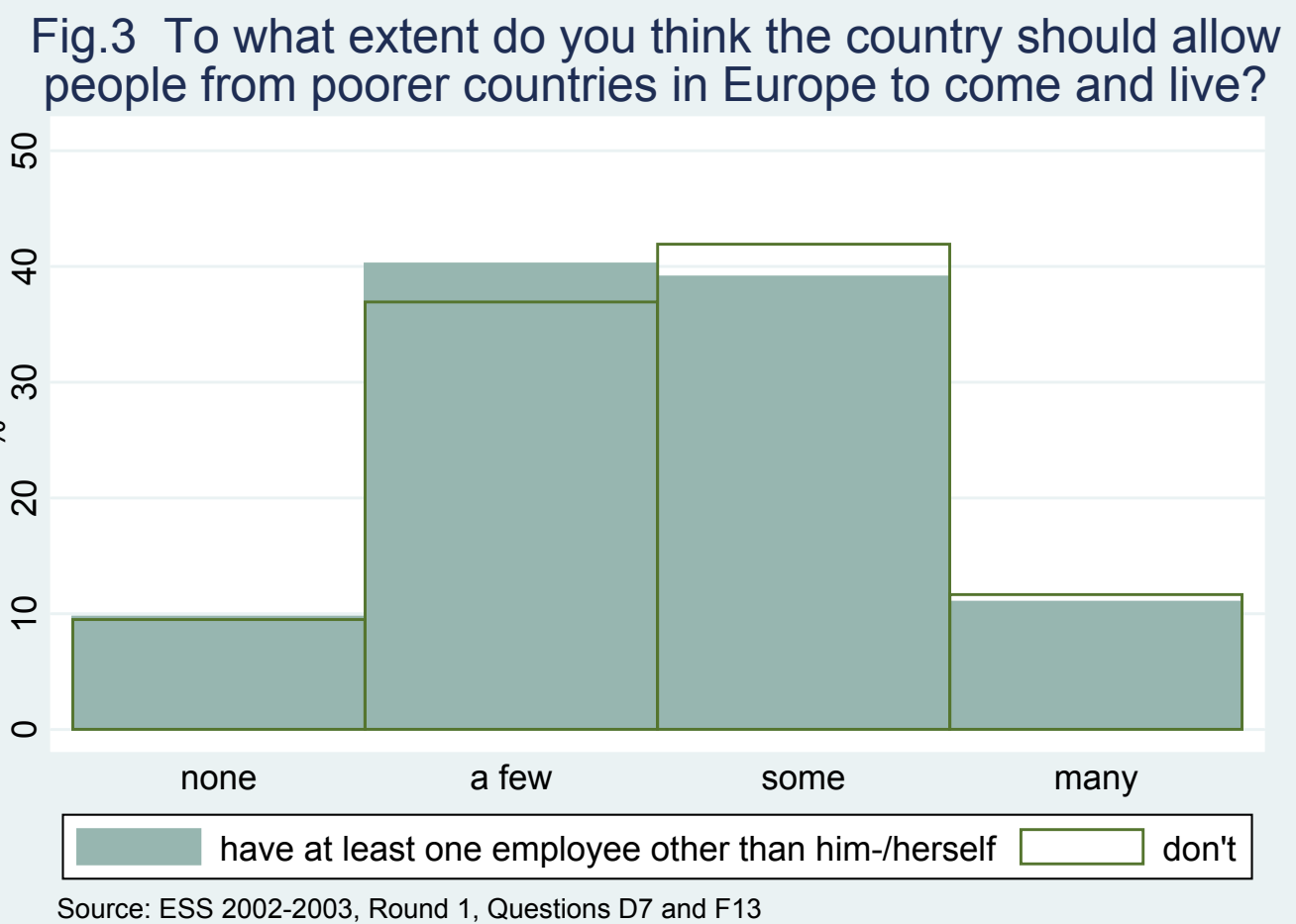


Table 1

Relative frequencies across attained educational levels

\begin{tabular}{|c|c|c|c|c|}
\hline Educational attainment & Overall & employ $=1$ & $\begin{array}{l}\text { employed only } \\
\text { him-/herself }\end{array}$ & $\begin{array}{l}\text { had at least } \\
\text { one employee } \\
\text { other than } \\
\text { him-/herself }\end{array}$ \\
\hline Not completed primary education & 4.66 & 6.90 & 9.69 & 2.61 \\
\hline Primary or first stage of basic & 15.54 & 21.65 & 24.69 & 16.98 \\
\hline Lower secondary or secondary stage of basic & 24.06 & 20.62 & 20.31 & 21.10 \\
\hline Upper secondary & 29.95 & 25.71 & 22.23 & 31.07 \\
\hline Post secondary, non-tertiary & 6.90 & 6.47 & 5.58 & 7.84 \\
\hline First stage of tertiary & 15.12 & 14.99 & 14.06 & 16.43 \\
\hline Second stage of tertiary & 3.77 & 3.65 & 3.44 & 3.99 \\
\hline Sample size & 28951 & 3695 & 2240 & 1455 \\
\hline
\end{tabular}

Source: ESS 2002-2003, Round 1, http://ess.nsd.uib.no, Questions F6, F12, F13

NB: The figures in each column may not add up to 100 due to rounding. 
Table 2

Extent of the sectoral employment of foreigners by country (isb)

\begin{tabular}{|c|c|c|c|c|c|c|c|c|c|c|c|c|c|c|c|c|c|}
\hline Country & $\begin{array}{c}\text { ector } \\
\text { a }\end{array}$ & $\begin{array}{c}\text { (NACE } \\
b\end{array}$ & $\begin{array}{ll}\cdot 1 & \mathrm{n} \\
\mathrm{C}\end{array}$ & $\begin{array}{ll}r \\
d\end{array}$ & $\begin{array}{l}\text { ion } \\
\text { e }\end{array}$ & $\begin{array}{l}\text { econ } \\
f\end{array}$ & $g$ & $\mathrm{~h}$ & $i$ & j & $\mathrm{k}$ & 1 & $\mathrm{~m}$ & $\mathrm{n}$ & $\circ$ & $\mathrm{p}$ & q \\
\hline Austria (AT) & 0.42 & $\ldots$ & 0.82 & 1.21 & 0.25 & 1.53 & 0.91 & 2.23 & 0.89 & 0.39 & 1.36 & 0.07 & 0.43 & 0.70 & 1.09 & 1.62 & 3.14 \\
\hline Germany (DE) & 0.45 & . & . & 1.35 & $\ldots$ & 1.07 & 0.90 & 3.32 & 1.00 & 0.40 & 1.10 & 0.23 & 0.47 & 0.67 & 0.97 & 1.30 & . \\
\hline Denmark (DK) & 1.00 & 0.49 & 0.65 & 1.12 & 0.23 & 0.46 & 0.86 & 3.27 & 0.97 & 0.34 & 1.66 & 0.27 & 0.98 & 0.74 & 0.91 & 1.00 & 12.86 \\
\hline Spain (ES) & 1.88 & 0.64 & 0.78 & 0.66 & 0.45 & 1.46 & 0.71 & 2.06 & 0.66 & 0.35 & 0.87 & 0.19 & 0.50 & 0.52 & 0.87 & 5.61 & . \\
\hline Finland (FI) & 0.35 & 0.42 & 0.19 & 0.93 & 0.19 & 0.72 & 0.97 & 2.90 & 0.82 & 0.36 & 1.62 & 0.33 & 1.57 & 0.57 & 1.08 & . & 11.58 \\
\hline France (FR) & 0.80 & . & 1.14 & 1.02 & 0.25 & 2.51 & 0.90 & 1.90 & 0.64 & 0.40 & 1.46 & 0.27 & 0.49 & 0.57 & 1.05 & 4.32 & 9.57 \\
\hline Greece (GR) & 1.21 & 1.12 & 0.59 & 1.03 & 0.16 & 2.86 & 0.53 & 1.35 & 0.41 & 0.14 & 0.64 & 0.11 & 0.24 & 0.30 & 0.56 & 7.94 & . . \\
\hline Ireland (IE) & 0.43 & 1.05 & 0.61 & 0.94 & 0.37 & 0.68 & 0.77 & 2.14 & 0.76 & 0.78 & 1.35 & 0.28 & 0.68 & 1.08 & 0.97 & 2.16 & .. \\
\hline Italy (IT) & 1.08 & 1.04 & 1.07 & 1.31 & 0.34 & 1.50 & 0.67 & 1.66 & 0.73 & 0.23 & 0.54 & 0.16 & 0.43 & 0.58 & 1.01 & . & . . \\
\hline Luxembourg (LU) & 0.44 & 0.00 & 1.23 & 0.88 & 0.13 & 1.72 & 0.98 & 1.74 & 0.62 & 1.10 & 1.37 & 0.12 & 0.34 & 0.72 & 0.90 & 1.94 & 1.99 \\
\hline Netherlands (NL) & 0.85 & 0.25 & 1.97 & 1.22 & 0.29 & 0.51 & 0.89 & 2.20 & 0.83 & 0.57 & 1.87 & 0.24 & 0.70 & 0.48 & 0.90 & . & .. \\
\hline Portugal (PT) & 0.44 & 0.43 & 0.89 & 0.60 & 0.65 & 2.65 & 0.68 & 1.80 & 0.58 & 0.31 & 1.38 & 0.29 & 0.49 & 0.81 & 1.46 & 1.84 & .. \\
\hline Sweden (SE) & 0.40 & 0.21 & 0.51 & 1.18 & 0.29 & 0.57 & 0.82 & 2.68 & 0.88 & 0.55 & 1.28 & 0.38 & 0.95 & 0.96 & 0.91 & 4.02 & . \\
\hline UK (UK) & 0.34 & 0.40 & 0.75 & 0.78 & 0.57 & 0.56 & 0.88 & 1.82 & 1.06 & 1.12 & 1.23 & 0.76 & 1.00 & 1.23 & 0.97 & 2.54 & . \\
\hline
\end{tabular}

Source: Eurostat Census 2001, http://europa.eu.int/comm/eurostat

Each figure is defined, for the corresponding country, as

((\# foreigners employed in the sector)/(\# all employed in the sector))/((\# foreigners employed in all sectors)/(\# all employed in all sectors)).

$a=$ agriculture, hunting, forestry

$\mathrm{b}=$ fishing

$\mathrm{c}=$ mining, quarrying

$\mathrm{d}=$ manufacturing

e = electricity, gas, water supply

$\mathrm{f}=$ construction

$g$ = wholesale/retail trade, repair of motor vehicles, motorcycles and personal/household goods

$\mathrm{h}=$ hotels, restaurants

$i=$ transport, storage, communication

$j$ = financial intermediation

$\mathrm{k}$ = real estate/renting/business activities

$l=$ public administration, defence, compulsory social security

$\mathrm{m}$ = education

$\mathrm{n}=$ health/social work

0 = other community/social/personal service activities

$\mathrm{p}=$ household activities

$q$ = extraterritorial organizations/bodies

Further details about the categories are in

Eurostat (1996) NACE Rev.1: Statistical Classification of Economic Activities in the European Community. 


\section{Table 3}

\section{Summary statistics}

\begin{tabular}{|c|c|c|c|c|c|c|c|c|}
\hline Variable & Definition & Mean & s.d. & Median & Min. & Max. & Obs. & ESS Q. No. \\
\hline anti & $\begin{array}{l}\text { Permissible number of immigrants from poorer European countries } \\
1=\text { "none" or "a few"; } 0=\text { "some" or "many" }\end{array}$ & 0.472 & 0.499 & 0.000 & 0.000 & 1.000 & 26013 & D7 \\
\hline employ $\dagger$ & $1=$ employ at least one person including oneself; $0=$ otherwise & 0.128 & 0.334 & 0.000 & 0.000 & 1.000 & 27211 & F12, F13 \\
\hline employself $\dagger$ & 1 = employ only oneself; 0 = otherwise & 0.077 & 0.268 & 0.000 & 0.000 & 1.000 & 27211 & $\mathrm{~F} 12, \mathrm{~F} 13$ \\
\hline employees † & Number of employees other than oneself & 0.624 & 20.341 & 0.000 & 0.000 & 3010.000 & 27211 & F13 \\
\hline employother $\dagger$ & $1=$ employ other than oneself; $0=$ otherwise & 0.050 & 0.219 & 0.000 & 0.000 & 1.000 & 27211 & F13 \\
\hline unemploy † & $1=$ unemployed and wanting $a j o b ; 0=$ otherwise & 0.049 & 0.216 & 0.000 & 0.000 & 1.000 & 27211 & F8a \\
\hline isb & Extent of the sectoral employment of foreigners & 0.991 & 0.664 & 0.907 & 0.000 & 7.940 & 23391 & F24 \\
\hline relinc & Intra-country relative net income per capita & 1.047 & 0.941 & 0.806 & 0.007 & 19.485 & 21138 & F1, F30 \\
\hline ed 0 & $1=$ less than primary education; $0=$ otherwise & 0.048 & 0.215 & 0.000 & 0.000 & 1.000 & 27082 & F6 \\
\hline ed 1 & $1=$ primary, basic or lower secondary; 0 = otherwise & 0.400 & 0.489 & 0.000 & 0.000 & 1.000 & 27082 & F6 \\
\hline ed 2 & $1=$ upper secondary or non-tertiary postsecondary; $0=$ otherwise & 0.368 & 0.482 & 0.000 & 0.000 & 1.000 & 27082 & F6 \\
\hline ed 3 & 1 = tertiary; 0 = otherwise & 0.182 & 0.386 & 0.000 & 0.000 & 1.000 & 27082 & F6 \\
\hline friend 0 & $1=$ no immigrant friend; 0 = otherwise & 0.520 & 0.499 & 1.000 & 0.000 & 1.000 & 27052 & D47 \\
\hline friend 1 & $1=a$ few immigrant friends; $0=$ otherwise & 0.325 & 0.468 & 0.000 & 0.000 & 1.000 & 27052 & D4 7 \\
\hline friend 2 & 1 = several immigrant friends; $0=$ otherwise & 0.153 & 0.360 & 0.000 & 0.000 & 1.000 & 27052 & D4 7 \\
\hline media & Hours spent on the media on current affairs per weekday & 1.597 & 1.281 & 1.250 & 0.000 & 9.750 & 27069 & $\mathrm{~A} 2, \mathrm{~A} 4, \mathrm{~A} 6$ \\
\hline racist & Discrimination against races different from the majority & 0.222 & 0.567 & 0.000 & -3.000 & 3.000 & 25723 & D4, D5 \\
\hline citizen & $1=$ citizen of the country; $0=$ non-citizen & 0.954 & 0.209 & 1.000 & 0.000 & 1.000 & 27192 & $\mathrm{C} 18$ \\
\hline ethnic & $1=$ belong to an ethnic minority in the country; $0=$ do not & 0.035 & 0.184 & 0.000 & 0.000 & 1.000 & 26726 & $\mathrm{C} 24$ \\
\hline fparent & $1=$ at least one parent was born abroad; $0=$ otherwise & 0.141 & 0.348 & 0.000 & 0.000 & 1.000 & 27173 & $\mathrm{C} 25, \mathrm{C} 27$ \\
\hline age & Approximate age in years at the time of interview & 47.130 & 18.276 & 46.000 & 14.000 & 110.000 & 27050 & F3, inwyr \\
\hline female $\dagger$ & $1=$ female $; 0=$ otherwise & 0.534 & 0.498 & 1.000 & 0.000 & 1.000 & 27211 & F2 \\
\hline
\end{tabular}

Sources: ESS 2002-2003, Round 1; Eurostat Census 2001

NB: Unweighted

† Code 0 includes missing observations. 
Table 4

\begin{tabular}{|c|c|c|c|c|c|c|c|c|c|c|c|c|c|c|c|}
\hline & EU & ${ }_{\text {RT }}$ & $\begin{array}{l}D E \\
\end{array}$ & $\begin{array}{ll}D K \\
\end{array}$ & ES & FI & $\begin{array}{ll}\text { FR } \\
\end{array}$ & GR & $\mathrm{IE}$ & IT & LU & $\begin{array}{ll}\mathrm{NL} \\
\mathrm{NL}\end{array}$ & PT & SE & UK \\
\hline employ & $\begin{array}{l}0.017 \\
0.019\end{array}$ & $\begin{array}{l}-0.197 * \star * \\
0.046\end{array}$ & $\begin{array}{r}-0.037 \\
0.042\end{array}$ & $\begin{array}{r}-0.009 \\
0.057\end{array}$ & $\begin{array}{l}0.027 \\
0.055\end{array}$ & $\begin{array}{l}0.018 \\
0.046\end{array}$ & $\begin{array}{l}0.012 \\
0.082\end{array}$ & $\begin{array}{l}0.005 \\
0.030\end{array}$ & $\begin{array}{l}0.044 \\
0.033\end{array}$ & $\begin{array}{l}0.057 \\
0.052\end{array}$ & $\begin{array}{r}-0.012 \\
0.080\end{array}$ & $\begin{array}{l}0.070 * \\
0.036\end{array}$ & $\begin{array}{l}0.016 \\
0.033\end{array}$ & $\begin{array}{l}0.065 * \star \\
0.036\end{array}$ & $\begin{array}{l}0.080 * \\
0.045\end{array}$ \\
\hline unemploy & $\begin{array}{l}0.081 * \star \star \star \\
0.023\end{array}$ & $\begin{array}{r}-0.010 \\
0.091\end{array}$ & $\begin{array}{l}0.108 * \star \\
0.043\end{array}$ & $\begin{array}{l}0.026 \\
0.083\end{array}$ & $\begin{array}{l}0.064 \\
0.044\end{array}$ & $\begin{array}{l}0.095 * * \\
0.041\end{array}$ & $\begin{array}{l}0.066 \\
0.061\end{array}$ & $\begin{array}{r}-0.001 \\
0.042\end{array}$ & $\begin{array}{l}0.011 \\
0.027\end{array}$ & $\begin{array}{l}0.135 * \\
0.085\end{array}$ & $\begin{array}{r}-0.133 \\
0.162\end{array}$ & $\begin{array}{r}-0.105 \\
0.091\end{array}$ & $\begin{array}{r}-0.092 \\
0.112\end{array}$ & $\begin{array}{l}0.021 \\
0.051\end{array}$ & $\begin{array}{l}0.022 \\
0.100\end{array}$ \\
\hline isb & $\begin{array}{l}0.000 \\
0.011\end{array}$ & $\begin{array}{l}0.066 \\
0.051\end{array}$ & $\begin{array}{l}0.038 \text { ** } \\
0.017\end{array}$ & $\begin{array}{r}-0.018 \\
0.045\end{array}$ & $\begin{array}{r}-0.008 \\
0.023\end{array}$ & $\begin{array}{c}-0.060 * \star \star \\
0.008\end{array}$ & $\begin{array}{l}0.016 \\
0.028\end{array}$ & $\begin{array}{l}0.014 * \star \\
0.006\end{array}$ & $\begin{array}{r}-0.025 \\
0.020\end{array}$ & $\begin{array}{r}-0.071 \\
0.075\end{array}$ & $\begin{array}{l}0.210 * \star \star \\
0.057\end{array}$ & $\begin{array}{l}0.024 \\
0.024\end{array}$ & $\begin{array}{r}-0.016 \\
0.039\end{array}$ & $\begin{array}{r}-0.014 \\
0.013\end{array}$ & $\begin{array}{c}-0.093 \star \\
0.044\end{array}$ \\
\hline relinc & $\begin{array}{r}-0.009 \\
0.006\end{array}$ & $\begin{array}{r}-0.012 \\
0.014\end{array}$ & $\begin{array}{r}-0.011 \\
0.014\end{array}$ & $\begin{array}{c}-0.002 \\
0.032\end{array}$ & $\begin{array}{r}-0.008 \\
0.029\end{array}$ & $\begin{array}{r}-0.006 \\
0.011\end{array}$ & $\begin{array}{r}-0.016 \\
0.019\end{array}$ & $\begin{array}{r}-0.006 \\
0.013\end{array}$ & $\begin{array}{r}-0.009 \\
0.020\end{array}$ & $\begin{array}{r}-0.029 \\
0.026\end{array}$ & $\begin{array}{l}0.013 \\
0.036\end{array}$ & $\begin{array}{r}-0.008 \\
0.018\end{array}$ & $\begin{array}{c}-0.017 * \\
0.010\end{array}$ & $\begin{array}{r}-0.002 \\
0.008\end{array}$ & $\begin{array}{r}-0.002 \\
0.011\end{array}$ \\
\hline edo & $\begin{array}{l}0.129 * \star \star \\
0.037\end{array}$ & $\begin{array}{l}0.171 \\
0.092\end{array}$ & + & $s(1)$ & $\begin{array}{l}0.106 \\
0.087\end{array}$ & $\begin{array}{l}0.039 \\
0.140\end{array}$ & $\begin{array}{l}0.094 \\
0.062\end{array}$ & $\begin{array}{l}0.001 \\
0.052\end{array}$ & $\begin{array}{l}0.219 * \star \star \\
0.084\end{array}$ & $\begin{array}{l}0.354 \text { *t } \\
0.161\end{array}$ & $\begin{array}{l}0.169 \\
0.183\end{array}$ & $\begin{array}{r}-0.037 \\
0.135\end{array}$ & $\begin{array}{l}0.152 \\
0.096\end{array}$ & $f(10)$ & $f(1)$ \\
\hline$e d I$ & $\begin{array}{l}0.098 * \star \star \star \\
0.015\end{array}$ & $\begin{array}{l}0.031 \\
0.035\end{array}$ & $\begin{array}{l}0.113 * \star \star \star \\
0.036\end{array}$ & $\begin{array}{l}0.136 * \star \star \star \\
0.036\end{array}$ & $\begin{array}{l}0.030 \\
0.057\end{array}$ & $\begin{array}{l}0.007 \\
0.017\end{array}$ & $\begin{array}{l}0.103 \text { k* } \\
0.044\end{array}$ & $\begin{array}{l}0.032 \\
0.020\end{array}$ & $\begin{array}{l}0.064 * \\
0.034\end{array}$ & $\begin{array}{l}0.175 * \star \star \\
0.053\end{array}$ & $\begin{array}{l}0.093 * \\
0.053\end{array}$ & $\begin{array}{l}0.063 \text { * } \\
0.033\end{array}$ & $\begin{array}{r}-0.018 \\
0.041\end{array}$ & $\begin{array}{l}0.059 * \star \star \\
0.019\end{array}$ & $\begin{array}{l}0.119 * \star \star \\
0.025\end{array}$ \\
\hline$e d 3$ & $\begin{array}{c}-0.124 * \star \star \\
0.015\end{array}$ & $\begin{array}{c}-0.084 \star \\
0.038\end{array}$ & $\begin{array}{c}-0.111 * * \star \\
0.019\end{array}$ & $\begin{array}{c}-0.163 * \star \star \\
0.036\end{array}$ & $\begin{array}{l}0.038 \\
0.075\end{array}$ & $\begin{array}{l}-0.114 \star \star 14 \star \\
0.034\end{array}$ & $\begin{array}{c}-0.113 * * * \\
0.026\end{array}$ & $\begin{array}{l}-0.147 * \star \star \\
0.032\end{array}$ & $\begin{array}{c}-0.107 * * * \\
0.032\end{array}$ & $\begin{array}{c}-0.027 \\
0.124\end{array}$ & $\begin{array}{r}-0.102 \\
0.066\end{array}$ & $\begin{array}{c}-0.169 * \star \star \\
0.027\end{array}$ & $\begin{array}{r}-0.050 \\
0.049\end{array}$ & $\begin{array}{c}-0.064 * \star \\
0.015\end{array}$ & $\begin{array}{l}-0.218 * * * \\
0.031\end{array}$ \\
\hline media & $\begin{array}{c}-0.017 * \star \star \\
0.006\end{array}$ & $\begin{array}{l}0.004 \\
0.011\end{array}$ & $\begin{array}{c}-0.025 * \\
0.013\end{array}$ & $\begin{array}{c}-0.024 * \\
0.013\end{array}$ & $\begin{array}{l}0.033 \\
0.023\end{array}$ & $\begin{array}{l}0.006 \\
0.006\end{array}$ & $\begin{array}{c}-0.031 * \star \\
0.016\end{array}$ & $\begin{array}{r}-0.017 \\
0.013\end{array}$ & $\begin{array}{r}-0.006 \\
0.014\end{array}$ & $\begin{array}{l}0.002 \\
0.029\end{array}$ & $\begin{array}{r}-0.004 \\
0.015\end{array}$ & $\begin{array}{l}0.007 \\
0.011\end{array}$ & $\begin{array}{r}-0.013 \\
0.032\end{array}$ & $\begin{array}{c}-0.002 \\
0.002\end{array}$ & $\begin{array}{l}-0.037 * \star \star \\
0.009\end{array}$ \\
\hline friendl & $\begin{array}{l}-0.119 * \star \star \\
0.011\end{array}$ & $\begin{array}{l}-0.144 * \star \star \\
0.035\end{array}$ & $\begin{array}{c}-0.130 * \star \star \\
0.018\end{array}$ & $\begin{array}{l}-0.110 * \star \star \\
0.023\end{array}$ & $\begin{array}{c}-0.179 \star \star \star \star \\
0.041\end{array}$ & $\begin{array}{l}-0.127 * \star \star \\
0.013\end{array}$ & $\begin{array}{l}-0.123 * \star \star \\
0.028\end{array}$ & $\begin{array}{l}-0.078 * \star \star \\
0.024\end{array}$ & $\begin{array}{r}-0.019 \\
0.028\end{array}$ & $\begin{array}{l}-0.157 * \star \star \\
0.050\end{array}$ & $\begin{array}{r}-0.006 \\
0.063\end{array}$ & $\begin{array}{l}-0.076 * \star \star \\
0.026\end{array}$ & $\begin{array}{l}-0.143 * \star \\
0.065\end{array}$ & $\begin{array}{c}-0.002 \\
0.024\end{array}$ & $\begin{array}{l}-0.076 * \star \star \\
0.027\end{array}$ \\
\hline friendz & $\begin{array}{l}-0.199 * \star \star \\
0.018\end{array}$ & $\begin{array}{c}-0.319 * \star \star \\
0.035\end{array}$ & $\begin{array}{c}-0.171 * * \star \\
0.037\end{array}$ & $\begin{array}{c}-0.270 * \star \star \\
0.058\end{array}$ & $\begin{array}{c}-0.314 * \star \star \\
0.051\end{array}$ & $\begin{array}{c}-0.299 * \star \star \star \\
0.041\end{array}$ & $\begin{array}{c}-0.228 * * * \\
0.038\end{array}$ & $\begin{array}{c}-0.152 * \star \star \star \\
0.052\end{array}$ & $\begin{array}{c}-0.130 * * * \\
0.021\end{array}$ & $\begin{array}{l}-0.256 * \star \\
0.057\end{array}$ & $\begin{array}{l}0.002 \\
0.064\end{array}$ & $\begin{array}{c}-0.086 \star * \star \\
0.036\end{array}$ & $\begin{array}{c}-0.317 * * \star \\
0.047\end{array}$ & $\begin{array}{c}-0.032 * \\
0.019\end{array}$ & $\begin{array}{l}-0.102 * * * \\
0.033\end{array}$ \\
\hline racist & $\begin{array}{l}0.129 * \star \star \\
0.012\end{array}$ & $\begin{array}{r}-0.002 \\
0.042\end{array}$ & $\begin{array}{l}0.122 * \star \star \star \\
0.022\end{array}$ & $\begin{array}{l}0.119 * \star \star \\
0.018\end{array}$ & $\begin{array}{l}0.021 \\
0.035\end{array}$ & $\begin{array}{l}0.029 * \star \\
0.013\end{array}$ & $\begin{array}{l}0.120 * \star \star \\
0.035\end{array}$ & $\begin{array}{l}0.017 \\
0.025\end{array}$ & $\begin{array}{l}0.101 * \star \star \\
0.029\end{array}$ & $\begin{array}{l}0.111 \text { * } \\
0.054\end{array}$ & $\begin{array}{r}-0.005 \\
0.038\end{array}$ & $\begin{array}{l}0.173 * \star \star \star \\
0.030\end{array}$ & $\begin{array}{l}0.116 * \star \star \star \\
0.029\end{array}$ & $\begin{array}{l}0.107 * \star \star \\
0.012\end{array}$ & $\begin{array}{l}0.209 * \star \star \\
0.032\end{array}$ \\
\hline citizen & $\begin{array}{l}0.073 \text { *t } \\
0.033\end{array}$ & $\begin{array}{r}-0.047 \\
0.115\end{array}$ & $\begin{array}{l}0.129 * \star \star \\
0.023\end{array}$ & $\begin{array}{r}-0.018 \\
0.124\end{array}$ & $\begin{array}{l}0.319 * \star \\
0.103\end{array}$ & $\begin{array}{l}0.140 * \\
0.081\end{array}$ & $\begin{array}{r}-0.090 \\
0.102\end{array}$ & $\begin{array}{l}0.215 * * \star \\
0.078\end{array}$ & $\begin{array}{l}0.149 * \star \star \\
0.039\end{array}$ & $f(1)$ & $\begin{array}{l}0.051 \\
0.069\end{array}$ & $\begin{array}{r}-0.033 \\
0.102\end{array}$ & $\begin{array}{l}0.074 \\
0.232\end{array}$ & $\begin{array}{r}-0.001 \\
0.034\end{array}$ & $\begin{array}{l}0.119 \\
0.128\end{array}$ \\
\hline ethric & $\begin{array}{l}0.018 \\
0.033\end{array}$ & $\begin{array}{l}0.095 * \\
0.049\end{array}$ & $\begin{array}{c}-0.087 \\
0.053\end{array}$ & $\begin{array}{l}0.080 \\
0.111\end{array}$ & $\begin{array}{c}-0.218 \text { ** } \\
0.082\end{array}$ & $\begin{array}{c}-0.261 * \star \\
0.111\end{array}$ & $\begin{array}{l}0.082 \\
0.090\end{array}$ & $\begin{array}{c}-0.087 * \star * \\
0.027\end{array}$ & $\begin{array}{r}-0.101 \\
0.058\end{array}$ & $\begin{array}{l}0.514 \text { * } \\
0.212\end{array}$ & $\begin{array}{c}-0.169 * \\
0.092\end{array}$ & $\begin{array}{l}0.060 \\
0.068\end{array}$ & $\begin{array}{l}0.014 \\
0.096\end{array}$ & $\begin{array}{l}0.016 \\
0.072\end{array}$ & $\begin{array}{l}0.063 \\
0.077\end{array}$ \\
\hline fparent & $\begin{array}{c}-0.051 * * \\
0.022\end{array}$ & $\begin{array}{l}0.007 \\
0.024\end{array}$ & $\begin{array}{l}0.017 \\
0.039\end{array}$ & $\begin{array}{l}0.015 \\
0.056\end{array}$ & $\begin{array}{l}0.009 \\
0.081\end{array}$ & $\begin{array}{l}0.077 \\
0.056\end{array}$ & $\begin{array}{l}-0.130 * \star \star \\
0.045\end{array}$ & $\begin{array}{l}-0.080 * * \\
0.035\end{array}$ & $\begin{array}{l}0.095 \\
0.075\end{array}$ & $\begin{array}{r}-0.095 \\
0.101\end{array}$ & $\begin{array}{r}-0.098 \\
0.060\end{array}$ & $\begin{array}{c}-0.080 * \\
0.045\end{array}$ & $\begin{array}{r}-0.103 \\
0.119\end{array}$ & $\begin{array}{l}0.031 \\
0.038\end{array}$ & $\begin{array}{r}-0.066 \\
0.045\end{array}$ \\
\hline female & $\begin{array}{r}-0.008 \\
0.013\end{array}$ & $\begin{array}{r}-0.003 \\
0.032\end{array}$ & $\begin{array}{c}-0.056 \text { ** } \\
0.023\end{array}$ & $\begin{array}{l}-0.064 * \\
0.034\end{array}$ & $\begin{array}{l}0.035 \\
0.036\end{array}$ & $\begin{array}{l}-0.094 * \star \star \\
0.026\end{array}$ & $\begin{array}{l}0.036 \\
0.042\end{array}$ & $\begin{array}{c}-0.050 * * \\
0.025\end{array}$ & $\begin{array}{c}-0.040 * \\
0.022\end{array}$ & $\begin{array}{l}0.029 \\
0.046\end{array}$ & $\begin{array}{l}0.020 \\
0.046\end{array}$ & $\begin{array}{r}-0.047 \\
0.030\end{array}$ & $\begin{array}{l}0.067 \\
0.045\end{array}$ & $\begin{array}{r}-0.020 \\
0.015\end{array}$ & $\begin{array}{l}0.017 \\
0.019\end{array}$ \\
\hline age & $\begin{array}{l}0.001 * * \star \\
0.000\end{array}$ & $\begin{array}{l}0.005 * * \star \\
0.001\end{array}$ & $\begin{array}{l}0.002 * * \\
0.000\end{array}$ & $\begin{array}{l}0.003 * * * \\
0.000\end{array}$ & $\begin{array}{l}0.000 \\
0.001\end{array}$ & $\begin{array}{l}0.007 * * * \\
0.000\end{array}$ & $\begin{array}{l}0.003 * * * \\
0.000\end{array}$ & $\begin{array}{l}0.001 \text { ** } \\
0.000\end{array}$ & $\begin{array}{l}0.000 \\
0.000\end{array}$ & $\begin{array}{l}0.000 \\
0.001\end{array}$ & $\begin{array}{l}0.000 \\
0.001\end{array}$ & $\begin{array}{l}0.000 \\
0.000\end{array}$ & $\begin{array}{l}0.002 \\
0.002\end{array}$ & $\begin{array}{l}0.000 \\
0.000\end{array}$ & $\begin{array}{l}0.000 \\
0.000\end{array}$ \\
\hline $\begin{array}{l}\text { log pseudolikel ihood } \\
\text { McFadden's (1974) LRI } \\
R^{2} \text { p } \\
\text { Sum of PCP }\end{array}$ & $\begin{array}{r}-10621.331 \\
0.1110 \\
0.280 \\
1.341\end{array}$ & $\begin{array}{r}-678.319 \\
0.103 \\
0.190 \\
1.284\end{array}$ & $\begin{array}{r}-1189.042 \\
0.078 \\
0.088 \\
1.171\end{array}$ & $\begin{array}{r}-751.780 \\
0.083 \\
0.194 \\
1.260\end{array}$ & $\begin{array}{r}-477.409 \\
0.061 \\
0.225 \\
1.255\end{array}$ & $\begin{array}{r}-1012.549 \\
0.116 \\
0.274 \\
1.327\end{array}$ & $\begin{array}{r}-661.650 \\
0.118 \\
0.200 \\
1.294\end{array}$ & $\begin{array}{r}-537.589 \\
0.127 \\
0.054 \\
1.150\end{array}$ & $\begin{array}{r}-819.938 \\
0.052 \\
0.025 \\
1.063\end{array}$ & $\begin{array}{r}-272.724 \\
0.091 \\
0.090 \\
1.167\end{array}$ & $\begin{array}{r}-408.045 \\
0.050 \\
0.149 \\
1.155\end{array}$ & $\begin{array}{r}-1154.942 \\
0.054 \\
0.068 \\
1.136\end{array}$ & $\begin{array}{r}-509.107 \\
0.089 \\
0.077 \\
1.166\end{array}$ & $\begin{array}{r}-595.321 \\
0.087 \\
0.009 \\
1.028\end{array}$ & $\begin{array}{r}-995.562 \\
0.132 \\
0.271 \\
1.315\end{array}$ \\
\hline & 17640.000 & 1123.000 & 1979.000 & 1197.000 & 734.000 & 1663.000 & 1112.000 & 1280.000 & 1419.000 & 480.000 & 620.000 & 1820.000 & 837.000 & 1697.000 & 1666.000 \\
\hline
\end{tabular}

Al1 non-missing observations are 0 , and the corresponding variable is dropped in estimation.
$\mathrm{s}(\mathrm{n}) \mathrm{n}$ observations predict success perfectly, and the corresponding variable and the $\mathrm{n}$ observations are dropped in estimation.
$\mathrm{f}(\mathrm{n}) \mathrm{n}$. observations predict failure perfectly, and the corresponding variable and the $\mathrm{n}$ observations are dropped in estimation.

The three goodness-of-fit measures are described in verbeek (2004: 194-197). Sum of PCP is the sum of the proportions of correct predictions for anti $=1$ and anti $=0$.

Sampling weights provided by ESS are applied in maximum likelihood estimation.
Eor EU, a further weight adjustment is made to reflect the population size of each country.

Estimated standard errors are based on the assumption that observations are not necessarily independent within each region of a country, but are independent across regions of the country.

Eor EU, 13 country dunnies are included with uK being the reference. 
Table 5

Probit estimates of marginal effects evaluated at the means of explanatory variables

\begin{tabular}{|c|c|c|c|c|c|c|c|c|c|c|c|c|c|c|c|}
\hline & $\mathrm{EU}$ & $\mathrm{AT}_{\mathrm{AT}}$ & $\mathrm{DE}$ & $D K$ & ES & ET & FR & GR & IE & IT & $\mathrm{LU}$ & NL & PT & $S E$ & UK \\
\hline employ & $\begin{array}{c}-0.020 \\
0.033\end{array}$ & $\begin{array}{c}-0.302 \text { ** } \\
0.119\end{array}$ & $\begin{array}{l}0.006 \\
0.061\end{array}$ & $\begin{array}{l}0.113 \\
0.115\end{array}$ & $\begin{array}{l}-0.153 * * \\
0.063\end{array}$ & $\begin{array}{l}0.115 * \star \\
0.055\end{array}$ & $\begin{array}{l}0.012 \\
0.094\end{array}$ & $\begin{array}{r}-0.013 \\
0.032\end{array}$ & $\begin{array}{l}0.013 \\
0.077\end{array}$ & $\begin{array}{l}0.001 \\
0.139\end{array}$ & $\begin{array}{l}0.321 * \star \\
0.126\end{array}$ & $\begin{array}{l}0.163 \\
0.100\end{array}$ & $\begin{array}{l}0.037 \\
0.055\end{array}$ & $\begin{array}{l}0.131 * \\
0.089\end{array}$ & $\begin{array}{r}-0.112 \\
0.110\end{array}$ \\
\hline employ $\mathrm{x}$ isb & $\begin{array}{l}0.035 \\
0.030\end{array}$ & $\begin{array}{l}0.105 \\
0.099\end{array}$ & $\begin{array}{r}-0.045 \\
0.048\end{array}$ & $\begin{array}{r}-0.118 \\
0.102\end{array}$ & $\begin{array}{l}0.133 * * \\
0.051\end{array}$ & $\begin{array}{r}-0.116 \\
0.078\end{array}$ & $\begin{array}{l}0.000 \\
0.035\end{array}$ & $\begin{array}{l}0.018 \\
0.026\end{array}$ & $\begin{array}{l}0.034 \\
0.083\end{array}$ & $\begin{array}{l}0.064 \\
0.166\end{array}$ & $\begin{array}{c}-0.350 * \star \\
0.157\end{array}$ & $\begin{array}{r}-0.083 \\
0.081\end{array}$ & $\begin{array}{c}-0.021 \\
0.028\end{array}$ & $\begin{array}{r}-0.048 \\
0.040\end{array}$ & $\begin{array}{l}0.194 \text { * } \\
0.111\end{array}$ \\
\hline unemploy & $\begin{array}{l}0.137 * \star \star \\
0.047\end{array}$ & $\begin{array}{r}-0.210 \\
0.265\end{array}$ & $\begin{array}{l}0.294 * \star * \\
0.061\end{array}$ & $\begin{array}{r}-0.044 \\
0.151\end{array}$ & $\begin{array}{l}0.200 * \star \\
0.084\end{array}$ & $\begin{array}{l}0.033 \\
0.105\end{array}$ & $\begin{array}{l}0.100 \\
0.124\end{array}$ & $\begin{array}{r}-0.108 \\
0.119\end{array}$ & $\begin{array}{r}-0.024 \\
0.187\end{array}$ & $\begin{array}{c}-0.239 * \\
0.089\end{array}$ & $\begin{array}{c}-0.513 * \star \\
0.026\end{array}$ & $\begin{array}{r}-0.146 \\
0.140\end{array}$ & $\begin{array}{r}-0.015 \\
0.311\end{array}$ & $\begin{array}{r}-0.048 \\
0.073\end{array}$ & $\begin{array}{l}0.381 \\
0.206\end{array}$ \\
\hline unemploy $\times$ isb & $\begin{array}{c}-0.047 \\
0.031\end{array}$ & $\begin{array}{l}0.182 \\
0.246\end{array}$ & $\begin{array}{c}-0.141 * * * \\
0.041\end{array}$ & $\begin{array}{l}0.068 \\
0.115\end{array}$ & $\begin{array}{l}-0.121 * * \\
0.052\end{array}$ & $\begin{array}{l}0.062 \\
0.078\end{array}$ & $\begin{array}{r}-0.029 \\
0.063\end{array}$ & $\begin{array}{l}0.078 \\
0.062\end{array}$ & $\begin{array}{l}0.034 \\
0.179\end{array}$ & $\begin{array}{l}0.444 * \star \star \\
0.130 \\
0\end{array}$ & $\begin{array}{l}1.349 \text { * } \\
0.697\end{array}$ & $\begin{array}{l}0.039 \\
0.146\end{array}$ & $\begin{array}{r}-0.075 \\
0.205\end{array}$ & $\begin{array}{l}0.074 \\
0.084\end{array}$ & $\begin{array}{c}-0.426 * \\
0.251\end{array}$ \\
\hline$i s b$ & $\begin{array}{l}0.000 \\
0.012\end{array}$ & $\begin{array}{l}0.048 \\
0.056\end{array}$ & $\begin{array}{l}0.066 * \star \star \star \\
0.016\end{array}$ & $\begin{array}{r}-0.010 \\
0.050\end{array}$ & $\begin{array}{r}-0.016 \\
0.025\end{array}$ & $\begin{array}{l}-0.052 \star \star \star \star \\
0.009\end{array}$ & $\begin{array}{l}0.018 \\
0.025\end{array}$ & $\begin{array}{l}0.005 \\
0.006\end{array}$ & $\begin{array}{r}-0.034 \\
0.026\end{array}$ & $\begin{array}{r}-0.111 \\
0.095\end{array}$ & $\begin{array}{l}0.231 * \star \star \\
0.061\end{array}$ & $\begin{array}{l}0.030 \\
0.025\end{array}$ & $\begin{array}{r}-0.010 \\
0.042\end{array}$ & $\begin{array}{c}-0.012 \\
0.013\end{array}$ & $\begin{array}{c}-0.106 \text { ** } \\
0.043\end{array}$ \\
\hline relinc & $\begin{array}{r}-0.009 \\
0.006\end{array}$ & $\begin{array}{r}-0.013 \\
0.014\end{array}$ & $\begin{array}{r}-0.010 \\
0.014\end{array}$ & $\begin{array}{l}0.000 \\
0.032\end{array}$ & $\begin{array}{r}-0.005 \\
0.029\end{array}$ & $\begin{array}{r}-0.005 \\
0.011\end{array}$ & $\begin{array}{r}-0.016 \\
0.019\end{array}$ & $\begin{array}{r}-0.006 \\
0.013\end{array}$ & $\begin{array}{r}-0.010 \\
0.020\end{array}$ & $\begin{array}{r}-0.029 \\
0.026\end{array}$ & $\begin{array}{l}0.012 \\
0.036\end{array}$ & $\begin{array}{r}-0.008 \\
0.018\end{array}$ & $\begin{array}{c}-0.016 \\
0.010\end{array}$ & $\begin{array}{r}-0.002 \\
0.008\end{array}$ & $\begin{array}{r}-0.002 \\
0.012\end{array}$ \\
\hline edo & $\begin{array}{l}0.128 * \star \star \star \\
0.037\end{array}$ & $\begin{array}{l}0.181 * \\
0.090\end{array}$ & + & $s(1)$ & $\begin{array}{l}0.100 \\
0.084\end{array}$ & $\begin{array}{l}0.040 \\
0.139\end{array}$ & $\begin{array}{l}0.094 \\
0.062\end{array}$ & $\begin{array}{l}0.005 \\
0.049\end{array}$ & $\begin{array}{l}0.220 * \star * * \\
0.086\end{array}$ & $\begin{array}{l}0.372 * \star \\
0.161\end{array}$ & $\begin{array}{l}0.174 \\
0.180\end{array}$ & $\begin{array}{r}-0.036 \\
0.136\end{array}$ & $\begin{array}{l}0.152 \\
0.097\end{array}$ & $\mathrm{f}(10)$ & $f(1)$ \\
\hline edr & $\begin{array}{l}0.098 * \star \star \star \\
0.015\end{array}$ & $\begin{array}{l}0.033 \\
0.036\end{array}$ & $\begin{array}{l}0.114 * \star \star \star \\
0.037\end{array}$ & $\begin{array}{l}0.136 * \star \star \\
0.036\end{array}$ & $\begin{array}{l}0.028 \\
0.053\end{array}$ & $\begin{array}{l}0.005 \\
0.018\end{array}$ & $\begin{array}{l}0.104 * \star \\
0.044\end{array}$ & $\begin{array}{l}0.035 \text { * } \\
0.020\end{array}$ & $\begin{array}{l}0.066 * \star \\
0.032\end{array}$ & $\begin{array}{l}0.171 * \star \star \\
0.054\end{array}$ & $\begin{array}{l}0.100 \text { * } \\
0.053\end{array}$ & $\begin{array}{l}0.061 * \\
0.033\end{array}$ & $\begin{array}{c}-0.017 \\
0.038\end{array}$ & $\begin{array}{l}0.060 * \star \star \star \\
0.020\end{array}$ & $\begin{array}{l}0.117 * \star \star \\
0.025\end{array}$ \\
\hline ed3 & $\begin{array}{c}-0.124 * \star \star \\
0.015\end{array}$ & $\begin{array}{c}-0.085 * \star \\
0.038\end{array}$ & $\begin{array}{l}-0.111 \text { * } \\
0.019\end{array}$ & $\begin{array}{l}-0.165 * \star \star \\
0.037\end{array}$ & $\begin{array}{l}0.036 \\
0.076\end{array}$ & $\begin{array}{l}-0.113 * \star \star \\
0.034 \\
0\end{array}$ & $\begin{array}{l}-0.113 * \star \star \\
0.025\end{array}$ & $\begin{array}{l}-0.146 * \star \star \\
0.034\end{array}$ & $\begin{array}{l}-0.107 * \star \star \\
0.032\end{array}$ & $\begin{array}{r}-0.039 \\
0.119\end{array}$ & $\begin{array}{r}-0.088 \\
0.066\end{array}$ & $\begin{array}{c}-0.170 * \star \star \\
0.027\end{array}$ & $\begin{array}{r}-0.051 \\
0.047\end{array}$ & $\begin{array}{l}-0.063 * \star \star * \\
0.015\end{array}$ & $\begin{array}{c}-0.221 * \star \star \\
0.031\end{array}$ \\
\hline media & $\begin{array}{l}-0.017 * \star \star \star \\
0.006\end{array}$ & $\begin{array}{l}0.003 \\
0.011\end{array}$ & $\begin{array}{c}-0.026 * \\
0.014\end{array}$ & $\begin{array}{c}-0.025 * \\
0.013\end{array}$ & $\begin{array}{l}0.030 \\
0.022\end{array}$ & $\begin{array}{l}0.006 \\
0.007\end{array}$ & $\begin{array}{c}-0.032 \text { ** } \\
0.016\end{array}$ & $\begin{array}{r}-0.018 \\
0.013\end{array}$ & $\begin{array}{r}-0.006 \\
0.014\end{array}$ & $\begin{array}{l}0.001 \\
0.029\end{array}$ & $\begin{array}{r}-0.007 \\
0.015\end{array}$ & $\begin{array}{l}0.007 \\
0.011\end{array}$ & $\begin{array}{r}-0.013 \\
0.033\end{array}$ & $\begin{array}{r}-0.002 \\
0.002\end{array}$ & $\begin{array}{l}-0.038 * \star \star \\
0.009\end{array}$ \\
\hline friendl & $\begin{array}{c}-0.119 * \star \star \\
0.011\end{array}$ & $\begin{array}{l}-0.146 * \star \star \\
0.034\end{array}$ & $\begin{array}{l}-0.130 * \star \star \\
0.018\end{array}$ & $\begin{array}{l}-0.110 * \star \star \\
0.023\end{array}$ & $\begin{array}{l}-0.182 \star \star \star \star \star \\
0.041\end{array}$ & $\begin{array}{l}-0.125 * \star \star \\
0.014\end{array}$ & $\begin{array}{c}-0.123 * \star \star \star \\
0.028\end{array}$ & $\begin{array}{l}-0.080 * \star \star \\
0.024\end{array}$ & $\begin{array}{c}-0.019 \\
0.028\end{array}$ & $\begin{array}{l}-0.154 * * \star \\
0.047\end{array}$ & $\begin{array}{l}0.000 \\
0.063\end{array}$ & $\begin{array}{l}-0.077 * \star \star * \\
0.026\end{array}$ & $\begin{array}{l}-0.142 * \star \\
0.066\end{array}$ & $\begin{array}{l}-0.002 \\
0.024\end{array}$ & $\begin{array}{l}-0.078 * * * \\
0.027\end{array}$ \\
\hline friend 2 & $\begin{array}{l}-0.199 * \star \star \star \\
0.018\end{array}$ & $\begin{array}{l}-0.324 * \star \star \star \\
0.037\end{array}$ & $\begin{array}{l}-0.173 * \star \star \\
0.037 \\
\end{array}$ & $\begin{array}{l}-0.272 * \star \star \star \\
0.058\end{array}$ & $\begin{array}{l}-0.315 * \star \star \\
0.050 \\
0\end{array}$ & $\begin{array}{l}-0.301 * \star \star \\
0.041\end{array}$ & $\begin{array}{l}-0.227 * \star \star \star \\
0.038\end{array}$ & $\begin{array}{l}-0.148 * \star \star \\
0.049 \\
\end{array}$ & $\begin{array}{l}-0.130 * \star \star \\
0.020\end{array}$ & $\begin{array}{l}-0.256 * \star \\
0.055\end{array}$ & $\begin{array}{l}0.005 \\
0.064\end{array}$ & $\begin{array}{l}-0.085 * * \\
0.036\end{array}$ & $\begin{array}{l}-0.320 \star \star \star \star \\
0.041\end{array}$ & $\begin{array}{c}-0.030 * \\
0.018\end{array}$ & $\begin{array}{l}-0.107 * \star \star \star \\
0.033\end{array}$ \\
\hline racist & $\begin{array}{l}0.129 * * * \\
0.012\end{array}$ & $\begin{array}{l}0.000 \\
0.042\end{array}$ & $\begin{array}{l}0.124 * * \star \\
0.023\end{array}$ & $\begin{array}{l}0.120 * * * \\
0.018\end{array}$ & $\begin{array}{l}0.024 \\
0.036\end{array}$ & $\begin{array}{l}0.027 * * \\
0.013\end{array}$ & $\begin{array}{l}0.120 * * \star \\
0.035\end{array}$ & $\begin{array}{l}0.018 \\
0.025\end{array}$ & $\begin{array}{l}0.102 * * \star \\
0.029\end{array}$ & $\begin{array}{l}0.114 * * \\
0.054\end{array}$ & $\begin{array}{r}-0.001 \\
0.038\end{array}$ & $\begin{array}{l}0.173 * * * \\
0.030\end{array}$ & $\begin{array}{l}0.115 * * * \\
0.028\end{array}$ & $\begin{array}{l}0.107 * * \star \\
0.013\end{array}$ & $\begin{array}{l}0.212 * * * \\
0.034\end{array}$ \\
\hline citizen & $\begin{array}{l}0.071 \text { * } \\
0.033\end{array}$ & $\begin{array}{r}-0.045 \\
0.115\end{array}$ & $\begin{array}{l}0.127 * \star * \star \\
0.025\end{array}$ & $\begin{array}{c}-0.012 \\
0.124\end{array}$ & $\begin{array}{l}0.317 \text { ** } \\
0.106\end{array}$ & $\begin{array}{l}0.135 * \\
0.077\end{array}$ & $\begin{array}{r}-0.090 \\
0.102\end{array}$ & $\begin{array}{l}0.220 * \star \star \star \\
0.080\end{array}$ & $\begin{array}{l}0.149 * * \star \\
0.039 \\
0.04\end{array}$ & $f(1)$ & $\begin{array}{l}0.070 \\
0.070\end{array}$ & $\begin{array}{r}-0.031 \\
0.102\end{array}$ & $\begin{array}{l}0.071 \\
0.234\end{array}$ & $\begin{array}{l}0.000 \\
0.035\end{array}$ & $\begin{array}{l}0.118 \\
0.124\end{array}$ \\
\hline ethnic & $\begin{array}{l}0.018 \\
0.033\end{array}$ & $\begin{array}{l}0.099 * \\
0.052\end{array}$ & $\begin{array}{r}-0.092 \\
0.053\end{array}$ & $\begin{array}{l}0.086 \\
0.113\end{array}$ & $\begin{array}{c}-0.189 \star \star \\
0.082\end{array}$ & $\begin{array}{c}-0.263 * * \\
0.111\end{array}$ & $\begin{array}{l}0.081 \\
0.090\end{array}$ & $\begin{array}{l}-0.085 * \star \star \\
0.026\end{array}$ & $\begin{array}{c}-0.104 * \\
0.056\end{array}$ & $\begin{array}{l}0.513 * \\
0.208\end{array}$ & $\begin{array}{c}-0.168 \text { * } \\
0.093\end{array}$ & $\begin{array}{l}0.061 \\
0.068\end{array}$ & $\begin{array}{l}0.010 \\
0.092\end{array}$ & $\begin{array}{l}0.020 \\
0.071\end{array}$ & $\begin{array}{l}0.058 \\
0.079\end{array}$ \\
\hline fparent & $\begin{array}{c}-0.051 * * \\
0.022\end{array}$ & $\begin{array}{l}0.008 \\
0.026\end{array}$ & $\begin{array}{l}0.016 \\
0.038\end{array}$ & $\begin{array}{l}0.014 \\
0.057\end{array}$ & $\begin{array}{l}0.016 \\
0.083\end{array}$ & $\begin{array}{l}0.077 \\
0.057\end{array}$ & $\begin{array}{l}-0.130 * * * \\
0.046\end{array}$ & $\begin{array}{c}-0.080 * * \\
0.036\end{array}$ & $\begin{array}{l}0.096 \\
0.075\end{array}$ & $\begin{array}{r}-0.101 \\
0.100\end{array}$ & $\begin{array}{r}-0.090 \\
0.061\end{array}$ & $\begin{array}{c}-0.079 * \\
0.045\end{array}$ & $\begin{array}{r}-0.106 \\
0.121\end{array}$ & $\begin{array}{l}0.028 \\
0.036\end{array}$ & $\begin{array}{r}-0.063 \\
0.048\end{array}$ \\
\hline female & $\begin{array}{c}-0.009 \\
0.013\end{array}$ & $\begin{array}{r}-0.002 \\
0.030\end{array}$ & $\begin{array}{c}-0.051 \text { ** } \\
0.023\end{array}$ & $\begin{array}{c}-0.063 * \\
0.034\end{array}$ & $\begin{array}{l}0.031 \\
0.036\end{array}$ & $\begin{array}{l}-0.092 \star \star \star \star \\
0.027\end{array}$ & $\begin{array}{l}0.036 \\
0.042\end{array}$ & $\begin{array}{c}-0.049 * \star \\
0.024\end{array}$ & $\begin{array}{c}-0.040 * \\
0.022\end{array}$ & $\begin{array}{l}0.031 \\
0.046\end{array}$ & $\begin{array}{l}0.021 \\
0.046\end{array}$ & $\begin{array}{c}-0.047 \\
0.030\end{array}$ & $\begin{array}{l}0.066 \\
0.043\end{array}$ & $\begin{array}{r}-0.020 \\
0.015\end{array}$ & $\begin{array}{l}0.015 \\
0.018\end{array}$ \\
\hline age & $\begin{array}{l}0.001 * \star \star \\
0.000\end{array}$ & $\begin{array}{l}0.005 * \star \star \star \\
0.001\end{array}$ & $\begin{array}{l}0.002 \text { *夫 } \\
0.000\end{array}$ & $\begin{array}{l}0.003 * \star \star \star \\
0.000\end{array}$ & $\begin{array}{l}0.000 \\
0.001\end{array}$ & $\begin{array}{l}0.007 * * \star \\
0.000\end{array}$ & $\begin{array}{l}0.003 * \star \star \star \\
0.000\end{array}$ & $\begin{array}{l}0.001 * * \\
0.000\end{array}$ & $\begin{array}{l}0.000 \\
0.000\end{array}$ & $\begin{array}{l}0.000 \\
0.001\end{array}$ & $\begin{array}{l}0.000 \\
0.001\end{array}$ & $\begin{array}{l}0.000 \\
0.000\end{array}$ & $\begin{array}{l}0.002 \\
0.002\end{array}$ & $\begin{array}{l}0.000 \\
0.000\end{array}$ & $\begin{array}{l}0.000 \\
0.000\end{array}$ \\
\hline $\begin{array}{l}\text { log pseudolikelihood } \\
\text { McFadden's (1974) LRI } \\
\text { R }^{2} \mathrm{p} \text {. } \\
\text { Sum of PCP }\end{array}$ & $\begin{array}{r}-10616.928 \\
0.110 \\
0.279 \\
1.341\end{array}$ & $\begin{array}{r}-677.381 \\
0.104 \\
0.211 \\
1.304\end{array}$ & $\begin{array}{r}-1185.497 \\
0.081 \\
0.092 \\
1.177\end{array}$ & $\begin{array}{r}-751.032 \\
0.0884 \\
0.198 \\
1.264\end{array}$ & $\begin{array}{r}-473.164 \\
0.069 \\
0.228 \\
1.257\end{array}$ & $\begin{array}{r}-1011.149 \\
0.117 \\
0.280 \\
1.334\end{array}$ & $\begin{array}{r}-661.593 \\
0.118 \\
0.202 \\
1.295\end{array}$ & $\begin{array}{r}-535.131 \\
0.131 \\
0.062 \\
1.158\end{array}$ & $\begin{array}{r}-819.780 \\
0.052 \\
0.023 \\
1.061\end{array}$ & $\begin{array}{r}-270.533 \\
0.098 \\
0.096 \\
1.171\end{array}$ & $\begin{array}{r}-404.639 \\
0.058 \\
0.175 \\
1.180\end{array}$ & $\begin{array}{r}-1154.325 \\
0.055 \\
0.068 \\
1.136\end{array}$ & $\begin{array}{r}-508.906 \\
0.0089 \\
0.083 \\
1.170\end{array}$ & $\begin{array}{r}-594.505 \\
0.0099 \\
0.009 \\
1.032\end{array}$ & $\begin{array}{r}-991.701 \\
0.136 \\
0.272 \\
1.316\end{array}$ \\
\hline abs. & 17640.000 & 1123.000 & 1979.000 & 1197.000 & 734.000 & 1663.000 & 1112.000 & 1280.000 & 1419.000 & 480.000 & 620.000 & 1820.000 & 837.000 & 1697.000 & 1666.000 \\
\hline
\end{tabular}

I Al1 non-missing observations are 0 , and the corresponding variable is dropped in estimation.

$\mathrm{f}(\mathrm{n}) \mathrm{n}$ observations predict failure perfectly, and the corresponding variable and the $\mathrm{n}$ observations are dropped in estimation.

The three goodness-of-fit measures are described in verbeek (2004: 194-197). Sum of PCP is the sum of the proportions of correct predictions for anti $=1$ and anti $=0$.

Sampling weights provided by ESS are applied in maximum likeli hood estimation.
For EU, a further weight adjustment is made to reflect the population oise of

Estimated standard errors are based on the assumption that observations are not necessarily independent within each region of a country, but are independent across regions of the country.

For EU, 13 country durnies are included with UK being the reference. 
Table 6

(a) Probit estimates of marginal effects evaluated at the means of explanatory variables: those who thought that immigration would depress wages on average

\begin{tabular}{|c|c|c|c|c|c|c|c|c|c|c|c|c|c|c|c|}
\hline & EU & ${ }^{A T}$ & DE & $D K$ & ES & FI & FR & GR & $\mathrm{IE}$ & IT & IU & NL & PT & SE & UK \\
\hline employ & $\begin{array}{r}-0.002 \\
0.038\end{array}$ & $\begin{array}{c}-0.172 \text { ** } \\
0.073\end{array}$ & $\begin{array}{r}-0.069 \\
0.084\end{array}$ & $\begin{array}{l}0.000 \\
0.149\end{array}$ & $\begin{array}{r}-0.108 \\
0.121\end{array}$ & $\begin{array}{l}0.002 \\
0.067\end{array}$ & $\begin{array}{l}0.086 \\
0.144\end{array}$ & $\begin{array}{l}0.002 \\
0.020\end{array}$ & $\begin{array}{l}0.021 \\
0.072\end{array}$ & $\begin{array}{l}0.058 \\
0.121\end{array}$ & $\begin{array}{r}-0.074 \\
0.149\end{array}$ & $\begin{array}{l}0.083 \\
0.093\end{array}$ & $\begin{array}{l}0.027 \\
0.042\end{array}$ & $\begin{array}{l}0.013 \\
0.138\end{array}$ & $\begin{array}{r}-0.002 \\
0.058\end{array}$ \\
\hline unemploy & $\begin{array}{l}0.090 * \star \star \\
0.030\end{array}$ & $\begin{array}{l}0.018 \\
0.125\end{array}$ & $\begin{array}{l}0.102 \\
0.064\end{array}$ & $\begin{array}{l}0.151 \\
0.166\end{array}$ & $\begin{array}{l}0.137 \\
0.092\end{array}$ & $\begin{array}{l}0.044 \\
0.038\end{array}$ & $\begin{array}{l}0.102 \\
0.084\end{array}$ & $\begin{array}{r}-0.014 \\
0.063\end{array}$ & $\begin{array}{l}0.002 \\
0.082\end{array}$ & $\begin{array}{l}0.147 * \\
0.081\end{array}$ & $\begin{array}{l}0.026 \\
0.249\end{array}$ & $\begin{array}{l}.138 \\
0.188\end{array}$ & $\begin{array}{r}-0.117 \\
0.094\end{array}$ & $\begin{array}{r}-0.092 \\
0.084\end{array}$ & $\begin{array}{r}-0.030 \\
0.069\end{array}$ \\
\hline$i s b$ & $\begin{array}{l}0.004 \\
0.013\end{array}$ & $\begin{array}{l}0.072 \text { * } \\
0.037\end{array}$ & $\begin{array}{r}-0.003 \\
0.024\end{array}$ & $\begin{array}{r}-0.131 \\
0.082\end{array}$ & $\begin{array}{l}0.004 \\
0.032\end{array}$ & $\begin{array}{r}-0.065 \\
0.042\end{array}$ & $\begin{array}{l}0.021 \\
0.025\end{array}$ & $\begin{array}{l}0.011 \text { ** } \\
0.005\end{array}$ & $\begin{array}{c}-0.071 * \\
0.038\end{array}$ & $\begin{array}{r}-0.028 \\
0.158\end{array}$ & $\begin{array}{l}0.237 \text { ** } \\
0.092\end{array}$ & $\begin{array}{l}0.008 \\
0.051\end{array}$ & $\begin{array}{l}0.008 \\
0.014\end{array}$ & $\begin{array}{r}-0.022 \\
0.052\end{array}$ & $\begin{array}{r}-0.054 \\
0.051\end{array}$ \\
\hline relinc & $\begin{array}{r}-0.005 \\
0.009\end{array}$ & $\begin{array}{r}-0.008 \\
0.015\end{array}$ & $\begin{array}{l}0.008 \\
0.026\end{array}$ & $\begin{array}{r}-0.023 \\
0.060\end{array}$ & $\begin{array}{l}0.030 \\
0.021\end{array}$ & $\begin{array}{r}-0.024 \\
0.020\end{array}$ & $\begin{array}{r}-0.019 \\
0.016\end{array}$ & $\begin{array}{l}0.001 \\
0.008\end{array}$ & $\begin{array}{r}-0.008 \\
0.033\end{array}$ & $\begin{array}{r}-0.072 \\
0.050\end{array}$ & $\begin{array}{r}-0.073 \\
0.071\end{array}$ & $\begin{array}{l}0.014 \\
0.047\end{array}$ & $\begin{array}{l}0.018 \text { ** } \\
0.009\end{array}$ & $\begin{array}{l}0.083 \text { * } \\
0.040\end{array}$ & $\begin{array}{l}0.002 \\
0.019\end{array}$ \\
\hline$e d o$ & $\begin{array}{l}0.100 * \\
0.049\end{array}$ & $\begin{array}{l}0.214 \\
0.109\end{array}$ & + & $\dagger$ & $\begin{array}{l}0.154 \\
0.098\end{array}$ & $\begin{array}{r}-0.162 \\
0.132\end{array}$ & $\begin{array}{l}0.039 \\
0.109\end{array}$ & $\begin{array}{l}0.009 \\
0.039\end{array}$ & $\begin{array}{l}0.201 \\
0.158\end{array}$ & $\begin{array}{r}-0.036 \\
0.153\end{array}$ & $\begin{array}{l}0.245 \\
0.196\end{array}$ & $\begin{array}{r}-0.013 \\
0.264\end{array}$ & $\begin{array}{l}0.038 \\
0.104\end{array}$ & $\mathrm{f}(2)$ & $\mathrm{f}(1)$ \\
\hline edI & $\begin{array}{l}0.055 \text { ** } \\
0.026\end{array}$ & $\begin{array}{l}0.025 \\
0.050\end{array}$ & $\begin{array}{l}0.126 \star \star \star \\
0.054\end{array}$ & $\begin{array}{l}0.303 * \star \star \star \\
0.059\end{array}$ & $\begin{array}{l}0.076 \\
0.082\end{array}$ & $\begin{array}{l}0.003 \\
0.038\end{array}$ & $\begin{array}{l}0.027 \\
0.062\end{array}$ & $\begin{array}{l}0.013 \\
0.024\end{array}$ & $\begin{array}{l}0.063 \\
0.047\end{array}$ & $\begin{array}{r}-0.015 \\
0.114\end{array}$ & $\begin{array}{l}0.033 \\
0.087\end{array}$ & $\begin{array}{l}0.049 \\
0.049\end{array}$ & $\begin{array}{c}-0.099 * \star \star \\
0.019\end{array}$ & $\begin{array}{l}0.155 \\
0.093\end{array}$ & $\begin{array}{l}0.003 \\
0.038\end{array}$ \\
\hline ed 3 & $\begin{array}{l}-0.141 * \star \star \star \\
0.036\end{array}$ & $\begin{array}{r}-0.059 \\
0.125\end{array}$ & $\begin{array}{r}-0.052 \\
0.052\end{array}$ & $\begin{array}{l}-0.175 * * \\
0.078\end{array}$ & $\begin{array}{l}0.021 \\
0.110\end{array}$ & $\begin{array}{l}-0.064 * \star * \\
0.017\end{array}$ & $\begin{array}{l}-0.237 * * * \\
0.037\end{array}$ & $\begin{array}{l}-0.093 * \star * \\
0.038\end{array}$ & $\begin{array}{r}-0.052 \\
0.088\end{array}$ & $\begin{array}{r}-0.114 \\
0.249\end{array}$ & $\begin{array}{r}-0.170 \\
0.125\end{array}$ & $\begin{array}{c}-0.142 * \\
0.088\end{array}$ & $\begin{array}{c}-0.162 * \\
0.092\end{array}$ & $\begin{array}{r}-0.083 \\
0.123\end{array}$ & $\begin{array}{l}-0.282 \star \star \star \star \\
0.070\end{array}$ \\
\hline media & $\begin{array}{r}-0.010 \\
0.009\end{array}$ & $\begin{array}{l}0.005 \\
0.039\end{array}$ & $\begin{array}{r}-0.009 \\
0.023\end{array}$ & $\begin{array}{l}0.018 \\
0.039\end{array}$ & $\begin{array}{l}0.035 \\
0.032\end{array}$ & $\begin{array}{l}0.000 \\
0.021\end{array}$ & $\begin{array}{r}-0.018 \\
0.026\end{array}$ & $\begin{array}{r}-0.003 \\
0.012\end{array}$ & $\begin{array}{l}0.010 \\
0.019\end{array}$ & $\begin{array}{r}-0.075 \\
0.051\end{array}$ & $\begin{array}{l}0.020 \\
0.021\end{array}$ & $\begin{array}{l}0.003 \\
0.022\end{array}$ & $\begin{array}{r}-0.011 \\
0.028\end{array}$ & $\begin{array}{l}0.010 \\
0.026\end{array}$ & $\begin{array}{r}-0.021 \\
0.014\end{array}$ \\
\hline friendl & $\begin{array}{l}-0.121 * \star \star \\
0.019\end{array}$ & $\begin{array}{r}-0.001 \\
0.072\end{array}$ & $\begin{array}{l}-0.144 * \star \star \\
0.027\end{array}$ & $\begin{array}{l}0.047 \\
0.073\end{array}$ & $\begin{array}{c}-0.178 \star \star \star \\
0.074\end{array}$ & $\begin{array}{c}-0.132 \star * \\
0.062\end{array}$ & $\begin{array}{l}-0.137 * \star \star \\
0.051\end{array}$ & $\begin{array}{r}-0.032 \\
0.020\end{array}$ & $\begin{array}{r}-0.006 \\
0.058\end{array}$ & $\begin{array}{c}-0.230 * \star \\
0.110\end{array}$ & $\begin{array}{l}0.018 \\
0.101\end{array}$ & $\begin{array}{r}-0.056 \\
0.073\end{array}$ & $\begin{array}{c}-0.156 * \star \star \\
0.067\end{array}$ & $\begin{array}{l}0.033 \\
0.090\end{array}$ & $\begin{array}{r}-0.019 \\
0.048\end{array}$ \\
\hline friend 2 & $\begin{array}{l}-0.143 * * * \\
0.033\end{array}$ & $\begin{array}{l}-0.296 * \star * \\
0.085\end{array}$ & $\begin{array}{c}-0.139 * * * \\
0.039\end{array}$ & $\begin{array}{l}-0.299 * \star \star \\
0.097\end{array}$ & $\begin{array}{r}-0.136 \\
0.116\end{array}$ & $\begin{array}{l}-0.197 \text { ** } \\
0.096\end{array}$ & $\begin{array}{c}-0.147 \text { * } \\
0.081\end{array}$ & $\begin{array}{r}-0.064 \\
0.058\end{array}$ & $\begin{array}{c}-0.134 * \\
0.066\end{array}$ & $\begin{array}{r}-0.317 \\
0.155\end{array}$ & $\begin{array}{r}-0.006 \\
0.111\end{array}$ & $\begin{array}{c}-0.171 * \\
0.095\end{array}$ & $\begin{array}{c}-0.251 * \\
0.134\end{array}$ & $\begin{array}{l}0.121 \\
0.079\end{array}$ & $\begin{array}{r}-0.009 \\
0.089\end{array}$ \\
\hline racist & $\begin{array}{l}0.088 * \star \star \\
0.018\end{array}$ & $\begin{array}{l}0.002 \\
0.063\end{array}$ & $\begin{array}{l}0.103 * \star \star \\
0.035\end{array}$ & $\begin{array}{l}0.107 * \star \\
0.044\end{array}$ & $\begin{array}{c}-0.138 * \star \star \\
0.027\end{array}$ & $\begin{array}{r}-0.013 \\
0.022\end{array}$ & $\begin{array}{l}0.075 \\
0.053\end{array}$ & $\begin{array}{r}-0.001 \\
0.018\end{array}$ & $\begin{array}{l}0.089 * * \\
0.037\end{array}$ & $\begin{array}{l}0.184 * \star \\
0.076\end{array}$ & $\begin{array}{r}-0.093 \\
0.057\end{array}$ & $\begin{array}{l}0.198 * \star \star \\
0.054\end{array}$ & $\begin{array}{l}0.074 \text { ** } \\
0.039\end{array}$ & $\begin{array}{l}0.154 \star \star \star \\
0.044\end{array}$ & $\begin{array}{l}0.142 * * \star \\
0.036\end{array}$ \\
\hline citizen & $\begin{array}{l}0.087 \\
0.055\end{array}$ & $\begin{array}{l}0.341 \\
0.219\end{array}$ & $\begin{array}{l}0.232 \star \star \star \star \\
0.066\end{array}$ & $\begin{array}{c}-0.284 * \\
0.122\end{array}$ & $f(5)$ & $\begin{array}{l}0.264 * \star \star \\
0.082\end{array}$ & $\begin{array}{r}-0.077 \\
0.105\end{array}$ & $\begin{array}{l}0.165 * * \\
0.100\end{array}$ & $\begin{array}{r}-0.052 \\
0.102\end{array}$ & $\mathrm{f}(1)$ & $\begin{array}{l}0.247 \text { ** } \\
0.110\end{array}$ & $\begin{array}{r}-0.009 \\
0.215\end{array}$ & $\begin{array}{l}0.092 \\
0.187\end{array}$ & $\begin{array}{r}-0.188 \\
0.285\end{array}$ & $\begin{array}{l}0.047 \\
0.198\end{array}$ \\
\hline ethnic & $\begin{array}{c}-0.0922^{*} \\
0.049\end{array}$ & $\begin{array}{l}0.030 \\
0.090\end{array}$ & $\begin{array}{c}-0.189 * * \\
0.089\end{array}$ & $\begin{array}{l}0.194 \\
0.235\end{array}$ & $\begin{array}{r}-0.113 \\
0.120\end{array}$ & $\begin{array}{r}-0.214 \\
0.182\end{array}$ & $\begin{array}{l}0.004 \\
0.164\end{array}$ & $\begin{array}{l}-0.093 * \star * \\
0.028\end{array}$ & $\begin{array}{l}0.190 \\
0.340\end{array}$ & $\dagger$ & $\begin{array}{c}-0.295{ }^{*} \\
0.135\end{array}$ & $\begin{array}{l}0.066 \\
0.106\end{array}$ & $s(4)$ & $\begin{array}{l}0.333 \\
0.413\end{array}$ & $\begin{array}{r}-0.086 \\
0.083\end{array}$ \\
\hline fparent & $\begin{array}{l}-0.139 * \star \star \\
0.042\end{array}$ & $\begin{array}{l}0.137 \text { ** } \\
0.053\end{array}$ & $\begin{array}{l}0.026 \\
0.057\end{array}$ & $\begin{array}{l}0.036 \\
0.120\end{array}$ & $\begin{array}{l}0.196 \text { ** } \\
0.074\end{array}$ & $\begin{array}{r}-0.058 \\
0.057\end{array}$ & $\begin{array}{l}-0.248 * \star * \\
0.075\end{array}$ & $\begin{array}{l}-0.094 \star \star \star \star \\
0.040\end{array}$ & $\begin{array}{l}0.142 \\
0.104\end{array}$ & $\begin{array}{c}-0.377 * \\
0.157\end{array}$ & $\begin{array}{l}0.000 \\
0.099\end{array}$ & $\begin{array}{r}-0.058 \\
0.103\end{array}$ & $\begin{array}{r}-0.003 \\
0.176\end{array}$ & $\begin{array}{r}-0.076 \\
0.094\end{array}$ & $\begin{array}{l}-0.244 * \star \star \\
0.078\end{array}$ \\
\hline female & $\begin{array}{l}0.023 \\
0.018\end{array}$ & $\begin{array}{l}0.025 \\
0.051\end{array}$ & $\begin{array}{r}-0.036 \\
0.031\end{array}$ & $\begin{array}{r}-0.087 \\
0.065\end{array}$ & $\begin{array}{l}0.015 \\
0.050\end{array}$ & $\begin{array}{r}-0.019 \\
0.036\end{array}$ & 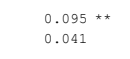 & $\begin{array}{r}-0.024 \\
0.023\end{array}$ & $\begin{array}{l}0.003 \\
0.042\end{array}$ & $\begin{array}{l}0.145 * \\
0.078\end{array}$ & $\begin{array}{l}0.047 \\
0.081\end{array}$ & $\begin{array}{l}0.008 \\
0.059\end{array}$ & $\begin{array}{l}0.054 \\
0.055\end{array}$ & $\begin{array}{l}0.042 \\
0.061\end{array}$ & $\begin{array}{l}0.017 \\
0.045\end{array}$ \\
\hline age & $\begin{array}{l}0.001 * \\
0.000\end{array}$ & $\begin{array}{l}0.002 \\
0.002\end{array}$ & $\begin{array}{l}0.001 * * \\
0.000\end{array}$ & $\begin{array}{l}0.000 \\
0.003\end{array}$ & $\begin{array}{l}0.000 \\
0.002\end{array}$ & $\begin{array}{l}0.005 * * \star \\
0.001\end{array}$ & $\begin{array}{l}0.002 \\
0.002\end{array}$ & $\begin{array}{l}0.001 * * * \\
0.000\end{array}$ & $\begin{array}{c}-0.002 * \\
0.001\end{array}$ & $\begin{array}{l}0.004 \\
0.004\end{array}$ & $\begin{array}{r}-0.001 \\
0.002\end{array}$ & $\begin{array}{c}-0.002 * \\
0.001\end{array}$ & $\begin{array}{l}0.005 * \star \star \\
0.001\end{array}$ & $\begin{array}{r}-0.002 \\
0.003\end{array}$ & $\begin{array}{l}0.000 \\
0.001\end{array}$ \\
\hline $\begin{array}{l}\text { log pseudol i kel ihood } \\
\text { McFadden's (1974) LRI } \\
\text { R² }^{2} \\
\text { Sum of PCP }\end{array}$ & $\begin{array}{r}-3882.747 \\
0.095 \\
0.168 \\
1.278\end{array}$ & $\begin{array}{r}-200.353 \\
0.094 \\
0.061 \\
1.173\end{array}$ & $\begin{array}{r}-483.255 \\
0.051 \\
0.139 \\
1.185\end{array}$ & $\begin{array}{r}-141.002 \\
0.114 \\
0.142 \\
1.217\end{array}$ & $\begin{array}{r}-158.387 \\
0.064 \\
0.189 \\
1.251\end{array}$ & $\begin{array}{r}-382.446 \\
0.068 \\
0.057 \\
1.141\end{array}$ & $\begin{array}{r}-321.579 \\
0.102 \\
0.232 \\
1.274\end{array}$ & $\begin{array}{r}-342.365 \\
0.096 \\
0.000 \\
1.049\end{array}$ & $\begin{array}{r}-338.664 \\
0.031 \\
0.057 \\
1.115\end{array}$ & $\begin{array}{r}-89.348 \\
0.134 \\
0.250 \\
1.277\end{array}$ & $\begin{array}{r}-144.803 \\
0.098 \\
0.080 \\
1.174\end{array}$ & $\begin{array}{r}-218.835 \\
0.062 \\
0.007 \\
1.104\end{array}$ & $\begin{array}{r}-226.539 \\
0.101 \\
-0.007 \\
1.102\end{array}$ & $\begin{array}{r}-119.628 \\
0.094 \\
0.052 \\
1.101\end{array}$ & $\begin{array}{r}-335.060 \\
0.118 \\
0.158 \\
1.260\end{array}$ \\
\hline obs. & 6311.000 & 375.000 & 735.000 & 231.000 & 259.000 & 656.000 & 519.000 & 1007.000 & 517.000 & 149.000 & 233.000 & 362.000 & 423.000 & 242.000 & 590.000 \\
\hline
\end{tabular}

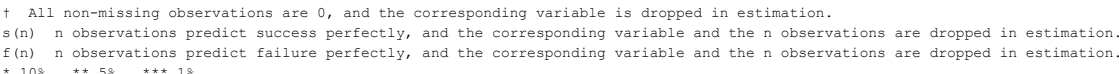

The three goodness-of-fit measures are described in Verbeek (2004: 194-197). Sum of PCP is the sum of the proportions of correct predictions for anti $=1$ and anti $=0$.

Sampling weights provided by ESS are applied in maximum likelihood estimation.
Eor EU, a further weight adjustment is made to reflect the population size of each country.

Estimated standard errors are based on the assumption that observations are not necessarily independent within each region of a country, but are independent across regions of the country

For EU, 13 country durnies are included with UK being the reference. 
Table 6

(b) Probit estimates of marginal effects evaluated at the means of explanatory variables: those who did not think that immigration would depress wages on average

\begin{tabular}{|c|c|c|c|c|c|c|c|c|c|c|c|c|c|c|c|}
\hline & EU & AT & $\mathrm{DE}$ & DK & ES & EI & FR & GR & IE & IT & $\mathrm{LU}$ & $\mathrm{NL}$ & PT & SE & UK \\
\hline employ & $\begin{array}{l}0.043 \text { ** } \\
0.021\end{array}$ & $\begin{array}{c}-0.267 * \star \star \\
0.061\end{array}$ & $\begin{array}{l}0.001 \\
0.036\end{array}$ & $\begin{array}{r}-0.004 \\
0.073\end{array}$ & $\begin{array}{l}0.138 * \star \star \\
0.051\end{array}$ & $\begin{array}{l}0.020 \\
0.067\end{array}$ & $\begin{array}{r}-0.007 \\
0.074\end{array}$ & $\begin{array}{l}0.106 \\
0.091\end{array}$ & $\begin{array}{l}0.048 \\
0.033\end{array}$ & $\begin{array}{l}0.064 \\
0.056\end{array}$ & $\begin{array}{l}0.083 \\
0.111\end{array}$ & $\begin{array}{l}0.073 \\
0.049\end{array}$ & $\begin{array}{l}0.010 \\
0.100\end{array}$ & $\begin{array}{l}0.067 * \star \star \\
0.023\end{array}$ & $\begin{array}{l}0.121 * * \\
0.059\end{array}$ \\
\hline unemploy & $\begin{array}{l}0.008 \\
0.040\end{array}$ & $\begin{array}{r}-0.021 \\
0.104\end{array}$ & $\begin{array}{l}0.045 \\
0.080\end{array}$ & $\begin{array}{r}-0.053 \\
0.110\end{array}$ & $\begin{array}{r}-0.026 \\
0.042\end{array}$ & $\begin{array}{l}0.062 \\
0.069\end{array}$ & $\begin{array}{l}0.047 \\
0.107\end{array}$ & $\begin{array}{l}0.036 \\
0.134\end{array}$ & $\begin{array}{r}-0.053 \\
0.065\end{array}$ & $\begin{array}{l}0.003 \\
0.120\end{array}$ & $\begin{array}{r}-0.223 \\
0.168\end{array}$ & $\begin{array}{c}-0.154 * \\
0.073\end{array}$ & $\begin{array}{r}-0.173 \\
0.199\end{array}$ & $\begin{array}{l}0.021 \\
0.051\end{array}$ & $\begin{array}{r}-0.017 \\
0.125\end{array}$ \\
\hline isb & $\begin{array}{r}-0.007 \\
0.013\end{array}$ & $\begin{array}{l}0.051 \\
0.057\end{array}$ & $\begin{array}{l}0.059 * \star \star \\
0.021\end{array}$ & $\begin{array}{l}0.016 \\
0.047\end{array}$ & $\begin{array}{r}-0.035 \\
0.031\end{array}$ & $\begin{array}{l}-0.063 * \star \star \star \\
0.022\end{array}$ & $\begin{array}{l}0.000 \\
0.029\end{array}$ & $\begin{array}{r}-0.002 \\
0.019\end{array}$ & $\begin{array}{r}-0.002 \\
0.021\end{array}$ & $\begin{array}{r}-0.106 \\
0.075\end{array}$ & $\begin{array}{l}0.178 \text { ** } \\
0.083\end{array}$ & $\begin{array}{l}0.038 \text { * } \\
0.022\end{array}$ & $\begin{array}{r}-0.081 \\
0.056\end{array}$ & $\begin{array}{r}-0.011 \\
0.019\end{array}$ & $\begin{array}{r}-0.097 \\
0.064\end{array}$ \\
\hline relinc & $\begin{array}{r}-0.008 \\
0.006\end{array}$ & $\begin{array}{r}-0.006 \\
0.032\end{array}$ & $\begin{array}{l}0.001 \\
0.007\end{array}$ & $\begin{array}{r}-0.025 \\
0.029\end{array}$ & $\begin{array}{r}-0.030 \\
0.040\end{array}$ & $\begin{array}{l}0.014 \\
0.010\end{array}$ & $\begin{array}{r}-0.018 \\
0.017\end{array}$ & $\begin{array}{c}-0.030 * \\
0.018\end{array}$ & $\begin{array}{l}0.002 \\
0.018\end{array}$ & $\begin{array}{r}-0.027 \\
0.025\end{array}$ & $\begin{array}{l}0.043 \\
0.047\end{array}$ & $\begin{array}{r}-0.012 \\
0.017\end{array}$ & $\begin{array}{r}-0.024 \\
0.017\end{array}$ & $\begin{array}{r}-0.011 \\
0.011\end{array}$ & $\begin{array}{r}-0.003 \\
0.012\end{array}$ \\
\hline edo & $\begin{array}{l}0.069 \\
0.052\end{array}$ & $\begin{array}{l}0.166 \\
0.300\end{array}$ & † & $\mathrm{s}(1)$ & $\begin{array}{l}0.012 \\
0.140\end{array}$ & $\begin{array}{l}0.201 \\
0.176\end{array}$ & $\begin{array}{l}0.115 \\
0.090\end{array}$ & $\begin{array}{r}-0.052 \\
0.136\end{array}$ & $\begin{array}{l}0.231 * \star \\
0.116\end{array}$ & $\begin{array}{l}0.243 \\
0.349\end{array}$ & $f(1)$ & $\begin{array}{r}-0.133 \\
0.149\end{array}$ & $\begin{array}{l}0.277 \text { ** } \\
0.126\end{array}$ & $f(8)$ & $\dagger$ \\
\hline edI & $\begin{array}{l}0.079 * \star \star \\
0.019\end{array}$ & $\begin{array}{l}0.034 \\
0.039\end{array}$ & $\begin{array}{l}0.050 \\
0.043\end{array}$ & $\begin{array}{l}0.067 \\
0.041\end{array}$ & $\begin{array}{r}-0.023 \\
0.072\end{array}$ & $\begin{array}{l}0.024 \\
0.043\end{array}$ & $\begin{array}{l}0.123 * * \\
0.056\end{array}$ & $\begin{array}{l}0.049 \\
0.079\end{array}$ & $\begin{array}{l}0.058 \text { * } \\
0.034\end{array}$ & $\begin{array}{l}0.212 * \star \star \\
0.050\end{array}$ & $\begin{array}{l}0.089 \\
0.076\end{array}$ & $\begin{array}{l}0.025 \\
0.044\end{array}$ & $\begin{array}{l}0.053 \\
0.037\end{array}$ & $\begin{array}{l}0.024 * * \\
0.013\end{array}$ & $\begin{array}{l}0.104 * \star \star \\
0.034\end{array}$ \\
\hline ed3 & $\begin{array}{l}-0.081 * * \star \\
0.019\end{array}$ & $\begin{array}{r}-0.054 \\
0.048\end{array}$ & $\begin{array}{c}-0.094 * * \star \\
0.031\end{array}$ & $\begin{array}{c}-0.146 * \star \star \star \\
0.041\end{array}$ & $\begin{array}{l}0.064 \\
0.087\end{array}$ & $\begin{array}{c}-0.102 \star \star \\
0.050\end{array}$ & $\begin{array}{r}-0.020 \\
0.047\end{array}$ & $\begin{array}{c}-0.103 * \star \\
0.047\end{array}$ & $\begin{array}{l}-0.075 * * \star \\
0.025\end{array}$ & $\begin{array}{l}0.027 \\
0.112\end{array}$ & $\begin{array}{r}-0.066 \\
0.087\end{array}$ & $\begin{array}{c}-0.151 * * * \\
0.030\end{array}$ & $\begin{array}{l}0.037 \\
0.095\end{array}$ & $\begin{array}{l}-0.048 * \star \star \star \\
0.006\end{array}$ & $\begin{array}{c}-0.150 * \star \star \star \\
0.041\end{array}$ \\
\hline media & $\begin{array}{c}-0.015 * * \\
0.007\end{array}$ & $\begin{array}{l}0.000 \\
0.023\end{array}$ & $\begin{array}{l}-0.028 * \star \star \\
0.010\end{array}$ & $\begin{array}{l}-0.027 \text { ** } \\
0.013\end{array}$ & $\begin{array}{l}0.028 \\
0.026\end{array}$ & $\begin{array}{l}0.014 \\
0.015\end{array}$ & $\begin{array}{c}-0.037 \text { * } \\
0.021\end{array}$ & $\begin{array}{c}-0.082 * \star \\
0.038\end{array}$ & $\begin{array}{r}-0.017 \\
0.013\end{array}$ & $\begin{array}{l}0.050 * \star \\
0.021\end{array}$ & $\begin{array}{r}-0.022 \\
0.021\end{array}$ & $\begin{array}{l}0.012 \\
0.010\end{array}$ & $\begin{array}{r}-0.009 \\
0.027\end{array}$ & $\begin{array}{l}0.000 \\
0.003\end{array}$ & $\begin{array}{l}-0.045 * \star \star \star \\
0.014\end{array}$ \\
\hline friendl & $\begin{array}{l}-0.085 * \star \star \star \\
0.014\end{array}$ & $\begin{array}{c}-0.209 * \star \star \star \\
0.043\end{array}$ & $\begin{array}{c}-0.100 * * \star \star \\
0.019\end{array}$ & $\begin{array}{c}-0.127 * * * \\
0.030\end{array}$ & $\begin{array}{c}-0.127 * * * \\
0.038\end{array}$ & $\begin{array}{c}-0.098 * * \\
0.039\end{array}$ & $\begin{array}{c}-0.074 * \\
0.040\end{array}$ & $\begin{array}{c}-0.213 * * \\
0.090\end{array}$ & $\begin{array}{r}-0.015 \\
0.028\end{array}$ & $\begin{array}{r}-0.072 \\
0.049\end{array}$ & $\begin{array}{l}0.026 \\
0.090\end{array}$ & $\begin{array}{c}-0.067 * * * \\
0.024\end{array}$ & $\begin{array}{r}-0.046 \\
0.099\end{array}$ & $\begin{array}{r}-0.001 \\
0.020\end{array}$ & $\begin{array}{c}-0.075 * \star \\
0.033\end{array}$ \\
\hline friend2 & $\begin{array}{l}-0.179 * \star \star \\
0.018\end{array}$ & $\begin{array}{l}-0.300 * \star \star \\
0.035\end{array}$ & $\begin{array}{c}-0.164 * \star \star \\
0.044\end{array}$ & $\begin{array}{c}-0.243 * \star \\
0.077\end{array}$ & $\begin{array}{c}-0.321 * * * \\
0.059\end{array}$ & $\begin{array}{c}-0.347 * * \star \\
0.015\end{array}$ & $\begin{array}{l}-0.211 * * \star \\
0.033\end{array}$ & $\begin{array}{c}-0.175 * \\
0.092\end{array}$ & $\begin{array}{l}-0.120 * \star \star \\
0.016\end{array}$ & $\begin{array}{r}-0.185 \\
0.048\end{array}$ & $\begin{array}{l}0.075 \\
0.087\end{array}$ & $\begin{array}{l}-0.068 \text { * } \\
0.035\end{array}$ & $\begin{array}{c}-0.226 * * * \\
0.047\end{array}$ & $\begin{array}{l}-0.046 * \star * \\
0.015\end{array}$ & $\begin{array}{c}-0.108 * * \\
0.048\end{array}$ \\
\hline racist & $\begin{array}{l}0.139 * \star \star \\
0.015\end{array}$ & $\begin{array}{l}0.005 \\
0.024\end{array}$ & $\begin{array}{l}0.116 * \star \star \\
0.030\end{array}$ & $\begin{array}{l}0.127 * \star \star \\
0.029\end{array}$ & $\begin{array}{l}0.123 * \star \star \\
0.041\end{array}$ & $\begin{array}{l}0.039 \\
0.034\end{array}$ & $\begin{array}{l}0.169 * \star \star \star \\
0.035\end{array}$ & $\begin{array}{l}0.146 \text { * } \\
0.076\end{array}$ & $\begin{array}{l}0.103 * \star \star \star \\
0.032\end{array}$ & $\begin{array}{l}0.114 * \star \\
0.054\end{array}$ & $\begin{array}{l}0.046 \\
0.055\end{array}$ & $\begin{array}{l}0.125 * \star \star \\
0.037\end{array}$ & $\begin{array}{l}0.159 * \star \\
0.076\end{array}$ & $\begin{array}{l}0.090 * \star \star \\
0.013\end{array}$ & $\begin{array}{l}0.223 * \star \star \\
0.041\end{array}$ \\
\hline citizen & $\begin{array}{l}0.066 \text { * } \\
0.033\end{array}$ & $\begin{array}{r}-0.192 \\
0.126\end{array}$ & $\begin{array}{l}0.084 \\
0.048\end{array}$ & $\begin{array}{l}0.174 \\
0.109\end{array}$ & $\begin{array}{l}0.102 \\
0.154\end{array}$ & $\begin{array}{l}0.020 \\
0.139\end{array}$ & $\begin{array}{r}-0.073 \\
0.125\end{array}$ & $\begin{array}{l}0.219 * * \\
0.102\end{array}$ & $\begin{array}{l}0.156 * \star \star \\
0.032\end{array}$ & $\neq$ & $\begin{array}{r}-0.117 \\
0.103\end{array}$ & $\begin{array}{r}-0.087 \\
0.124\end{array}$ & $\begin{array}{l}0.068 \\
0.158\end{array}$ & $\begin{array}{r}-0.010 \\
0.032\end{array}$ & $\begin{array}{l}0.149 \\
0.096\end{array}$ \\
\hline ethnic & $\begin{array}{l}0.070 \\
0.045\end{array}$ & $\begin{array}{l}0.130 * \star \\
0.058\end{array}$ & $\begin{array}{r}-0.035 \\
0.093\end{array}$ & $\begin{array}{l}0.125 \\
0.133\end{array}$ & $f(9)$ & $\mathrm{f}(5)$ & $\begin{array}{l}0.108 \\
0.116\end{array}$ & $\begin{array}{r}-0.098 \\
0.135\end{array}$ & $\begin{array}{r}-0.153 \\
0.064\end{array}$ & $\begin{array}{l}0.605 * \star \\
0.243\end{array}$ & $\begin{array}{r}-0.091 \\
0.142\end{array}$ & $\begin{array}{l}0.054 \\
0.061\end{array}$ & $\begin{array}{r}-0.163 \\
0.163\end{array}$ & $\begin{array}{r}-0.011 \\
0.049\end{array}$ & $\begin{array}{l}0.120 \\
0.127\end{array}$ \\
\hline fparent & $\begin{array}{l}0.006 \\
0.019\end{array}$ & $\begin{array}{r}-0.036 \\
0.036\end{array}$ & $\begin{array}{l}0.029 \\
0.048\end{array}$ & $\begin{array}{l}0.019 \\
0.068\end{array}$ & $\begin{array}{r}-0.065 \\
0.119\end{array}$ & $\begin{array}{l}0.192 * \star \\
0.085\end{array}$ & $\begin{array}{r}-0.024 \\
0.028\end{array}$ & $\begin{array}{r}-0.009 \\
0.073\end{array}$ & $\begin{array}{l}0.065 \\
0.066\end{array}$ & $\begin{array}{c}-0.121 \\
0.071\end{array}$ & $\begin{array}{c}-0.165 \text { * } \\
0.084\end{array}$ & $\begin{array}{c}-0.086 * * \\
0.039\end{array}$ & $\begin{array}{r}-0.141 \\
0.172\end{array}$ & $\begin{array}{l}0.052 \text { * } \\
0.034\end{array}$ & $\begin{array}{l}0.039 \\
0.057\end{array}$ \\
\hline female & $\begin{array}{r}-0.008 \\
0.013\end{array}$ & $\begin{array}{l}0.000 \\
0.036\end{array}$ & $\begin{array}{c}-0.040 * \star \\
0.019\end{array}$ & $\begin{array}{r}-0.038 \\
0.040\end{array}$ & $\begin{array}{l}0.045 \\
0.043\end{array}$ & $\begin{array}{l}-0.124 * \star \star \star \\
0.025\end{array}$ & $\begin{array}{l}0.000 \\
0.053\end{array}$ & $\begin{array}{c}-0.134 * \\
0.067\end{array}$ & $\begin{array}{l}-0.073 * \star \star \\
0.026\end{array}$ & $\begin{array}{l}0.014 \\
0.053\end{array}$ & $\begin{array}{r}-0.015 \\
0.063\end{array}$ & $\begin{array}{r}-0.022 \\
0.026\end{array}$ & $\begin{array}{l}0.080 \\
0.077\end{array}$ & $\begin{array}{c}-0.035 * * \\
0.016\end{array}$ & $\begin{array}{l}0.020 \\
0.025\end{array}$ \\
\hline age & $\begin{array}{l}0.001 * * \\
0.000\end{array}$ & $\begin{array}{l}0.006 \text { ** } \\
0.002\end{array}$ & $\begin{array}{l}0.001 \\
0.001\end{array}$ & $\begin{array}{l}0.004 \star \star \star \\
0.001\end{array}$ & $\begin{array}{r}-0.001 \\
0.002\end{array}$ & $\begin{array}{l}0.008 * \star \star \\
0.001\end{array}$ & $\begin{array}{l}0.003 \text { * } \\
0.001\end{array}$ & $\begin{array}{l}0.002 \\
0.002\end{array}$ & $\begin{array}{l}0.000 \\
0.000\end{array}$ & $\begin{array}{r}-0.002 \\
0.002\end{array}$ & $\begin{array}{l}0.002 \\
0.002\end{array}$ & $\begin{array}{l}0.000 \\
0.000\end{array}$ & $\begin{array}{l}0.000 \\
0.002\end{array}$ & $\begin{array}{l}0.000 \\
0.000\end{array}$ & $\begin{array}{l}0.000 \\
0.000\end{array}$ \\
\hline $\begin{array}{l}\text { log pseudolikelihood } \\
\text { McFadden's (1974) LRI } \\
\mathrm{R}^{2} \mathrm{P} \\
\text { Sum of PCP }\end{array}$ & $\begin{array}{r}-5908.291 \\
0.095 \\
0.115 \\
1.224\end{array}$ & $\begin{array}{r}-414.856 \\
0.113 \\
0.294 \\
1.344\end{array}$ & $\begin{array}{r}-602.884 \\
0.082 \\
0.019 \\
1.090\end{array}$ & $\begin{array}{r}-559.429 \\
0.085 \\
0.173 \\
1.252\end{array}$ & $\begin{array}{r}-266.638 \\
0.067 \\
0.122 \\
1.207\end{array}$ & $\begin{array}{r}-587.701 \\
0.138 \\
0.309 \\
1.358\end{array}$ & $\begin{array}{r}-311.578 \\
0.116 \\
0.118 \\
1.223\end{array}$ & $\begin{array}{r}-147.760 \\
0.127 \\
0.175 \\
1.250\end{array}$ & $\begin{array}{r}-423.550 \\
0.073 \\
0.046 \\
1.071\end{array}$ & $\begin{array}{r}-148.456 \\
0.102 \\
0.057 \\
1.089\end{array}$ & $\begin{array}{r}-202.712 \\
0.059 \\
0.066 \\
1.148\end{array}$ & $\begin{array}{r}-853.079 \\
0.043 \\
-0.004 \\
1.041\end{array}$ & $\begin{array}{r}-238.116 \\
0.088 \\
0.158 \\
1.183\end{array}$ & $\begin{array}{r}-404.340 \\
0.097 \\
0.007 \\
1.019\end{array}$ & $\begin{array}{r}-579.029 \\
0.129 \\
0.149 \\
1.235\end{array}$ \\
\hline obs. & 10657.000 & 677.000 & 1148.000 & 901.000 & 423.000 & 989.000 & 582.000 & 248.000 & 856.000 & 313.000 & 316.000 & 1406.000 & 379.000 & 1356.000 & 1039.000 \\
\hline
\end{tabular}

I A11 non-missing observations are 0 , and the corresponding variable is dropped in estimation.
$\neq$ All non-missing observations are 1 , and the corresponding variable is dropped in estimation.

$s(n)$ nobservations predict success perfectly, and the corresponding variable and the $n$ observations are dropped in estimation.
$f(n) \quad n$ observations predict failure perfectly, and the corresponding variable and the $n$ observations

The three goodness-of-fit measures are described in verbeek (2004: 194-197). Sum of PCP is the sum of the proportions of correct predictions for anti $=1$ and anti $=0$.

Sampling weights provided by ESS are applied in maximum likelihood estimation.

Estimated standard errors are based on the assumption that observations are not necessarily independent within each region of a country, but are independent across regions of the country.

For EU, 13 country durnies are included with UK being the reference. 
(a) Probit estimates of marginal effects evaluated at the means of explanatory variables: those who thought that immigration would depress wages on average

\begin{tabular}{|c|c|c|c|c|c|c|c|c|c|c|c|c|c|c|c|}
\hline & $\mathrm{EU}_{\mathrm{EU}}$ & $\mathrm{AT}_{\mathrm{AT}}$ & $\mathrm{DE}$ & $\mathrm{DK}$ & ES & $\mathrm{FI}^{\mathrm{FI}}$ & FR & GR & $\mathrm{IE}$ & IT & LU & $\mathrm{NL}^{\mathrm{N}}$ & $\mathrm{PT}$ & SE & UK \\
\hline employ & $\begin{array}{r}-0.043 \\
0.055\end{array}$ & $\begin{array}{c}-0.448 * \star \star \star \\
0.161\end{array}$ & $\begin{array}{r}-0.092 \\
0.147\end{array}$ & $\begin{array}{l}0.088 \\
0.294\end{array}$ & $\begin{array}{r}-0.197 \\
0.155\end{array}$ & $\begin{array}{r}-0.019 \\
0.158\end{array}$ & $\begin{array}{r}-0.009 \\
0.158\end{array}$ & $\begin{array}{r}-0.019 \\
0.025\end{array}$ & $\begin{array}{r}-0.083 \\
0.104\end{array}$ & $\begin{array}{l}0.0661 \\
0.370\end{array}$ & $\begin{array}{l}0.338 \\
0.187\end{array}$ & $\begin{array}{l}0.188 \\
0.186\end{array}$ & $\begin{array}{l}0.106 \\
0.052\end{array}$ & $\begin{array}{l}0.237 \\
0.373\end{array}$ & $\begin{array}{r}-0.218 \\
0.213\end{array}$ \\
\hline employ $\times$ isb & $\begin{array}{l}0.038 \\
0.042\end{array}$ & $\begin{array}{l}0.250 * * \\
0.126\end{array}$ & $\begin{array}{l}0.025 \\
0.131\end{array}$ & $\begin{array}{c}-0.089 \\
0.219\end{array}$ & $\begin{array}{l}0.061 \\
0.107\end{array}$ & $\begin{array}{l}0.023 \\
0.137\end{array}$ & $\begin{array}{l}0.085 \\
0.094\end{array}$ & $\begin{array}{l}0.018 \\
0.019\end{array}$ & $\begin{array}{l}0.133 \\
0.128\end{array}$ & $\begin{array}{l}0.011 \\
0.312\end{array}$ & $\begin{array}{c}-0.454 \text { * } \\
0.265\end{array}$ & $\begin{array}{r}-0.115 \\
0.202\end{array}$ & $\begin{array}{c}-0.086 \text { * } \\
0.044\end{array}$ & $\begin{array}{r}-0.228 \\
0.213\end{array}$ & $\begin{array}{l}0.210 \\
0.206\end{array}$ \\
\hline unemploy & $\begin{array}{l}0.117 \text { ** } \\
0.055\end{array}$ & $\begin{array}{l}0.099 \\
0.194\end{array}$ & $\begin{array}{l}0.040 \\
0.130\end{array}$ & $\begin{array}{r}-0.570 \\
0.113\end{array}$ & $\begin{array}{l}0.271 \text { * } \\
0.102\end{array}$ & $\begin{array}{r}-0.091 \\
0.130\end{array}$ & $\begin{array}{l}0.244 \star \star \star \\
0.084\end{array}$ & $\begin{array}{r}-0.080 \\
0.122\end{array}$ & $\begin{array}{r}-0.058 \\
0.282\end{array}$ & $\begin{array}{l}-0.631 * * * \\
0.069\end{array}$ & $\Delta$ & $\begin{array}{l}0.326 \\
0.064\end{array}$ & $\begin{array}{l}0.055 \\
0.184\end{array}$ & $\begin{array}{l}0.114 \\
0.353\end{array}$ & $\begin{array}{l}0.143 \\
0.180\end{array}$ \\
\hline unemploy $\mathrm{x}$ isb & $\begin{array}{c}-0.025 \\
0.043\end{array}$ & $\begin{array}{r}-0.073 \\
0.183\end{array}$ & $\begin{array}{l}0.053 \\
0.087\end{array}$ & $\begin{array}{l}1.011 \\
0.691\end{array}$ & $\begin{array}{c}-0.146 \text { ** } \\
0.073\end{array}$ & $\begin{array}{l}0.122 \\
0.084\end{array}$ & $\begin{array}{l}-0.155 * * \\
0.065\end{array}$ & $\begin{array}{l}0.047 \\
0.035\end{array}$ & $\begin{array}{l}0.060 \\
0.263\end{array}$ & $\begin{array}{l}1.413 * \star \star \\
0.328\end{array}$ & $\Delta$ & $\begin{array}{r}-0.412 \\
0.349\end{array}$ & $\begin{array}{r}-0.174 \\
0.140\end{array}$ & $\begin{array}{r}-0.236 \\
0.222\end{array}$ & $\begin{array}{r}-0.195 \\
0.202\end{array}$ \\
\hline$i s b$ & $\begin{array}{l}0.004 \\
0.013\end{array}$ & $\begin{array}{l}0.025 \\
0.038\end{array}$ & $\begin{array}{r}-0.015 \\
0.033\end{array}$ & $\begin{array}{r}-0.133 \\
0.081\end{array}$ & $\begin{array}{l}0.016 \\
0.029\end{array}$ & $\begin{array}{c}-0.083 * \star \\
0.039\end{array}$ & $\begin{array}{l}0.024 \\
0.021\end{array}$ & $\begin{array}{l}0.004 \\
0.004\end{array}$ & $\begin{array}{l}-0.097 * * \\
0.047\end{array}$ & $\begin{array}{r}-0.103 \\
0.177\end{array}$ & $\begin{array}{l}0.265 * \star \star \\
0.098\end{array}$ & $\begin{array}{l}0.026 \\
0.057\end{array}$ & $\begin{array}{l}0.026 \\
0.020\end{array}$ & $\begin{array}{l}0.015 \\
0.048\end{array}$ & $\begin{array}{r}-0.065 \\
0.061\end{array}$ \\
\hline relinc & $\begin{array}{r}-0.004 \\
0.009\end{array}$ & $\begin{array}{r}-0.015 \\
0.011\end{array}$ & $\begin{array}{l}0.007 \\
0.025\end{array}$ & $\begin{array}{r}-0.023 \\
0.059\end{array}$ & $\begin{array}{l}0.035 \\
0.022\end{array}$ & $\begin{array}{r}-0.024 \\
0.020\end{array}$ & $\begin{array}{r}-0.019 \\
0.016\end{array}$ & $\begin{array}{l}0.001 \\
0.008\end{array}$ & $\begin{array}{c}-0.014 \\
0.027\end{array}$ & $\begin{array}{r}-0.073 \\
0.045\end{array}$ & $\begin{array}{r}-0.073 \\
0.071\end{array}$ & $\begin{array}{l}0.016 \\
0.047\end{array}$ & $\begin{array}{l}0.025 * \star \star \\
0.009\end{array}$ & $\begin{array}{l}0.094 * \star \\
0.041\end{array}$ & $\begin{array}{l}0.000 \\
0.020\end{array}$ \\
\hline edo & $\begin{array}{l}0.100 * \\
0.049\end{array}$ & $\begin{array}{l}0.218 \\
0.099\end{array}$ & t & † & $\begin{array}{l}0.138 \\
0.095\end{array}$ & $\begin{array}{r}-0.174 \\
0.136\end{array}$ & $\begin{array}{l}0.041 \\
0.109\end{array}$ & $\begin{array}{l}0.012 \\
0.037\end{array}$ & $\begin{array}{l}0.204 \\
0.160\end{array}$ & $\begin{array}{r}-0.012 \\
0.163\end{array}$ & $\begin{array}{l}0.245 \\
0.195\end{array}$ & $\begin{array}{r}-0.012 \\
0.263\end{array}$ & $\begin{array}{l}0.046 \\
0.105\end{array}$ & $f(2)$ & $f(1)$ \\
\hline edr & $\begin{array}{l}0.054 \text { ** } \\
0.026\end{array}$ & $\begin{array}{l}0.024 \\
0.049\end{array}$ & $\begin{array}{l}0.128 * * \\
0.055\end{array}$ & $\begin{array}{l}0.303 * \star \star \star \\
0.059\end{array}$ & $\begin{array}{l}0.064 \\
0.079\end{array}$ & $\begin{array}{l}0.002 \\
0.037\end{array}$ & $\begin{array}{l}0.028 \\
0.062\end{array}$ & $\begin{array}{l}0.014 \\
0.025\end{array}$ & $\begin{array}{l}0.068 \\
0.049\end{array}$ & $\begin{array}{r}-0.023 \\
0.118\end{array}$ & $\begin{array}{l}0.040 \\
0.088\end{array}$ & $\begin{array}{l}0.047 \\
0.049\end{array}$ & $\begin{array}{c}-0.094 * \star \star \star \\
0.017\end{array}$ & $\begin{array}{l}0.149 \\
0.094\end{array}$ & $\begin{array}{r}-0.002 \\
0.039\end{array}$ \\
\hline ed3 & $\begin{array}{l}-0.142 * * \star \star \\
0.036\end{array}$ & $\begin{array}{r}-0.066 \\
0.134\end{array}$ & $\begin{array}{r}-0.052 \\
0.052\end{array}$ & $\begin{array}{l}-0.170 * * \\
0.083\end{array}$ & $\begin{array}{r}-0.001 \\
0.110\end{array}$ & $\begin{array}{l}-0.065 * * * \\
0.017\end{array}$ & $\begin{array}{l}-0.241 * * * \\
0.035\end{array}$ & $\begin{array}{l}-0.092 * * * \\
0.040\end{array}$ & $\begin{array}{r}-0.054 \\
0.088\end{array}$ & $\begin{array}{r}-0.103 \\
0.244\end{array}$ & $\begin{array}{r}-0.151 \\
0.126\end{array}$ & $\begin{array}{c}-0.142 \text { * } \\
0.087\end{array}$ & $\begin{array}{c}-0.162 * \\
0.089\end{array}$ & $\begin{array}{c}-0.090 \\
0.121\end{array}$ & $\begin{array}{l}-0.286 * \star \star \star \\
0.068\end{array}$ \\
\hline media & $\begin{array}{r}-0.010 \\
0.009\end{array}$ & $\begin{array}{l}0.005 \\
0.040\end{array}$ & $\begin{array}{r}-0.009 \\
0.022\end{array}$ & $\begin{array}{l}0.017 \\
0.038\end{array}$ & $\begin{array}{l}0.036 \\
0.032\end{array}$ & $\begin{array}{l}0.000 \\
0.021\end{array}$ & $\begin{array}{c}-0.018 \\
0.026\end{array}$ & $\begin{array}{r}-0.003 \\
0.012\end{array}$ & $\begin{array}{l}0.010 \\
0.020\end{array}$ & $\begin{array}{c}-0.087 \text { * } \\
0.051\end{array}$ & $\begin{array}{l}0.021 \\
0.021\end{array}$ & $\begin{array}{l}0.005 \\
0.024\end{array}$ & $\begin{array}{r}-0.012 \\
0.027\end{array}$ & $\begin{array}{l}0.014 \\
0.025\end{array}$ & $\begin{array}{c}-0.022 \\
0.014\end{array}$ \\
\hline friendl & $\begin{array}{l}-0.122 \text { *** } \\
0.019\end{array}$ & $\begin{array}{l}0.000 \\
0.073\end{array}$ & $\begin{array}{l}-0.143 * \star * \star \\
0.026\end{array}$ & $\begin{array}{l}0.037 \\
0.075\end{array}$ & $\begin{array}{c}-0.185 \text { ** } \\
0.077\end{array}$ & $\begin{array}{l}-0.132 * \star \\
0.064\end{array}$ & $\begin{array}{l}-0.135 * \star \star \\
0.051\end{array}$ & $\begin{array}{r}-0.033 \\
0.021\end{array}$ & $\begin{array}{r}-0.006 \\
0.059\end{array}$ & $\begin{array}{c}-0.211 \text { * } \\
0.106\end{array}$ & $\begin{array}{l}0.029 \\
0.103\end{array}$ & $\begin{array}{r}-0.059 \\
0.072\end{array}$ & $\begin{array}{l}-0.157 * \star \star \star \\
0.066\end{array}$ & $\begin{array}{l}0.026 \\
0.084\end{array}$ & $\begin{array}{r}-0.019 \\
0.047\end{array}$ \\
\hline friendz & $\begin{array}{l}-0.144 \star \star \star \star \\
0.033\end{array}$ & $\begin{array}{l}-0.324 * \star \star \star \\
0.083\end{array}$ & $\begin{array}{l}-0.139 * \star \star \\
0.040\end{array}$ & $\begin{array}{c}-0.315 * \star \star \star \\
0.096\end{array}$ & $\begin{array}{r}-0.140 \\
0.114\end{array}$ & $\begin{array}{c}-0.197 * \star \\
0.094\end{array}$ & $\begin{array}{c}-0.142 \text { * } \\
0.081\end{array}$ & $\begin{array}{c}-0.061 \\
0.054\end{array}$ & $\begin{array}{c}-0.135 \\
0.066\end{array}$ & $\begin{array}{r}-0.311 \\
0.171\end{array}$ & $\begin{array}{l}0.007 \\
0.112\end{array}$ & $\begin{array}{c}-0.173 \\
0.095\end{array}$ & $\begin{array}{c}-0.265 \star * \star \\
0.136\end{array}$ & $\begin{array}{l}0.115 \\
0.075\end{array}$ & $\begin{array}{r}-0.016 \\
0.089\end{array}$ \\
\hline racist & $\begin{array}{l}0.088 * \star \star \\
0.018\end{array}$ & $\begin{array}{l}0.008 \\
0.064\end{array}$ & $\begin{array}{l}0.101 * \star \star \\
0.033\end{array}$ & $\begin{array}{l}0.100 * * \\
0.044\end{array}$ & $\begin{array}{c}-0.138 * * * \\
0.027\end{array}$ & $\begin{array}{r}-0.016 \\
0.023\end{array}$ & $\begin{array}{l}0.073 \\
0.053\end{array}$ & $\begin{array}{l}0.000 \\
0.019\end{array}$ & $\begin{array}{l}0.091 * * \\
0.036\end{array}$ & $\begin{array}{l}0.199 * \star \star \\
0.077\end{array}$ & $\begin{array}{c}-0.097 * \\
0.058\end{array}$ & $\begin{array}{l}0.198 * \star * \\
0.053\end{array}$ & $\begin{array}{l}0.074 * * \\
0.037\end{array}$ & $\begin{array}{l}0.151 * \star \star \\
0.049\end{array}$ & $\begin{array}{l}0.144 * \star \star \\
0.035\end{array}$ \\
\hline citizen & $\begin{array}{l}0.083 \\
0.055\end{array}$ & $\begin{array}{l}0.357 \text { * } \\
0.211\end{array}$ & $\begin{array}{l}0.238 * \star * \\
0.066\end{array}$ & $\begin{array}{c}-0.283 * \\
0.121\end{array}$ & $f(5)$ & $\begin{array}{l}0.263 * * \star \\
0.080\end{array}$ & $\begin{array}{r}-0.078 \\
0.098\end{array}$ & $\begin{array}{l}0.167 \\
0.106\end{array}$ & $\begin{array}{r}-0.059 \\
0.103\end{array}$ & $f(1)$ & $\begin{array}{l}0.264 * * \\
0.110\end{array}$ & $\begin{array}{r}-0.008 \\
0.219\end{array}$ & $\begin{array}{l}0.089 \\
0.181\end{array}$ & $\begin{array}{r}-0.235 \\
0.318\end{array}$ & $\begin{array}{l}0.032 \\
0.195\end{array}$ \\
\hline ethnic & $\begin{array}{c}-0.092 * \\
0.048\end{array}$ & $\begin{array}{l}0.055 \\
0.089\end{array}$ & $\begin{array}{c}-0.186 * \\
0.093\end{array}$ & $\begin{array}{l}0.195 \\
0.233\end{array}$ & $\begin{array}{r}-0.080 \\
0.130\end{array}$ & $\begin{array}{r}-0.214 \\
0.183\end{array}$ & $\begin{array}{l}0.001 \\
0.161\end{array}$ & $\begin{array}{l}-0.093 * \star * \\
0.027\end{array}$ & $\begin{array}{l}0.186 \\
0.342\end{array}$ & t & $\begin{array}{c}-0.302 \\
0.133\end{array}$ *夫 & $\begin{array}{l}0.073 \\
0.105\end{array}$ & $\mathrm{~s}(4)$ & $\begin{array}{l}0.388 \\
0.450\end{array}$ & $\begin{array}{r}-0.095 \\
0.082\end{array}$ \\
\hline fparent & $\begin{array}{l}-0.140 * * \star \\
0.043\end{array}$ & $\begin{array}{l}0.142 * * \\
0.051\end{array}$ & $\begin{array}{l}0.027 \\
0.055\end{array}$ & $\begin{array}{l}0.041 \\
0.120\end{array}$ & $\begin{array}{l}0.201 \text { ** } \\
0.073\end{array}$ & $\begin{array}{r}-0.058 \\
0.057\end{array}$ & $\begin{array}{l}-0.251 * * * \\
0.075\end{array}$ & $\begin{array}{c}-0.093 * \star * \\
0.041\end{array}$ & $\begin{array}{l}0.146 \\
0.102\end{array}$ & $\begin{array}{c}-0.438 * \\
0.138\end{array}$ & $\begin{array}{l}0.009 \\
0.100\end{array}$ & $\begin{array}{r}-0.057 \\
0.105\end{array}$ & $\begin{array}{r}-0.008 \\
0.182\end{array}$ & $\begin{array}{r}-0.077 \\
0.099\end{array}$ & $\begin{array}{l}-0.245 * * * \\
0.078\end{array}$ \\
\hline female & $\begin{array}{l}0.023 \\
0.018\end{array}$ & $\begin{array}{l}0.023 \\
0.049\end{array}$ & $\begin{array}{r}-0.038 \\
0.030\end{array}$ & $\begin{array}{r}-0.087 \\
0.066\end{array}$ & $\begin{array}{l}0.007 \\
0.049\end{array}$ & $\begin{array}{r}-0.021 \\
0.038\end{array}$ & $\begin{array}{l}0.093 * * \\
0.041\end{array}$ & $\begin{array}{r}-0.023 \\
0.023\end{array}$ & $\begin{array}{l}0.005 \\
0.043\end{array}$ & $\begin{array}{l}0.154 \text { ** } \\
0.073\end{array}$ & $\begin{array}{l}0.056 \\
0.082\end{array}$ & $\begin{array}{l}0.011 \\
0.059\end{array}$ & $\begin{array}{l}0.048 \\
0.051\end{array}$ & $\begin{array}{l}0.036 \\
0.059\end{array}$ & $\begin{array}{l}0.015 \\
0.044\end{array}$ \\
\hline age & $\begin{array}{l}0.001 * \\
0.000\end{array}$ & $\begin{array}{l}0.002 \\
0.002\end{array}$ & $\begin{array}{l}0.001 * * \\
0.000\end{array}$ & $\begin{array}{l}0.000 \\
0.003\end{array}$ & $\begin{array}{l}0.000 \\
0.002\end{array}$ & $\begin{array}{l}0.005 * * * \\
0.001\end{array}$ & $\begin{array}{l}0.002 \\
0.002\end{array}$ & $\begin{array}{l}0.001 * * \star \\
0.000\end{array}$ & $\begin{array}{c}-0.002 \\
0.001\end{array}$ & $\begin{array}{l}0.003 \\
0.004\end{array}$ & $\begin{array}{r}-0.001 \\
0.002\end{array}$ & $\begin{array}{c}-0.002 \text { * } \\
0.001\end{array}$ & $\begin{array}{l}0.005 * \star \star \\
0.001\end{array}$ & $\begin{array}{r}-0.002 \\
0.003\end{array}$ & $\begin{array}{l}0.000 \\
0.001\end{array}$ \\
\hline $\begin{array}{l}\text { log pseudoli keli hood } \\
\text { McFadden's (1974) LRI } \\
R^{2} \text { P } \\
\text { Sum of PCP }\end{array}$ & $\begin{array}{r}-3881.680 \\
0.095 \\
0.169 \\
1.279\end{array}$ & $\begin{array}{r}-198.120 \\
0.104 \\
0.071 \\
1.236\end{array}$ & $\begin{array}{r}-483.073 \\
0.051 \\
0.148 \\
1.193\end{array}$ & $\begin{array}{r}-140.281 \\
0.118 \\
0.142 \\
1.217\end{array}$ & $\begin{array}{r}-156.771 \\
0.074 \\
0.178 \\
1.254\end{array}$ & $\begin{array}{r}-381.804 \\
0.070 \\
0.066 \\
1.151\end{array}$ & $\begin{array}{r}-320.874 \\
0.104 \\
0.248 \\
1.290\end{array}$ & $\begin{array}{r}-340.813 \\
0.101 \\
-0.016 \\
1.047\end{array}$ & $\begin{array}{r}-338.247 \\
0.032 \\
0.023 \\
1.093\end{array}$ & $\begin{array}{r}-85.535 \\
0.171 \\
0.236 \\
1.267\end{array}$ & $\begin{array}{r}-143.813 \\
0.104 \\
0.100 \\
0.189\end{array}$ & $\begin{array}{r}-218.326 \\
0.065 \\
-0.023 \\
1.076\end{array}$ & $\begin{array}{r}-225.448 \\
0.105 \\
0.000 \\
1.119\end{array}$ & $\begin{array}{r}-118.934 \\
0.099 \\
0.052 \\
1.101\end{array}$ & $\begin{array}{r}-333.964 \\
0.121 \\
0.153 \\
1.257\end{array}$ \\
\hline obs. & 6311.000 & 375.000 & 735.000 & 231.000 & 259.000 & 656.000 & 519.000 & 1007.000 & 517.000 & 149.000 & 233.000 & 362.000 & 423.000 & 242.000 & 590.000 \\
\hline
\end{tabular}

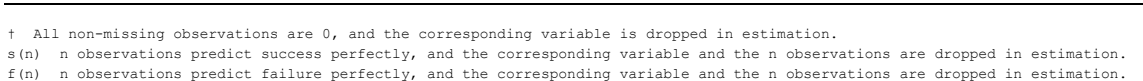

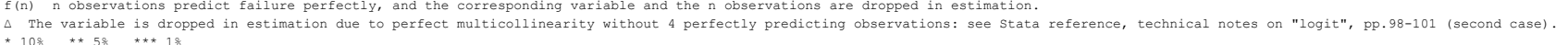

The three goodness-of-fit measures are described in verbeek (2004: 194-197). Sum of PCP is the sum of the proportions of correct predictions for anti $=1$ and anti $=0$.

Sampling weights provided by ESS are applied in maximum likelihood estimation.

Estimated standard errors are based on the assumption that observations are not necessarily independent within each region of a country, but are independent across regions of the country.

For EU, 13 country dumnies are included with UK being the reference. 
Table 7

(b) Probit estimates of marginal effects evaluated at the means of explanatory variables: those who did not think that immigration would depress wages on average

\begin{tabular}{|c|c|c|c|c|c|c|c|c|c|c|c|c|c|c|c|}
\hline & $\mathrm{EU}$ & RT & $\mathrm{DE}$ & $\mathrm{DK}$ & ES & EI & FR & GR & $\mathrm{IE}$ & IT & LU & NL & PT & $S E$ & UK \\
\hline employ & $\begin{array}{r}-0.005 \\
0.037\end{array}$ & $\begin{array}{r}-0.238 \\
0.214\end{array}$ & $\begin{array}{l}0.068 \\
0.055\end{array}$ & $\begin{array}{l}0.102 \\
0.116\end{array}$ & $\begin{array}{r}-0.127 \\
0.092\end{array}$ & $\begin{array}{l}0.196 \star \star \star \star \\
0.049\end{array}$ & $\begin{array}{l}0.019 \\
0.160\end{array}$ & $\begin{array}{l}0.089 \\
0.094\end{array}$ & $\begin{array}{l}0.118 \\
0.178\end{array}$ & $\begin{array}{l}0.042 \\
0.147\end{array}$ & $\begin{array}{l}0.362 \\
0.190\end{array}$ & $\begin{array}{l}0.202 \text { * } \\
0.124\end{array}$ & $\begin{array}{r}-0.018 \\
0.074\end{array}$ & $\begin{array}{l}0.1177^{* \star} \\
0.078\end{array}$ & $\begin{array}{r}-0.098 \\
0.141\end{array}$ \\
\hline employ $\mathrm{x}$ isb & $\begin{array}{l}0.045 \\
0.034\end{array}$ & $\begin{array}{r}-0.031 \\
0.211\end{array}$ & $\begin{array}{r}-0.062 \\
0.048\end{array}$ & $\begin{array}{r}-0.102 \\
0.105\end{array}$ & $\begin{array}{l}0.204 * * \star \\
0.069\end{array}$ & $\begin{array}{c}-0.206 * * \\
0.085\end{array}$ & $\begin{array}{r}-0.024 \\
0.102\end{array}$ & $\begin{array}{l}0.025 \\
0.056\end{array}$ & $\begin{array}{c}-0.070 \\
0.147\end{array}$ & $\begin{array}{l}0.024 \\
0.160\end{array}$ & $\begin{array}{r}-0.285 \\
0.225\end{array}$ & $\begin{array}{r}-0.111 \\
0.094\end{array}$ & $\begin{array}{l}0.031 \\
0.044\end{array}$ & $\begin{array}{c}-0.032 \\
0.038\end{array}$ & $\begin{array}{l}0.218 \\
0.159\end{array}$ \\
\hline unemploy & $\begin{array}{l}0.069 \\
0.069\end{array}$ & $\begin{array}{r}-0.463 \\
0.254\end{array}$ & $\begin{array}{l}0.399 * \star \star \\
0.089\end{array}$ & $\begin{array}{r}-0.144 \\
0.136\end{array}$ & $\begin{array}{l}0.248 * \star \\
0.095\end{array}$ & $\begin{array}{l}0.150 \\
0.182\end{array}$ & $\begin{array}{c}-0.027 \\
0.174\end{array}$ & $\begin{array}{l}-0.439 * * \\
0.132\end{array}$ & $\begin{array}{r}-0.144 \\
0.085\end{array}$ & $\begin{array}{c}-0.049 \\
0.168\end{array}$ & $\begin{array}{l}0.485 \\
0.604\end{array}$ & $\begin{array}{c}-0.237 \text { * } \\
0.082\end{array}$ & $\begin{array}{r}-0.311 \\
0.222\end{array}$ & $\begin{array}{r}-0.070 \\
0.031\end{array}$ & $\begin{array}{l}0.703 \text { ** } \\
0.067\end{array}$ \\
\hline unemploy $\times$ isb & $\begin{array}{r}-0.050 \\
0.041\end{array}$ & $\begin{array}{l}0.568 \\
0.618\end{array}$ & $\begin{array}{c}-0.223 * * \star \\
0.041\end{array}$ & $\begin{array}{l}0.092 \\
0.100\end{array}$ & $\begin{array}{c}-0.267 * * * \\
0.102\end{array}$ & $\begin{array}{r}-0.092 \\
0.174\end{array}$ & $\begin{array}{l}0.062 \\
0.089\end{array}$ & $\begin{array}{l}0.446 * \star \star \\
0.130\end{array}$ & $\begin{array}{l}0.125 \\
0.144\end{array}$ & $\begin{array}{l}0.057 \\
0.148\end{array}$ & $\begin{array}{r}-0.891 \\
1.302\end{array}$ & $\begin{array}{l}0.107 \\
0.147\end{array}$ & $\begin{array}{l}0.198 \\
0.2204\end{array}$ & $\begin{array}{l}0.124 \\
0.076\end{array}$ & $\begin{array}{c}-1.188 * * \\
0.466\end{array}$ \\
\hline$i s b$ & $\begin{array}{r}-0.011 \\
0.014\end{array}$ & $\begin{array}{l}0.049 \\
0.071\end{array}$ & $\begin{array}{l}0.098 * \star \star \star \\
0.023\end{array}$ & $\begin{array}{l}0.022 \\
0.050\end{array}$ & $\begin{array}{c}-0.074 * \star \\
0.032\end{array}$ & $\begin{array}{c}-0.029 * * \\
0.015\end{array}$ & $\begin{array}{r}-0.003 \\
0.027\end{array}$ & $\begin{array}{r}-0.015 \\
0.015\end{array}$ & $\begin{array}{l}0.003 \\
0.037\end{array}$ & $\begin{array}{r}-0.116 \\
0.088\end{array}$ & $\begin{array}{l}0.209 \star * \star \\
0.091\end{array}$ & $\begin{array}{l}0.046 \text { * } \\
0.025\end{array}$ & $\begin{array}{r}-0.089 \\
0.056\end{array}$ & $\begin{array}{r}-0.013 \\
0.020\end{array}$ & $\begin{array}{c}-0.120 * * \\
0.049\end{array}$ \\
\hline relinc & $\begin{array}{r}-0.008 \\
0.005\end{array}$ & $\begin{array}{r}-0.006 \\
0.033\end{array}$ & $\begin{array}{l}0.001 \\
0.008\end{array}$ & $\begin{array}{r}-0.024 \\
0.029\end{array}$ & $\begin{array}{r}-0.024 \\
0.038\end{array}$ & $\begin{array}{l}0.016 \text { * } \\
0.009\end{array}$ & $\begin{array}{r}-0.018 \\
0.017\end{array}$ & $\begin{array}{r}-0.028 \\
0.018\end{array}$ & $\begin{array}{l}0.003 \\
0.019\end{array}$ & $\begin{array}{r}-0.027 \\
0.025\end{array}$ & $\begin{array}{l}0.043 \\
0.047\end{array}$ & $\begin{array}{r}-0.011 \\
0.018\end{array}$ & $\begin{array}{r}-0.026 \\
0.016\end{array}$ & $\begin{array}{r}-0.010 \\
0.011\end{array}$ & $\begin{array}{c}-0.002 \\
0.013\end{array}$ \\
\hline$e d 0$ & $\begin{array}{l}0.066 \\
0.052\end{array}$ & $\begin{array}{l}0.167 \\
0.293\end{array}$ & t & $\mathrm{s}(1)$ & $\begin{array}{l}0.012 \\
0.134\end{array}$ & $\begin{array}{l}0.205 \\
0.171\end{array}$ & $\begin{array}{l}0.118 \\
0.088\end{array}$ & $\begin{array}{r}-0.032 \\
0.132\end{array}$ & $\begin{array}{l}0.223 \text { ** } \\
0.115\end{array}$ & $\begin{array}{l}0.249 \\
0.346\end{array}$ & $f(1)$ & $\begin{array}{r}-0.129 \\
0.151\end{array}$ & $\begin{array}{l}0.277 *^{*} \\
0.133\end{array}$ & $f(8)$ & + \\
\hline edI & $\begin{array}{l}0.080 * \star \star \\
0.018\end{array}$ & $\begin{array}{l}0.030 \\
0.037\end{array}$ & $\begin{array}{l}0.060 \\
0.039\end{array}$ & $\begin{array}{l}0.067 \\
0.042\end{array}$ & $\begin{array}{r}-0.008 \\
0.068\end{array}$ & $\begin{array}{l}0.022 \\
0.042\end{array}$ & $\begin{array}{l}0.122 * \star \\
0.055\end{array}$ & $\begin{array}{l}0.072 \\
0.077\end{array}$ & $\begin{array}{l}0.057 \text { * } \\
0.031\end{array}$ & $\begin{array}{l}0.210 * \star \star \\
0.051\end{array}$ & $\begin{array}{l}0.083 \\
0.077\end{array}$ & $\begin{array}{l}0.022 \\
0.044\end{array}$ & $\begin{array}{l}0.052 \\
0.039\end{array}$ & $\begin{array}{l}0.025 * \star \\
0.012\end{array}$ & $\begin{array}{l}0.107 * \star * \\
0.033\end{array}$ \\
\hline$e d 3$ & $\begin{array}{l}-0.080 * \star \star \star \\
0.019\end{array}$ & $\begin{array}{r}-0.050 \\
0.051\end{array}$ & $\begin{array}{c}-0.095 * * \star \\
0.029\end{array}$ & $\begin{array}{c}-0.149 * \star \star \star \\
0.042\end{array}$ & $\begin{array}{l}0.064 \\
0.087\end{array}$ & $\begin{array}{c}-0.103 * * \\
0.049\end{array}$ & $\begin{array}{r}-0.022 \\
0.048\end{array}$ & $\begin{array}{c}-0.095 * * \\
0.046\end{array}$ & $\begin{array}{c}-0.074 * \star \\
0.026\end{array}$ & $\begin{array}{l}0.024 \\
0.112\end{array}$ & $\begin{array}{r}-0.055 \\
0.088\end{array}$ & $\begin{array}{c}-0.153 * * \star \\
0.030\end{array}$ & $\begin{array}{l}0.042 \\
0.098\end{array}$ & $\begin{array}{l}-0.047 * * * \\
0.005\end{array}$ & $\begin{array}{c}-0.149 * \star \star \star \\
0.041\end{array}$ \\
\hline media & $\begin{array}{c}-0.016 \text { ** } \\
0.007\end{array}$ & $\begin{array}{l}0.000 \\
0.023\end{array}$ & $\begin{array}{c}-0.029 * * \\
0.011\end{array}$ & $\begin{array}{c}-0.028 * \star \\
0.013\end{array}$ & $\begin{array}{l}0.021 \\
0.023\end{array}$ & $\begin{array}{l}0.012 \\
0.016\end{array}$ & $\begin{array}{c}-0.037 * \\
0.021\end{array}$ & $\begin{array}{c}-0.080 * * \\
0.037\end{array}$ & $\begin{array}{r}-0.017 \\
0.013\end{array}$ & $\begin{array}{l}0.049 * \star \\
0.021\end{array}$ & $\begin{array}{r}-0.024 \\
0.022\end{array}$ & $\begin{array}{l}0.012 \\
0.010\end{array}$ & $\begin{array}{r}-0.010 \\
0.027\end{array}$ & $\begin{array}{l}0.000 \\
0.004\end{array}$ & $\begin{array}{c}-0.047 * * * \\
0.014\end{array}$ \\
\hline friend 1 & $\begin{array}{c}-0.085 * \star \star \star \\
0.014\end{array}$ & $\begin{array}{l}-0.208 * \star \star \\
0.041\end{array}$ & $\begin{array}{l}-0.099 * \star \star \\
0.020\end{array}$ & $\begin{array}{l}-0.127 * \star \star \\
0.031\end{array}$ & $\begin{array}{l}-0.126 * \star \star \star \\
0.047\end{array}$ & $\begin{array}{l}-0.095 * \star \\
0.040\end{array}$ & $\begin{array}{c}-0.074 * \\
0.040\end{array}$ & $\begin{array}{l}-0.224 * \star \star \\
0.084\end{array}$ & $\begin{array}{r}-0.016 \\
0.029\end{array}$ & $\begin{array}{r}-0.072 \\
0.049\end{array}$ & $\begin{array}{l}0.025 \\
0.091\end{array}$ & $\begin{array}{l}-0.068 * \star \star \\
0.025\end{array}$ & $\begin{array}{r}-0.045 \\
0.102\end{array}$ & $\begin{array}{r}-0.001 \\
0.020\end{array}$ & $\begin{array}{l}-0.079 \text { ** } \\
0.032\end{array}$ \\
\hline friend 2 & $\begin{array}{l}-0.179 * \star \star \\
0.018\end{array}$ & $\begin{array}{l}-0.299 * * * \\
0.035\end{array}$ & $\begin{array}{c}-0.170 * * * \\
0.043\end{array}$ & $\begin{array}{c}-0.245 * \star \star \star \\
0.077\end{array}$ & $\begin{array}{c}-0.327 * * \star \\
0.061\end{array}$ & $\begin{array}{c}-0.351 * * \star \\
0.017\end{array}$ & $\begin{array}{c}-0.214 * \star \star \\
0.031\end{array}$ & $\begin{array}{c}-0.194 * \star \\
0.092\end{array}$ & $\begin{array}{l}-0.119 * * \star \\
0.015\end{array}$ & $\begin{array}{r}-0.185 \\
0.047\end{array}$ & $\begin{array}{l}0.076 \\
0.087\end{array}$ & $\begin{array}{c}-0.068 * \\
0.035\end{array}$ & $\begin{array}{c}-0.222 * * * \star \\
0.046\end{array}$ & $\begin{array}{c}-0.044 * * * \\
0.014\end{array}$ & $\begin{array}{c}-0.110 \star \star \\
0.045\end{array}$ \\
\hline racist & $\begin{array}{l}0.140 * * \star \\
0.015\end{array}$ & $\begin{array}{l}0.002 \\
0.020\end{array}$ & $\begin{array}{l}0.118 * * * \\
0.031\end{array}$ & $\begin{array}{l}0.128 * \star * \\
0.028\end{array}$ & $\begin{array}{l}0.131 * * * \\
0.040\end{array}$ & $\begin{array}{l}0.034 \\
0.033\end{array}$ & $\begin{array}{l}0.170 * \star \star \\
0.035\end{array}$ & $\begin{array}{l}0.143 * \\
0.074\end{array}$ & $\begin{array}{l}0.104 * \star \star \\
0.032\end{array}$ & $\begin{array}{l}0.115 * * \\
0.054\end{array}$ & $\begin{array}{l}0.045 \\
0.055\end{array}$ & $\begin{array}{l}0.125 * * * \\
0.037\end{array}$ & $\begin{array}{l}0.155 * * \\
0.076\end{array}$ & $\begin{array}{l}0.093 * \star \star \\
0.012\end{array}$ & $\begin{array}{l}0.223 * * * \\
0.041\end{array}$ \\
\hline citizen & $\begin{array}{l}0.065 * \\
0.033\end{array}$ & $\begin{array}{r}-0.188 \\
0.126\end{array}$ & $\begin{array}{l}0.094 \text { * } \\
0.045\end{array}$ & $\begin{array}{l}0.181 \\
0.106\end{array}$ & $\begin{array}{l}0.085 * * \\
0.159\end{array}$ & $\begin{array}{l}0.025 \\
0.141\end{array}$ & $\begin{array}{r}-0.063 \\
0.118\end{array}$ & $\begin{array}{l}0.231 * \star \\
0.104\end{array}$ & $\begin{array}{l}0.158 * \star \star \\
0.030\end{array}$ & $\neq$ & $\begin{array}{r}-0.099 \\
0.106\end{array}$ & $\begin{array}{r}-0.085 \\
0.123\end{array}$ & $\begin{array}{l}0.072 \\
0.157\end{array}$ & $\begin{array}{r}-0.011 \\
0.033\end{array}$ & $\begin{array}{l}0.151 \\
0.088\end{array}$ \\
\hline ethric & $\begin{array}{l}0.070 \\
0.045\end{array}$ & $\begin{array}{l}0.132 * * \\
0.060\end{array}$ & $\begin{array}{r}-0.041 \\
0.095\end{array}$ & $\begin{array}{l}0.136 \\
0.133\end{array}$ & $f(9)$ & $\mathrm{f}(5)$ & $\begin{array}{l}0.108 \\
0.116\end{array}$ & $\begin{array}{r}-0.068 \\
0.142\end{array}$ & $\begin{array}{c}-0.164 \text { * } \\
0.047\end{array}$ & $\begin{array}{l}0.601 * * \\
0.235\end{array}$ & $\begin{array}{r}-0.099 \\
0.141\end{array}$ & $\begin{array}{l}0.055 \\
0.061\end{array}$ & $\begin{array}{r}-0.148 \\
0.157\end{array}$ & $\begin{array}{r}-0.007 \\
0.048\end{array}$ & $\begin{array}{l}0.119 \\
0.106\end{array}$ \\
\hline fparent & $\begin{array}{l}0.007 \\
0.019\end{array}$ & $\begin{array}{r}-0.037 \\
0.034\end{array}$ & $\begin{array}{l}0.033 \\
0.046\end{array}$ & $\begin{array}{l}0.017 \\
0.069\end{array}$ & $\begin{array}{r}-0.061 \\
0.125\end{array}$ & $\begin{array}{l}0.190 * \star \\
0.081\end{array}$ & $\begin{array}{r}-0.023 \\
0.028\end{array}$ & $\begin{array}{r}-0.013 \\
0.077\end{array}$ & $\begin{array}{l}0.068 \\
0.066\end{array}$ & $\begin{array}{r}-0.122 \\
0.073\end{array}$ & $\begin{array}{c}-0.156 * \\
0.085\end{array}$ & $\begin{array}{c}-0.086 \text { ** } \\
0.039\end{array}$ & $\begin{array}{r}-0.139 \\
0.168\end{array}$ & $\begin{array}{l}0.048 \text { * } \\
0.032\end{array}$ & $\begin{array}{l}0.037 \\
0.059\end{array}$ \\
\hline female & $\begin{array}{r}-0.008 \\
0.013\end{array}$ & $\begin{array}{l}0.001 \\
0.035\end{array}$ & $\begin{array}{r}-0.033 \\
0.020\end{array}$ & $\begin{array}{r}-0.037 \\
0.040\end{array}$ & $\begin{array}{l}0.035 \\
0.046\end{array}$ & $\begin{array}{l}-0.119 * \star \star \\
0.027\end{array}$ & $\begin{array}{l}0.001 \\
0.052\end{array}$ & $\begin{array}{c}-0.119 * \\
0.065\end{array}$ & $\begin{array}{l}-0.071 \text { * } \\
0.026\end{array}$ & $\begin{array}{l}0.015 \\
0.053\end{array}$ & $\begin{array}{r}-0.007 \\
0.063\end{array}$ & $\begin{array}{r}-0.021 \\
0.026\end{array}$ & $\begin{array}{l}0.079 \\
0.076\end{array}$ & $\begin{array}{c}-0.035 \text { ** } \\
0.016\end{array}$ & $\begin{array}{l}0.018 \\
0.024\end{array}$ \\
\hline age & $\begin{array}{l}0.001 * * \\
0.000\end{array}$ & $\begin{array}{l}0.006 * * \\
0.002\end{array}$ & $\begin{array}{l}0.001 \\
0.001\end{array}$ & $\begin{array}{l}0.004 * \star \star \star \\
0.001\end{array}$ & $\begin{array}{r}-0.001 \\
0.002\end{array}$ & $\begin{array}{l}0.008 * \star \star \\
0.001\end{array}$ & $\begin{array}{l}0.003 * \\
0.001\end{array}$ & $\begin{array}{l}0.001 \\
0.002\end{array}$ & $\begin{array}{l}0.000 \\
0.000\end{array}$ & $\begin{array}{r}-0.002 \\
0.002\end{array}$ & $\begin{array}{l}0.002 \\
0.002\end{array}$ & $\begin{array}{l}0.000 \\
0.000\end{array}$ & $\begin{array}{l}0.000 \\
0.002\end{array}$ & $\begin{array}{l}0.000 \\
0.000\end{array}$ & $\begin{array}{l}0.000 \\
0.000\end{array}$ \\
\hline $\begin{array}{l}\text { log pseudoli ikelihood } \\
\text { McFadden's (1974) LRI } \\
R^{2} \text { P } \\
\text { Sum of PCP }\end{array}$ & $\begin{array}{r}-5904.455 \\
0.095 \\
0.110 \\
1.220\end{array}$ & $\begin{array}{r}-414.197 \\
0.115 \\
0.291 \\
1.341\end{array}$ & $\begin{array}{r}-597.226 \\
0.090 \\
0.035 \\
1.112\end{array}$ & $\begin{array}{r}-558.850 \\
0.086 \\
0.163 \\
1.243\end{array}$ & $\begin{array}{r}-260.502 \\
0.089 \\
0.081 \\
1.177\end{array}$ & $\begin{array}{r}-585.576 \\
0.141 \\
0.289 \\
1.339\end{array}$ & $\begin{array}{r}-311.356 \\
0.117 \\
0.124 \\
1.232\end{array}$ & $\begin{array}{r}-146.029 \\
0.138 \\
0.185 \\
1.255\end{array}$ & $\begin{array}{r}-422.739 \\
0.074 \\
0.051 \\
1.077\end{array}$ & $\begin{array}{r}-148.411 \\
0.102 \\
0.057 \\
1.089\end{array}$ & $\begin{array}{r}-202.009 \\
0.062 \\
0.051 \\
1.139\end{array}$ & $\begin{array}{r}-851.886 \\
0.044 \\
-0.006 \\
1.038\end{array}$ & $\begin{array}{r}-237.864 \\
0.089 \\
0.163 \\
1.190\end{array}$ & $\begin{array}{r}-402.822 \\
0.101 \\
0.028 \\
1.041\end{array}$ & $\begin{array}{r}-573.789 \\
0.137 \\
0.165 \\
1.257\end{array}$ \\
\hline obs. & 10657.000 & 677.000 & 1148.000 & 901.000 & 423.000 & 989.000 & 582.000 & 248.000 & 856.000 & 313.000 & 316.000 & 1406.000 & 379.000 & 1356.000 & 1039.000 \\
\hline
\end{tabular}

f A11 non-missing observations are 0 , and the corresponding variable is dropped in estimation.
f A11 non-missing observations are 1 , and the corresponding variable is dropped in estimation.

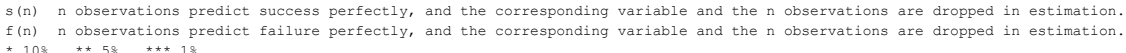

The three goodness-of-fit measures are described in Verbeek (2004: 194-197). Sum of PCP is the sum of the proportions of correct predictions for anti $=1$ and anti $=0$.

Sampling weights provided by ESS are applied in maximum likelihood estimation.
For EU, a further weight adjustment is made to reflect the population size of

Estimated standard errors are based on the assumption that observations are not necessarily independent within each region of a country, but are independent across regions of the country.

For EU, 13 country dunnies are included with UK being the reference. 
Table 8

Probit estimates of the effects of employ and unemploy evaluated at the means of explanatory variables: re-estimating the EU equation in Table 4 (excluding isb) sector by sector

\begin{tabular}{|c|c|c|c|c|c|c|c|c|c|c|c|c|c|c|c|}
\hline & \multicolumn{3}{|c|}{ a. agriculture, hunting, forestry } & \multicolumn{3}{|c|}{ d. manufacturing } & \multicolumn{3}{|c|}{ e. electricity, gas, water supply } & \multicolumn{3}{|l|}{ f. construction } & \multicolumn{3}{|c|}{$\begin{array}{l}\text { g. wholesale/retail trade, repair of motor } \\
\text { vehicles and personal/household goods }\end{array}$} \\
\hline & i & ii & $\mathrm{iiii}$ & i & $i_{i i}$ & $i_{i i \mathrm{i}}$ & i & ii & $\mathrm{iii}_{\mathrm{i}}$ & i & ii & iii & i & $\mathrm{ii}_{\mathrm{i}}$ & $i_{i i \mathrm{i}}$ \\
\hline employ & $\begin{array}{r}-0.046 \\
0.064\end{array}$ & $\begin{array}{r}-0.108 \\
0.069\end{array}$ & $\begin{array}{r}-0.042 \\
0.080\end{array}$ & $\begin{array}{r}-0.018 \\
0.059\end{array}$ & $\begin{array}{r}-0.020 \\
0.113\end{array}$ & $\begin{array}{l}0.004 \\
0.076\end{array}$ & $\begin{array}{l}0.250 \\
0.234\end{array}$ & $\begin{array}{r}-0.207 \\
0.152\end{array}$ & $s(2)$ & $\begin{array}{l}0.060 \\
0.056\end{array}$ & $\begin{array}{l}0.028 \\
0.094\end{array}$ & $\begin{array}{l}0.148 * * \\
0.068\end{array}$ & $\begin{array}{l}0.033 \\
0.042\end{array}$ & $\begin{array}{c}-0.012 \\
0.077\end{array}$ & $\begin{array}{l}0.095 * \\
0.055\end{array}$ \\
\hline unemploy & $\begin{array}{r}-0.046 \\
0.093\end{array}$ & $\begin{array}{l}0.063 \\
0.095\end{array}$ & $\begin{array}{l}-0.302 * * * \\
0.057\end{array}$ & $\begin{array}{l}0.091 * \\
0.052\end{array}$ & $\begin{array}{l}0.166 * * \\
0.071\end{array}$ & $\begin{array}{r}-0.001 \\
0.076\end{array}$ & $\begin{array}{l}0.102 \\
0.262\end{array}$ & $f(1)$ & $\begin{array}{l}0.297 * \\
0.210^{*}\end{array}$ & $\begin{array}{l}0.174 * \star \\
0.074\end{array}$ & $\begin{array}{l}0.039 \\
0.105\end{array}$ & $\begin{array}{l}0.283 * * \\
0.119\end{array}$ & $\begin{array}{l}0.081 \\
0.050\end{array}$ & $\begin{array}{r}-0.010 \\
0.086\end{array}$ & $\begin{array}{l}0.100 \\
0.108\end{array}$ \\
\hline $\begin{array}{l}\text { log pseudolikeli hood } \\
\text { McFadden's (1974) LRI } \\
R^{2} \text { p } \\
\text { Sum of PCP }\end{array}$ & $\begin{array}{r}-597.292 \\
0.126 \\
0.233 \\
1.368\end{array}$ & $\begin{array}{r}-239.651 \\
0.174 \\
0.068 \\
1.276\end{array}$ & $\begin{array}{r}-231.929 \\
0.172 \\
0.313 \\
1.346\end{array}$ & $\begin{array}{r}-2160.335 \\
0.097 \\
0.292 \\
1.312\end{array}$ & $\begin{array}{r}-849.757 \\
0.102 \\
0.169 \\
1.271\end{array}$ & $\begin{array}{r}-1165.849 \\
0.088 \\
0.127 \\
1.232\end{array}$ & $\begin{array}{r}-78.528 \\
0.308 \\
0.294 \\
1.365\end{array}$ & $\begin{array}{r}-17.108 \\
0.555 \\
0.480 \\
1.564\end{array}$ & $\begin{array}{r}-28.937 \\
0.478 \\
0.233 \\
1.416\end{array}$ & $\begin{array}{r}-765.825 \\
0.120 \\
0.267 \\
1.310\end{array}$ & $\begin{array}{r}-319.064 \\
0.136 \\
0.101 \\
1.224\end{array}$ & $\begin{array}{r}-363.602 \\
0.147 \\
0.221 \\
1.291\end{array}$ & $\begin{array}{r}-1504.710 \\
0.116 \\
0.303 \\
1.334\end{array}$ & $\begin{array}{r}-553.108 \\
0.117 \\
0.119 \\
1.255\end{array}$ & $\begin{array}{r}-820.300 \\
0.119 \\
0.123 \\
1.233\end{array}$ \\
\hline \multirow[t]{3}{*}{ obs. } & 990.000 & 486.000 & 435.000 & 3472.000 & 1389.000 & 1956.000 & 177.000 & 58.000 & 90.000 & 1257.000 & 567.000 & 656.000 & 2489.000 & 926.000 & 1476.000 \\
\hline & \multicolumn{3}{|c|}{ h. hotels, restaurants } & \multicolumn{3}{|c|}{ i. transport, storage, communication } & \multicolumn{3}{|c|}{$j$. financial intermediation } & \multicolumn{3}{|c|}{$\begin{array}{l}\text { k. real estate/renting/business } \\
\text { activities }\end{array}$} & \multicolumn{3}{|c|}{$\begin{array}{l}\text { 1. public administration, defence, } \\
\text { compulsory social security }\end{array}$} \\
\hline & i & ii & $i_{i i i}$ & i & $i_{i i}$ & $\mathrm{iiii}$ & $i$ & $i_{i i}$ & $\mathrm{i} i \mathrm{ii}_{\mathrm{s}}$ & i & ii & $i_{i i \mathrm{i}}$ & i & ii & $i_{i i \mathrm{i}}$ \\
\hline employ & $\begin{array}{l}0.103 \\
0.088\end{array}$ & $\begin{array}{l}0.286 * * \\
0.086\end{array}$ & $\begin{array}{l}0.038 \\
0.078\end{array}$ & $\begin{array}{l}0.019 \\
0.076\end{array}$ & $\begin{array}{r}-0.072 \\
0.153\end{array}$ & $\begin{array}{l}0.093 \\
0.090\end{array}$ & $\begin{array}{l}0.125 \\
0.139\end{array}$ & $\begin{array}{l}0.260 \\
0.221\end{array}$ & $\begin{array}{l}0.074 \\
0.120\end{array}$ & $\begin{array}{r}-0.019 \\
0.055\end{array}$ & $\begin{array}{l}0.054 \\
0.103\end{array}$ & $\begin{array}{r}-0.033 \\
0.059\end{array}$ & $\begin{array}{r}-0.076 \\
0.135\end{array}$ & $s(1)$ & $\begin{array}{l}0.059 \\
0.152\end{array}$ \\
\hline unemploy & $\begin{array}{r}-0.060 \\
0.072\end{array}$ & $\begin{array}{l}0.121 \\
0.123\end{array}$ & $\begin{array}{l}-0.201 * * * \\
0.043\end{array}$ & $\begin{array}{r}-0.079 \\
0.108\end{array}$ & $\begin{array}{r}-0.156 \\
0.151\end{array}$ & $\begin{array}{l}0.011 \\
0.118\end{array}$ & $\begin{array}{r}-0.097 \\
0.145\end{array}$ & $\begin{array}{l}0.389 * \star \star \\
0.067\end{array}$ & $\begin{array}{l}-0.225 * * \\
0.058\end{array}$ & $\begin{array}{l}0.079 \\
0.087\end{array}$ & $\begin{array}{l}0.220 * * \\
0.092\end{array}$ & $\begin{array}{l}0.015 \\
0.093\end{array}$ & $\begin{array}{l}0.395 * \star \star \\
0.097\end{array}$ & $\begin{array}{l}0.233 \\
0.110\end{array}$ & $\begin{array}{l}0.476 * * \star \\
0.142\end{array}$ \\
\hline $\begin{array}{l}\text { log pseudolikelihood } \\
\text { McFadden's (1974) LRI } \\
R^{2} \text { P } \\
\text { Sum of PCP }\end{array}$ & $\begin{array}{r}-393.957 \\
0.256 \\
0.388 \\
1.429\end{array}$ & $\begin{array}{r}-130.113 \\
0.342 \\
0.272 \\
1.443\end{array}$ & $\begin{array}{r}-188.073 \\
0.263 \\
0.166 \\
1.346\end{array}$ & $\begin{array}{r}-741.708 \\
0.117 \\
0.318 \\
1.344\end{array}$ & $\begin{array}{r}-268.944 \\
0.160 \\
0.215 \\
1.352\end{array}$ & $\begin{array}{r}-415.953 \\
0.100 \\
0.186 \\
1.271\end{array}$ & $\begin{array}{r}-319.518 \\
0.153 \\
0.255 \\
1.333\end{array}$ & $\begin{array}{r}-97.736 \\
0.209 \\
0.217 \\
1.301\end{array}$ & $\begin{array}{r}-182.221 \\
0.160 \\
0.184 \\
1.297\end{array}$ & $\begin{array}{r}-927.933 \\
0.150 \\
0.149 \\
1.287\end{array}$ & $\begin{array}{r}-239.084 \\
0.197 \\
0.386 \\
1.391\end{array}$ & $\begin{array}{r}-614.894 \\
0.153 \\
0.041 \\
1.213\end{array}$ & $\begin{array}{r}-730.022 \\
0.139 \\
0.334 \\
1.386\end{array}$ & $\begin{array}{r}-238.851 \\
0.148 \\
0.166 \\
1.334\end{array}$ & $\begin{array}{r}-401.225 \\
0.137 \\
0.156 \\
1.282\end{array}$ \\
\hline obs. & 784.000 & 296.000 & 437.000 & 1229.000 & 469.000 & 722.000 & 575.000 & 181.000 & 370.000 & 1693.000 & 434.000 & 1200.000 & 1255.000 & 423.000 & 783.000 \\
\hline
\end{tabular}

m. education $\quad$ n. health/socia1 work $\quad$ o. other community/social/personal service

\begin{tabular}{|c|c|c|c|c|c|c|c|c|c|c|c|c|}
\hline \multirow[b]{3}{*}{ employ } & & & & & & & & & & \\
\hline & i & ii & iii & i & ii & iii & $i$ & ii & $\overline{i i \mathrm{i}}$ & i & $\mathrm{ii}$ & ${ }^{i j i}$ \\
\hline & $\begin{array}{l}0.076 \\
0.091\end{array}$ & $\begin{array}{r}-0.082 \\
0.171\end{array}$ & $\begin{array}{l}0.133 \\
0.122\end{array}$ & $\begin{array}{l}0.002 \\
0.086\end{array}$ & $\begin{array}{r}-0.147 \\
0.191\end{array}$ & $\begin{array}{l}0.034 \\
0.079\end{array}$ & $\begin{array}{r}-0.015 \\
0.086\end{array}$ & $\begin{array}{c}-0.293 * * \\
0.124\end{array}$ & $\begin{array}{l}0.017 \\
0.080\end{array}$ & $\begin{array}{l}0.260 * \\
0.120\end{array}$ & $\begin{array}{l}0.245 * \star \star \\
0.063\end{array}$ & $\begin{array}{l}0.414 * \star \star \\
0.178\end{array}$ \\
\hline unemp 1oy & $\begin{array}{l}0.164 \\
0.117\end{array}$ & $\begin{array}{l}0.355 * * \\
0.127\end{array}$ & $\begin{array}{r}-0.047 \\
0.103\end{array}$ & $\begin{array}{r}-0.062 \\
0.090\end{array}$ & $\begin{array}{r}-0.086 \\
0.144\end{array}$ & $\begin{array}{r}-0.116 \\
0.061\end{array}$ & $\begin{array}{l}0.020 \\
0.095\end{array}$ & $\begin{array}{r}-0.168 \\
0.143\end{array}$ & $\begin{array}{r}-0.018 \\
0.138\end{array}$ & $\begin{array}{c}-0.332 \text { * } \\
0.132\end{array}$ & $\begin{array}{c}-0.682 \star \star \star \star \\
0.102\end{array}$ & $f(5)$ \\
\hline 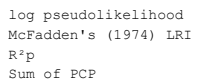 & $\begin{array}{r}-761.198 \\
0.134 \\
0.113 \\
1.246\end{array}$ & $\begin{array}{r}-209.113 \\
0.159 \\
0.280 \\
1.286\end{array}$ & $\begin{array}{r}-454.197 \\
0.159 \\
-0.012 \\
1.136\end{array}$ & $\begin{array}{r}-1181.794 \\
0.123 \\
0.102 \\
1.233\end{array}$ & $\begin{array}{r}-288.439 \\
0.182 \\
0.211 \\
1.269\end{array}$ & $\begin{array}{r}-737.163 \\
0.133 \\
0.027 \\
1.159\end{array}$ & $\begin{array}{r}-542.175 \\
0.186 \\
0.250 \\
1.345\end{array}$ & $\begin{array}{r}-133.208 \\
0.318 \\
0.210 \\
1.338\end{array}$ & $\begin{array}{r}-314.110 \\
0.212 \\
0.181 \\
1.339\end{array}$ & $\begin{array}{r}-132.186 \\
0.159 \\
0.200 \\
1.217\end{array}$ & $\begin{array}{r}-61.373 \\
0.212 \\
-0.1100 \\
1.111\end{array}$ & $\begin{array}{r}-20.440 \\
0.5535 \\
0.260 \\
1.445\end{array}$ \\
\hline obs, & 1493.000 & 359,000 & 1070,000 & 2108,000 & 510,000 & 1501.000 & 988.000 & 295,000 & 647.000 & 227.000 & 125,000 & 72,000 \\
\hline
\end{tabular}

1493.000
obs.

$\begin{array}{ll}s(n) & n \text { observations predict success perfectly, and the corresponding variable and the } n \text { observations are dropped in estimation. } \\ f(n) & n \text { observations predict failure perfectry, and the corresponding variable and the } n \text { observations are dropped in estimation. }\end{array}$

$* 108 \quad *+58 \quad *+* 18$

Categories b (fishing) and c (mining, quarrying) are omitted due to the small number of observations.

The three goodness-of-fit measures are described in verbeek (2004: 194-197). Sum of PCP is the sum of the proportions of correct predictions for anti $=1$ and anti $=0$.

Sampling weights provided by ESS are applied in maximum 1ikelihood estimation. The adjustment reflects the population size of each country.

Tstimated standard errors are based on the assumption that observations are not necessarily independent within each region of a country, but are independent across regions of the country.

14 country dunnies are included with UK being the reference. (NBB: Belgium is included because isb is not used.)

The full results are available from the author upon request. 